\title{
OPEN EDUCATIONAL RESOURCES: MOTIVATIONS, GOVERNANCE, AND CONTENT PROTECTION
}

\author{
by
}

Mónica Joana Mora

\begin{abstract}
A thesis submitted to the Faculty of Graduate Studies and Research in partial fulfillment of the requirements for the degree of Master of Applied Science in Technology Innovation Management
\end{abstract}

\author{
Department of Systems and Computer Engineering \\ Carleton University \\ Ottawa, Canada, K1S 5B6
}

August, 2008

(C) Copyright 2008 Mónica Joana Mora 


$\begin{array}{ll}\begin{array}{l}\text { Library and } \\ \text { Archives Canada }\end{array} & \begin{array}{l}\text { Bibliothèque et } \\ \text { Archives Canada }\end{array} \\ \begin{array}{l}\text { Published Heritage } \\ \text { Branch }\end{array} & \begin{array}{l}\text { Direction du } \\ \text { Patrimoine de l'édition }\end{array} \\ \begin{array}{l}\text { 395 Wellington Street } \\ \text { Ottawa ON K1A 0N4 } \\ \text { Canada }\end{array} & \begin{array}{l}\text { 395, rue Wellington } \\ \text { Ottawa ON K1A 0N4 } \\ \text { Canada }\end{array}\end{array}$

Your file Votre référence ISBN: 978-0-494-44054-4 Ourfile Notre référence ISBN: 978-0-494-44054-4

NOTICE:

The author has granted a nonexclusive license allowing Library and Archives Canada to reproduce, publish, archive, preserve, conserve, communicate to the public by telecommunication or on the Internet, loan, distribute and sell theses worldwide, for commercial or noncommercial purposes, in microform, paper, electronic and/or any other formats.

The author retains copyright ownership and moral rights in this thesis. Neither the thesis nor substantial extracts from it may be printed or otherwise reproduced without the author's permission.
AVIS:

L'auteur a accordé une licence non exclusive permettant à la Bibliothèque et Archives Canada de reproduire, publier, archiver, sauvegarder, conserver, transmettre au public par télécommunication ou par l'Internet, prêter, distribuer et vendre des thèses partout dans le monde, à des fins commerciales ou autres, sur support microforme, papier, électronique et/ou autres formats.

L'auteur conserve la propriété du droit d'auteur et des droits moraux qui protège cette thèse. $\mathrm{Ni}$ la thèse ni des extraits substantiels de celle-ci ne doivent être imprimés ou autrement reproduits sans son autorisation.
In compliance with the Canadian Privacy Act some supporting forms may have been removed from this thesis.

While these forms may be included in the document page count, their removal does not represent any loss of content from the thesis.
Conformément à la loi canadienne sur la protection de la vie privée, quelques formulaires secondaires ont été enlevés de cette thèse.

Bien que ces formulaires aient inclus dans la pagination, il n'y aura aucun contenu manquant.

\section{Canada}




\section{ABSTRACT}

This research uses data from 12 Open Educational Resource (OER) projects and 14 interviews and email responses from OER and Open Source Software (OSS) experts to identify: i) motives for establishing OER projects, ii) differences in governance between OER projects that use the co-production and the producer-consumer model for content development, iii) ways OER projects protect their content and, iv) uniqueness of OER relative to OSS.

The results of this research suggest that academic institutions and non profit organizations are establishing OER projects for social reasons more than for economic or technological reasons.

This study adds the governance dimension of intellectual property licenses to establish differences between OER projects that use the co-production and the producer-consumer model.

In addition, this study identifies five tactics used by OER projects to protect their content.

Finally, the results suggest six aspects that are unique to OER when compared to OSS. 


\section{ACKNOWLEDGEMENTS}

I would like to thank my supervisor, Prof. Tony Bailetti for his tireless guidance and support throughout the process of writing this thesis. Without his support, I would not have been able to come to Canada to pursue my dream of a master's degree. I will always be grateful for that.

In addition, I would like to thank Prof. Steven Muegge who always had the time to answer my questions when I asked him for advice.

I am most grateful for the financial support received by the Ontario's Talent First Network

To my love Renan, who gave me strength to complete my graduate program.

To my mother, Ivonne my father Régulo and my two sisters Jeny and Tati in Panama, who always supported me and encouraged me to pursue my dreams.

Last but not least, to my dear classmates and friends Kamal Hassin and Andrew Pullin. The endless hours we spent preparing assignments and presentations for our courses prepared me for the work of this thesis. 


\section{TABLE OF CONTENTS}

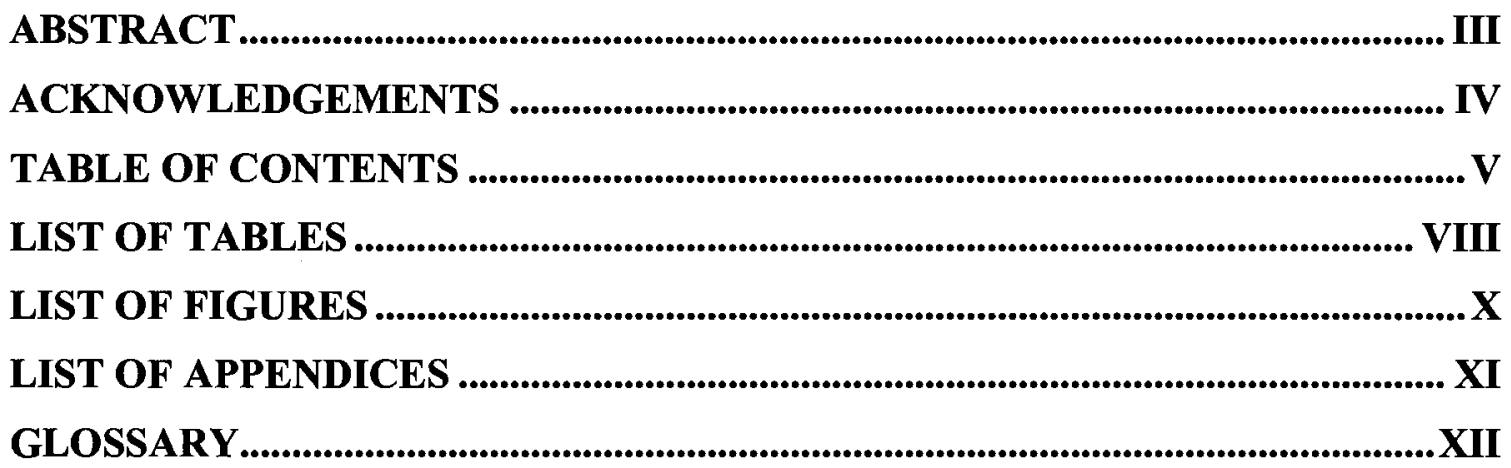

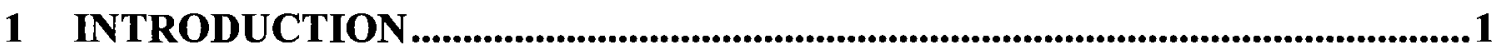

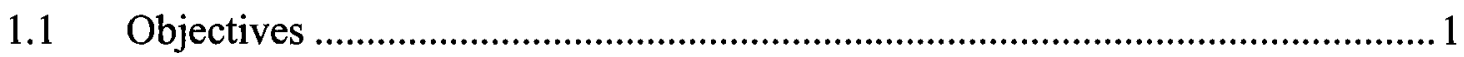

1.2 Rationale

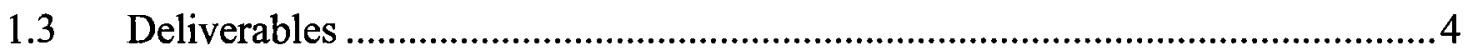

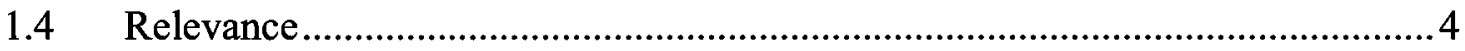

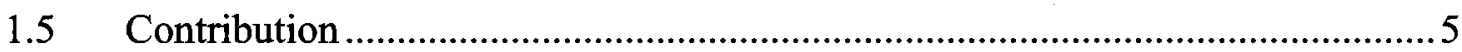

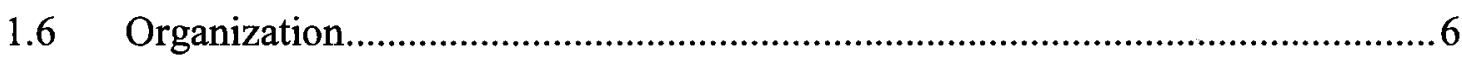

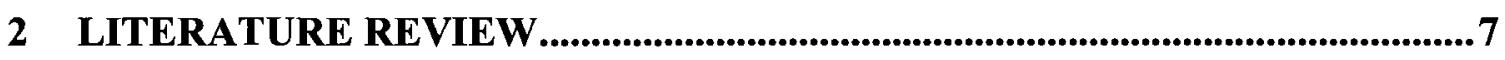

$2.1 \quad$ OER

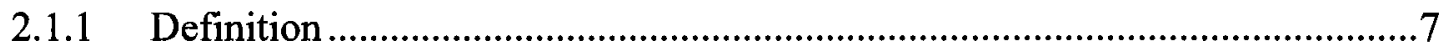

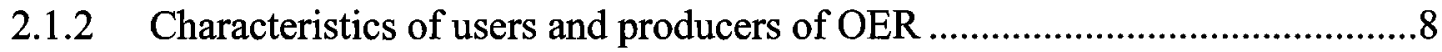

2.1.3 Characteristics of OER projects...........................................................

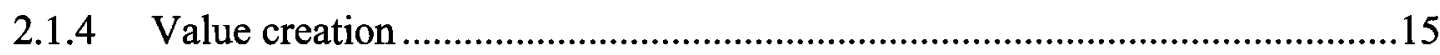

2.2 OSS

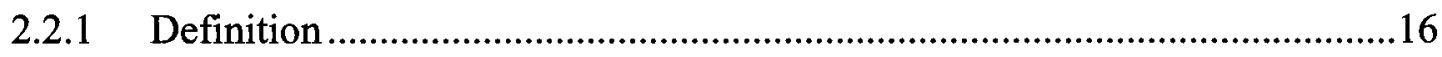

2.2.2 Characteristics of users and producers of OSS .......................................17

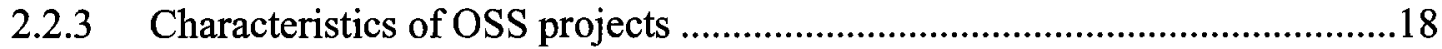

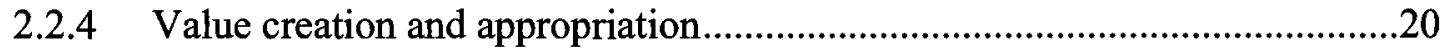

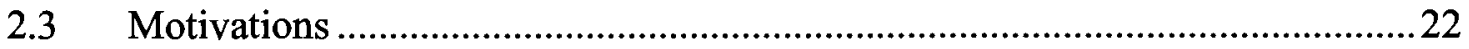

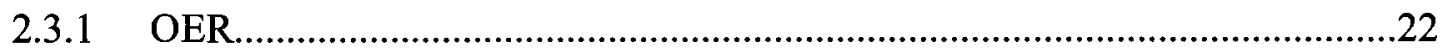

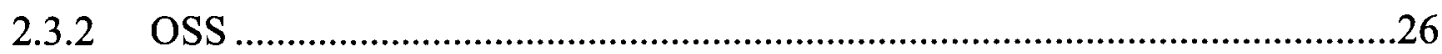

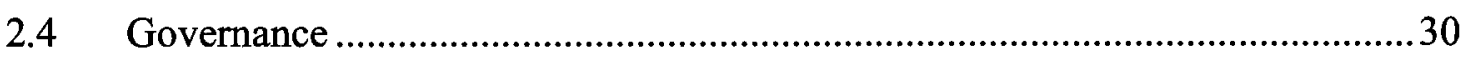

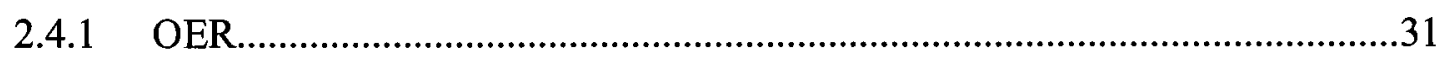




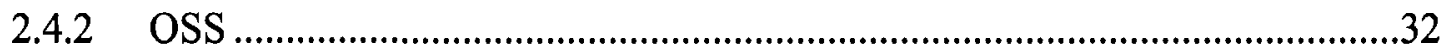

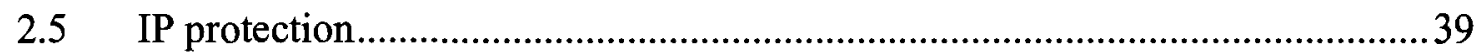

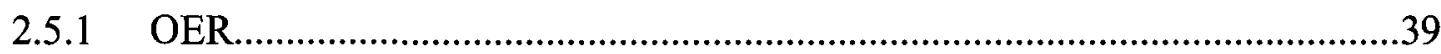

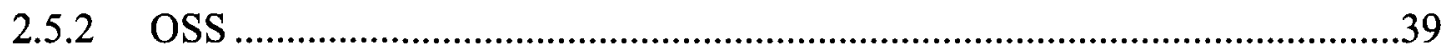

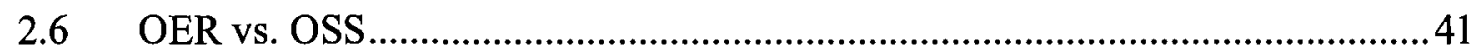

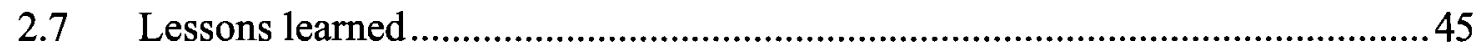

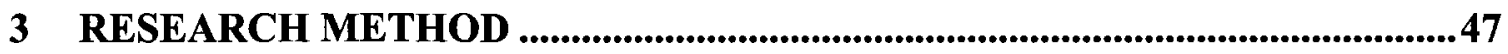

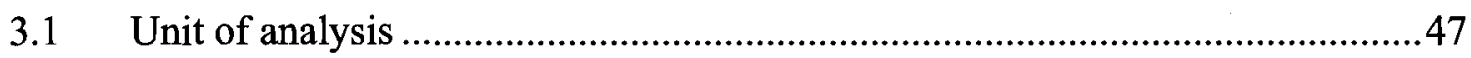

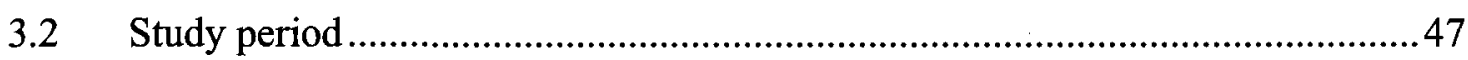

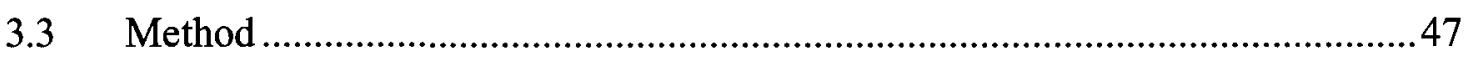

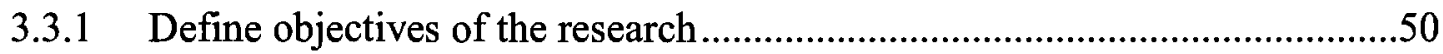

3.3.2 Extract governance dimensions from the OER and OSS literature ................50

3.3.3 Identify experts and prepare questionnaire to identify uniqueness of OER ..52

3.3.4 Identify sample of OER projects.................................................................54

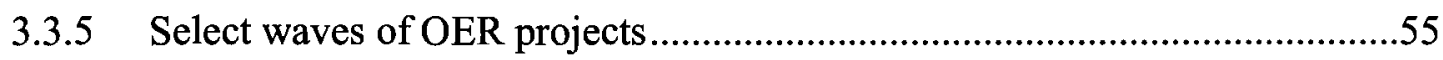

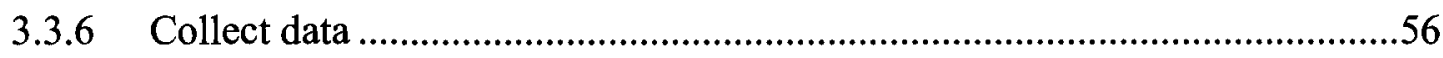

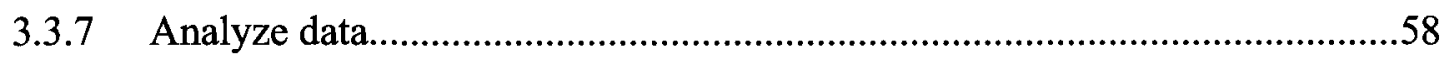

4 WRITE UPS OF OER PROJECTS IN THE SAMPLE .........................................61

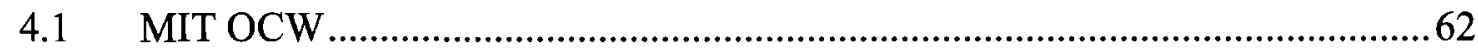

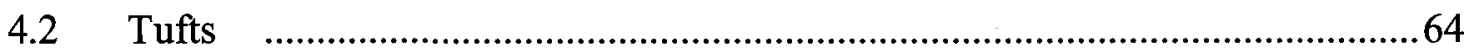

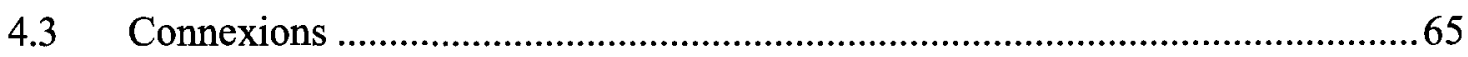

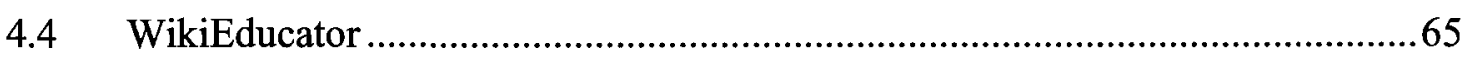

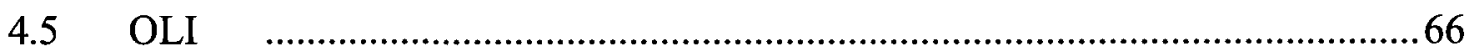

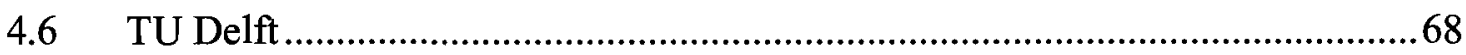

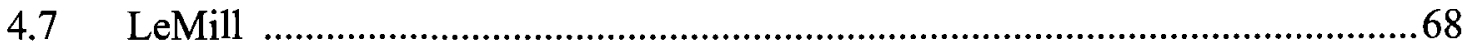

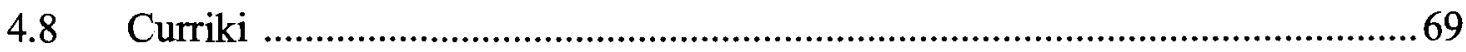

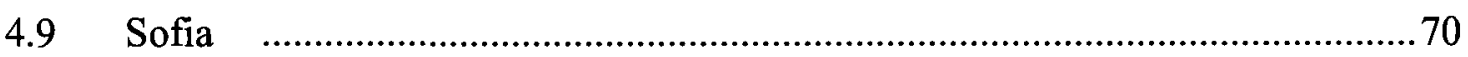

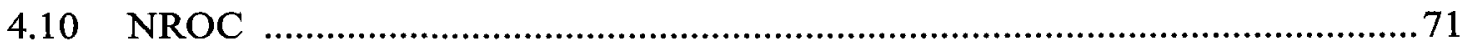

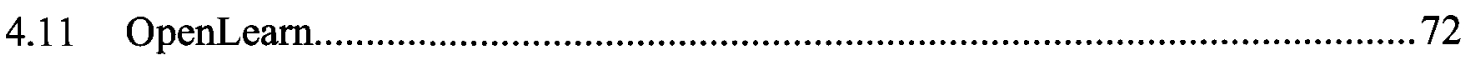

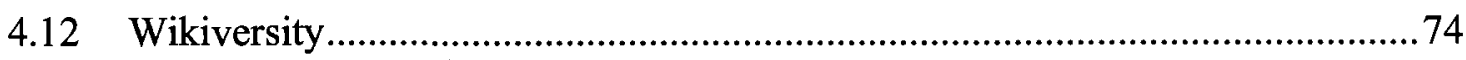

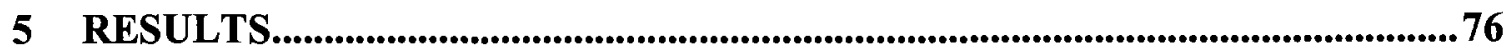

$5.1 \quad$ Motives for establishing OER projects ……………........................................76 
5.2 Differences between the governance used by OER projects that utilize the coproduction and the producer-consumer models for content development..........77

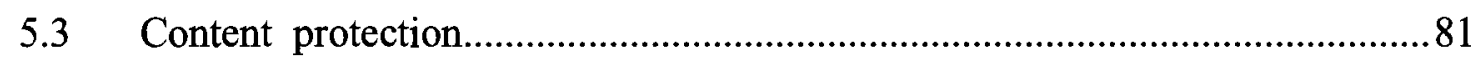

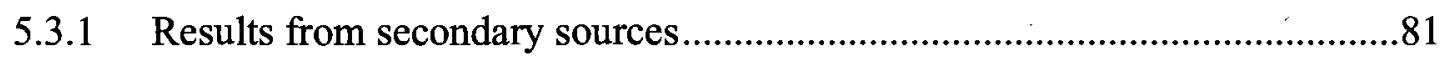

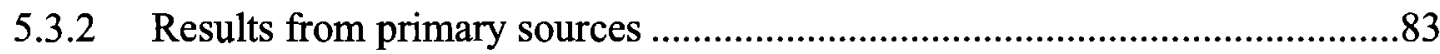

$5.4 \quad$ Uniqueness of OER

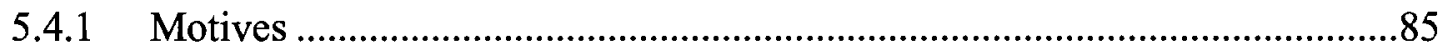

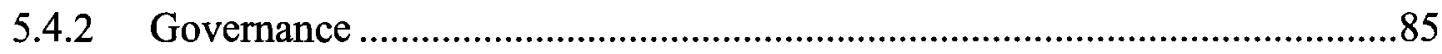

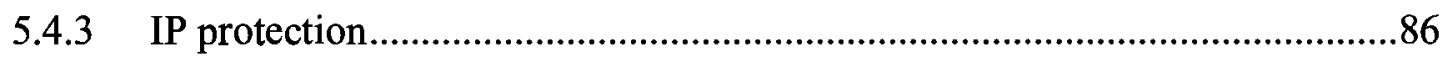

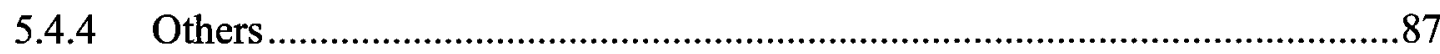

6 DISCUSSION OF RESULTS...............................................................................89

6.1 Motives for establishing OER projects .............................................................89

6.2 Differences in the governance used by OER projects that utilize the coproduction and the producer-consumer models for content development..........91

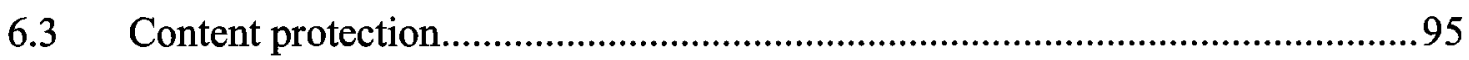

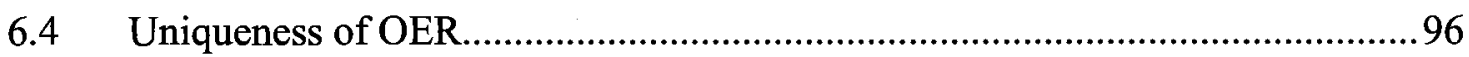

7 CONCLUSIONS, LIMITATIONS AND FUTURE RESEARCH........................98

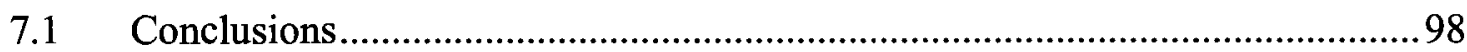

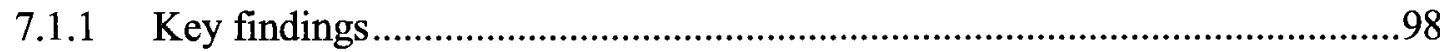

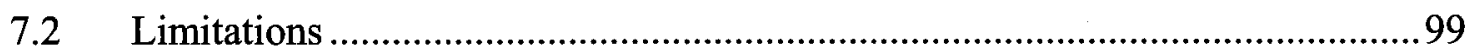

7.3 Opportunities for future research ..................................................................

8 REFERENCES ........................................................................................................................101 


\section{LIST OF TABLES}

Table 1 Characteristics of three models employed by higher education OER projects

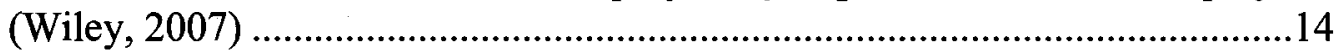

Table 2 Criteria software must comply to be considered OSS (OSI, 2008) ..................17

Table 3 Characteristics of the OSS development process (Feller \& Fitzgerald 2002)...20

Table 4 How OSS improves the competitive environment (Alam, 2006) ......................22

Table 5 Motivations of individuals to participate in OER projects................................23

Table 6 Motivations of institutions to participate in OER projects..................................24

Table 7 Motivations of individuals to contribute to OSS projects (Bonaccorsi \& Rossi,

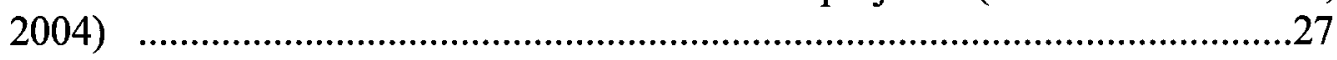

Table 8 Motivations of firms to participate in OSS (Bonaccorsi \& Rossi, 2004).........28

Table 9 Motivations of firms to establish and participate in OSS (Yang, 2006) ............30

Table 10 Characteristics of OER projects that use the co-production and productionconsumer model for content development (Keats, 2003) ...................................31

Table 11 Dimensions of governance in the OSS literature ..............................................33

Table 12 OSS governance categories (Markus, 2007)..................................................35

Table 13 Principles of the community managed governance model (O’Mahony, 2007) 36

Table 14 Tactics OSS projects use to protect their work (O'Mahony, 2003) ...................40

Table 15 Similarities between OER and OSS (Baldi et al., 2002) .................................42

Table 16 Differences between OER and OSS...............................................................44

Table 17 Research method ..........................................................................................

Table 18 Criteria for establishing differences in the governance of OER projects...........51

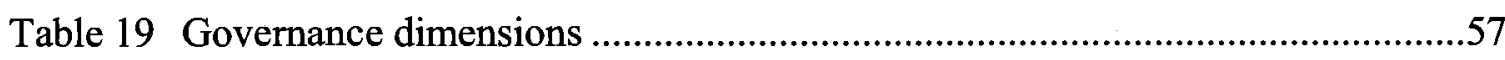

Table 20 OER projects included in the sample ......................................................62

Table 21 Motives for establishing OER projects ......................................................77

Table 22 Data on governance dimensions of OER projects that use the co-production

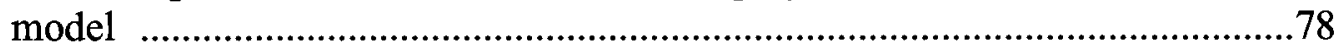

Table 23 Data on governance dimensions of OER projects that use the producer-

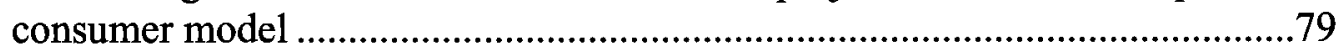

Table 24 Dimensions that can be used to establish differences between OER projects that use the co-production and the producer consumer models .........................79

Table 25 Tactics OER projects use to protect their content collected from secondary

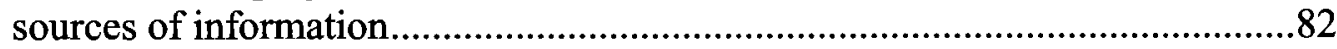


Table 26 Profile of the questionnaire respondents ..........................................................84

Table 27 Comparison between motives for establishing OER projects............................90

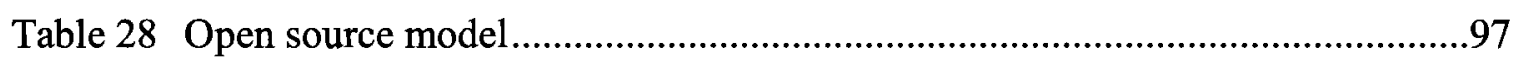




\section{LIST OF FIGURES}

Figure 1 Categories of OER providers (Joyce, 2006)..............................................

Figure 2 Examples of projects using the co-production and producer-consumer models (Organization for Economic Co-operation and Development, 2007) 


\section{LIST OF APPENDICES}

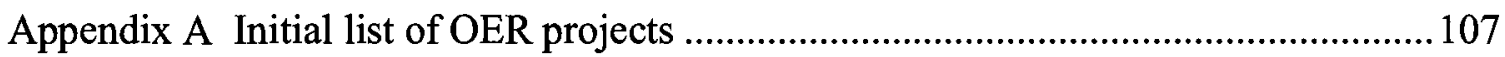

Appendix B Initial codes for categorizing motives for establishing OER projects........110

Appendix C Motives for establishing OER projects and their references.......................111

Appendix D Final codes and phrases for categorizing motives for establishing OER

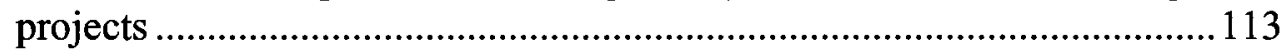

Appendix E Information used to collect the data on five governance dimensions ....... 114

Appendix F Codes for categorization of tactics OER projects use to protect their content

Appendix G Tactics used by OER projects to protect their content and their references 
GLOSSARY

CC, BY-NC-SA Creative Commons, Attribution-Noncommercial-Share Alike

COL

Commonwealth of Learning

FSF

Free Software Foundation

GFDL GNU Free documentation license

GPL

General Public License

IP

Intellectual Property

MIT

Massachusetts Institute of Technology

NGO

Non-governmental organization

NRCO

National Repository of Online Courses

OCW

OpenCourseWare

OECD

Organization for Economic Co-operation and Development

OER

Open Educational Resources

OLI

Open Learning Initiative

OSI

Open Source Initiative

OSS

Open Source Software 
OU

RPV

UNESCO
Open University

Resources, Processes and Values

United Nations Educational, Scientific and Cultural Organization 


\section{INTRODUCTION}

Open Educational Resources (OER) are: "digitized materials offered freely and openly for educators, students and self-learners, for use and reuse in researching, teaching and learning" (Organization for Economic Co-operation and Development, 2007). OER allow free usage, distribution and modification of content without the traditional restrictions imposed by copyright (Organization for Economic Co-operation and Development, 2007).

The OER movement has gained momentum in recent years. Several academic institutions, non profit organizations and world bodies have started OER projects with academic and altruistic objectives. A representative OER project covered by the Creative Commons license ${ }^{1}$ is the MIT OpenCourseWare (OCW) led by the Massachusetts Institute of Technology (MIT) ${ }^{2}$. MIT makes available its undergraduate and graduatelevel courses online for free to anyone, anywhere. This project has increased the interest of different organizations such as UNESCO and the William and Flora Hewlett Foundation to promote OER projects, especially because of the potential of OER to promote access to education in developing countries.

\subsection{Objectives}

The objective of this research is to answer four research questions:

\footnotetext{
${ }^{1} \mathrm{http}: / /$ creativecommons.org

${ }^{2}$ http://ocw.mit.edu
} 
1. What are the motives of academic and non profit institutions for establishing OER projects?

2. What are the differences between the governance used by OER projects that utilize the co-production and the producer-consumer model for content development?

3. How do OER projects protect their content?

4. What is unique about OER relative to open source software (OSS) in terms of: i) motives for establishing the projects, ii) governance of the project and content production and, iii) intellectual property (IP) protection?

For the purpose of this research, motives refer to the reasons academic and non profit institutions have to establish OER projects. The motives analyzed in this study are those from OER project directors and managers of the institutions that host these projects as stated in their projects' websites.

Governance is defined as the means of achieving the direction, control and coordination of individuals and organizations to achieve the goals of a project (Markus, 2007; O'Mahony, 2007). Governance is defined in terms of five dimensions drawn from the OSS and OER literature (Keats, 2003; O'Mahony, 2007; Markus, 2007). These dimensions correspond to the governance of the project and content production. From the OER literature (Keats, 2003; Organization for Economic Co-operation and Development, 2007) three dimensions were selected: i) organizational structure, ii) participation of volunteer contributors and, iii) number of partnerships. From the OSS literature (O'Mahony, 2007; Markus, 2007), two dimensions were selected: i) intellectual property licenses and, ii) core mission. 
IP protection refers to the tactics used by OER projects to protect the content they make freely available.

\subsection{Rationale}

Resources, processes and values define an organization's strengths, weaknesses and blind spots (Christensen, Anthony \& Roth, 2004). Resources are things or assets that organizations can buy or sell, build or destroy. Processes are the established patterns of work by which companies transform inputs into outputs of greater worth. Finally, values determine the criteria by which organizations allocate their resources (Christensen et al., 2004).

Two aspects of processes (governance and IP protection) and one from values (motives) were selected for this research. A review of the OSS literature suggested these three aspects were worth studying (Bonaccorsi \& Rossi, 2003; Markus, 2007; O’Mahony, 2003).

The OSS literature highlights three areas of study: motivations of contributors, innovation process, and competitive dynamics (von Krogh \& von Hippel, 2006). The area of motives for establishing OER projects was chosen from the area of motivations of contributors. The areas of governance and IP protection were chosen from the innovation process of OSS (von Krogh \& von Hippel, 2006).

Firms are not investing in OER projects as much as they are in OSS projects (Mora, 2007). Therefore, the area of competitive dynamics of OSS (von Krogh \& von Hippel, 2006), which focuses on how firms compete with OSS, was not chosen to study OER. 


\subsection{Deliverables}

This research delivers:

1. Motives for establishing OER projects as stated by the project managers and managers of the institutions that host the projects

2. Differences between the governance used by OER projects that utilize the coproduction and the producer-consumer model for content development

3. Ways OER projects protect their content

4. Uniqueness of OER relative to OSS in terms of: i) motivations for establishing the projects, ii) governance of the project and content production and, iii) IP protection

5. Write ups on 12 OER projects

\subsection{Relevance}

This research is relevant to OER project directors in academic institutions and non profit organizations, directors of world organizations committed to disseminating education in developing countries and researchers and students interested in OER and OSS.

First, when establishing OER projects in academic institutions and non profit organizations, project directors can use this research to make informed decisions about how to protect their content and the governance for OER projects.

Second, directors of world organizations interested in OER can assess the characteristics and variety of current OER projects by examining the write ups delivered in this thesis. 
Third, students and researchers interested in the open source model can obtain a better understanding of the phenomenon by examining what is unique about OER relative to OSS.

\subsection{Contribution}

This research offers at least three contributions. First, this research contributes to our understanding of the open source model by identifying what is unique about OER when compared to OSS in terms of: i) motivations for establishing the projects, ii) governance of the project and content production and, iii) IP protection. The literature identifies high level differences and commonalities between OER and OSS. However, these general observations are not anchored on specific OER projects.

The OSS literature was used as a benchmark for this research for two reasons. First, OER and OSS share the value of openness and both are motivated by the expected social benefits and ethical considerations related to freedom to use, contribute and share resources (Organization for Economic Co-operation and Development, 2007; Baldi, Heier \& Stanzick, 2002; Tuomi, 2006).

The second reason that the OSS literature was used as a benchmark is that it emphasizes similarities and differences between OER and OSS. The Report on the Discussion on OSS for OER (2006) reviews OSS practices and produces lessons learned that can be applied to OER. Baldi, Heier and Stanzick (2002) identify differences in the processes used to develop OER and OSS. Mora (2007) explains differences between OER and OSS in terms of business models, quality assurance and reuse. 
The second contribution of this research is that it adds to the literature on digital intellectual property management by identifying and categorizing the ways OER projects protect their content. Previous research has analyzed the ways OSS maintains and exercise rights over their work (O'Mahony, 2003). However, we do not know how OER projects protect their content.

The third contribution of this research is the insights gained from comparing the governance of OER projects that utilize the co-production and the producer-consumer model for content development. The Organization for Economic Cooperation and Development (2007) distinguishes two approaches for content development in OER projects: co-production and producer-consumer model. Keats (2003) and the Organization for Economic Cooperation and Development (2007) identify three distinguishing dimensions for these two approaches: i) organizational structure, ii) participation of volunteer contributors in the development of content and, iii) partnerships. However, no case-based evidence is provided to support these differences.

\subsection{Organization}

This thesis is organized into seven chapters. Chapter 1 is the introduction. Chapter 2 provides the literature review that supports this research. Chapter 3 presents the research method. Chapter 4 presents the write ups of the OER projects in the sample. Chapter 5 provides the research results. Chapter 6 discusses the results. Finally, chapter 7 provides the conclusions, limitations and opportunities for future research. 


\section{LITERATURE REVIEW}

This chapter is organized into seven sections. Section 2.1 reviews the OER literature on the characteristics of users and producers of OER, characteristics of the projects and how value is created. Section 2.2 reviews the OSS literature on the characteristics of users and producers of OSS, characteristics of the projects and how value is created and appropriated. Section 2.3 presents the literature on motivations to participate in OER and OSS projects. Section 2.4 presents the literature on governance of OER and OSS. Section 2.5 presents the literature on intellectual property protection of OER and OSS. Section 2.6 reviews the literature that compares OER and OSS. Finally, section 2.7 provides the lessons learned from the literature review.

\subsection{OER}

\subsubsection{Definition}

Although there is not an "authoritatively accredited definition" of OER, (Geser, 2007) there are accepted interpretations of OER. The Organization for Economic Co-operation and Development-OECD (2007) and Hylén (2006) provide a reference point for the ongoing discussion towards a notion of OER (Geser, 2007).

OER refer to: digitized materials offered freely and openly for educators, students and self-learners, for use and reuse in researching, teaching and learning. OER allow free usage, distribution and modification with out the traditional restrictions imposed by copyright (Organization for Economic Co-operation and Development, 2007).

OER can include open content, but is not limited to it (Hylén, 2006). OER can include: 
- Learning content: full courses, courseware, content modules, learning objects, collections, and journals

- Tools: software to support the development, use, re-use and delivery of learning content including searching and organization of content, content and learning management systems, content development tools, and on-line learning communities

- Implementation resources: intellectual property licenses to promote open publishing of materials, design principles of best practice, and localization of content

Open content refers to text, sound and images that the general public can freely use, distribute and modify without the traditional restrictions imposed by copyright (Liang, 2007). These actions are sanctioned by an open content license that provides the greatest freedom: the right to modify and distribute (Liang, 2007). Open content can also be in the public domain or under an open license like one of the Creative Commons licenses. The largest open content project is Wikipedia. The phrase open content was coined to be similar to open source (Mora, 2007).

\subsubsection{Characteristics of users and producers of OER}

The results of a web-based survey (Organization for Economic Co-operation and Development, 2007) indicate that the majority of OER producers are located in Western countries. The institutions producing OER benefit from international or national reputations. They are not low-status institutions. Institutional based initiatives use their own staff to produce OER. In terms of OER users, Carson (2006) reports that visitors of the MIT OCW most frequently identify themselves as self learners. Students are in second place and educators in third place. 


\subsubsection{Characteristics of OER projects}

Figure 1 provides the categorization of OER providers prepared by Joyce (2006). OER projects can be classified according to: i) whether the provider is an institution or a community and, ii) whether their scale of operation is small or large. Institutional and community OER providers differ in their approach to develop OER.

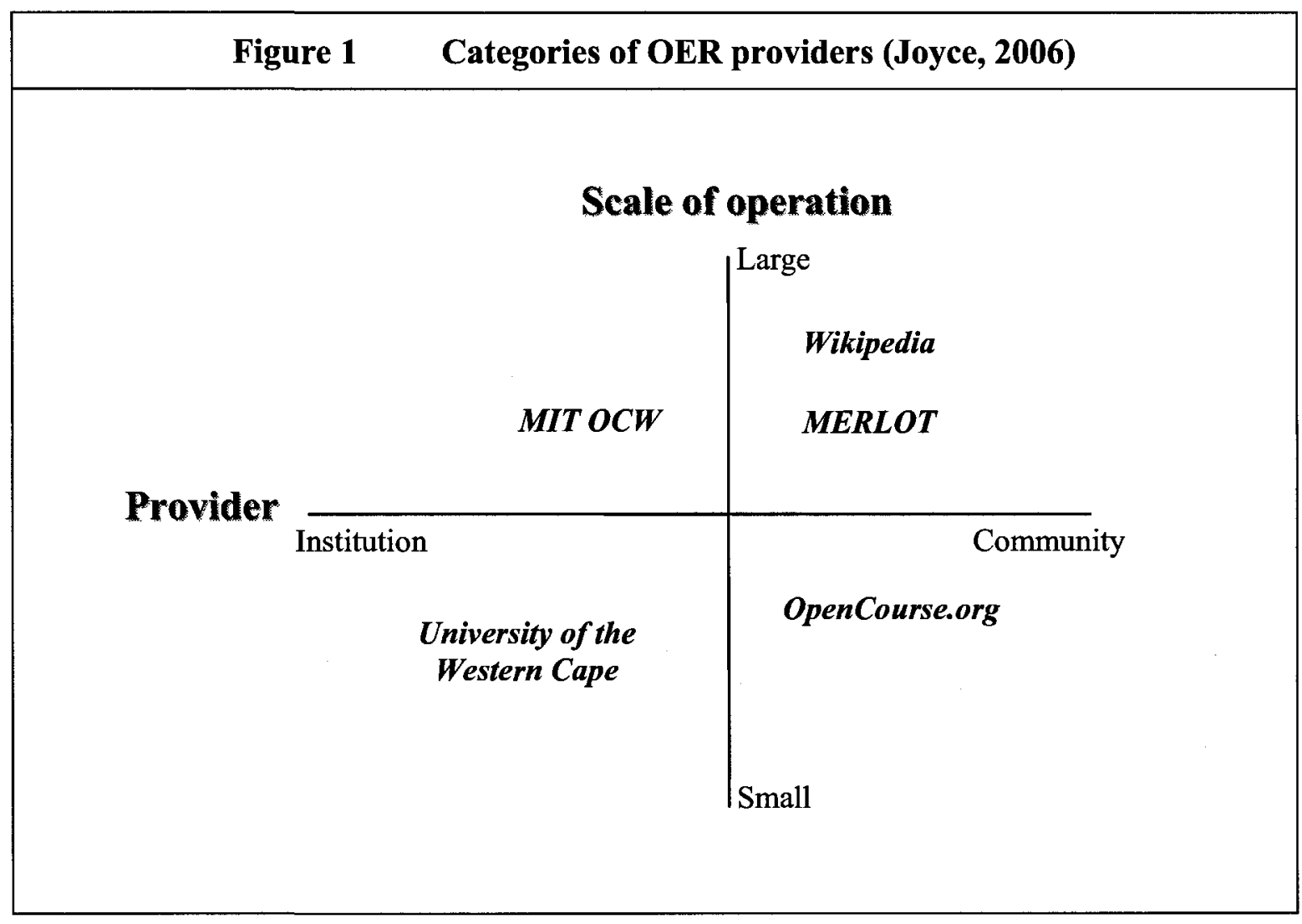

The MIT OCW is an example of a large scale institutional based OER project. The African Virtual Open Initiatives and Resources-AVOIR ${ }^{3}$ project at the University of the Western Cape is classified as a small institutional project. The project is a collaborative effort among several African higher education institutions to support capacity building

\footnotetext{
${ }^{3}$ http://avoir.uwc.ac.za/avoir
} 
(software design, development, deployment and support) in Free and Open Source software engineering. Wikipedia ${ }^{4}$ and Merlot $^{5}$ are examples of large scale community based OER projects. Finally, opencourse. $\mathrm{org}^{6}$ is a small scale institutional OER project that hosts virtual communities developing, evaluating and using open, non-proprietary learning objects.

\section{$\underline{\text { Institutional based OER projects }}$}

While there are examples of collaboration among academics in developing joint content, the largest proportion of existing OER materials in institutional based projects are originated by an individual faculty member. Lecturers typically need support to address licensing issues, and require help designing their materials and turning them into webbased resources (UNESCO-OER, 2008).

The creators of the materials in the MIT OCW are the teachers themselves. They are fully paid academics, who must produce materials for one of their core professional roles: teaching college and graduate level courses ("OpenCourseWare how to" website, 2008). The MIT OCW staff is responsible for the actual publishing process (Stacey, 2007).

OCW publications are static snapshots of course materials as used in a particular term by an instructor (Stacey, 2007).

\footnotetext{
${ }^{4}$ www.wikipedia.org

${ }^{5}$ www.merlot.org

${ }^{6}$ www.opencourse.org
} 


\section{Community based OER projects}

The extant literature on community based OER projects focuses on the characteristics of individual projects such as Wikipedia and Connexions?

Wikipedia is a web-based encyclopedia that anyone with Internet access can edit. Wikipedia is open to a large contributor base, drawing a large number of editors from diverse backgrounds (Wikipedia, 2008).

Wikipedia is written collaboratively by volunteers from around the world. Its articles can be edited by simply clicking the "edit this page" links. Anyone is welcome to add information, cross-references or citations, as long as they do so within Wikipedia's editing policies (Ogbuji, 2007).

Connexions, a community based OER project of Rice University, is a repository of scholarly materials and open source software tool kit to help authors publish and collaborate, instructors rapidly build and share customer courses and learner explore the links among concepts, courses and disciplines (Dholakia, King \& Baraniuk, 2006).

Connexions uses modules of information, which are documents intended to communicate one particular concept, one procedure or one set of questions about something (Dholakia et al., 2006). Authors can work collaboratively or alone using special authoring tools to create and refine these small, self-contained modules of information. These knowledge

\footnotetext{
${ }^{7}$ http://cnx.org
} 
building blocks are maintained in a repository, or Content Commons, to be used, re-used, updated, and adapted (Henry, Baraniuk \& Kelty, 2003).

Connexions opens up the editorial process to an unlimited number of third-party reviewers and editorial bodies for post-review of the modules. Users have the ability to preferentially locate and view knowledge modules and courses rated high-quality by choosing from a range of different lenses provided by these third parties (Henry et al., 2003).

Figure 2 provides a third dimension to classify institution and community based OER projects (Organization for Economic Co-operation and Development, 2007) according to the level of integration of users in the production process (co-production or producerconsumer model).

The producer-consumer model is more likely to be managed centrally and involve professional staff. The model offers more control over quality and content, but requires higher levels of funding (Organization for Economic Co-operation and Development, 2007). The co-production model is more likely to depend on decentralised management, and there is little or no control over quality and content, but this approach requires much less funding (Organization for Economic Co-operation and Development, 2007). 
Figure 2 Examples of projects using the co-production and producer-consumer models (Organization for Economic Co-operation and Development, 2007)

Co-production

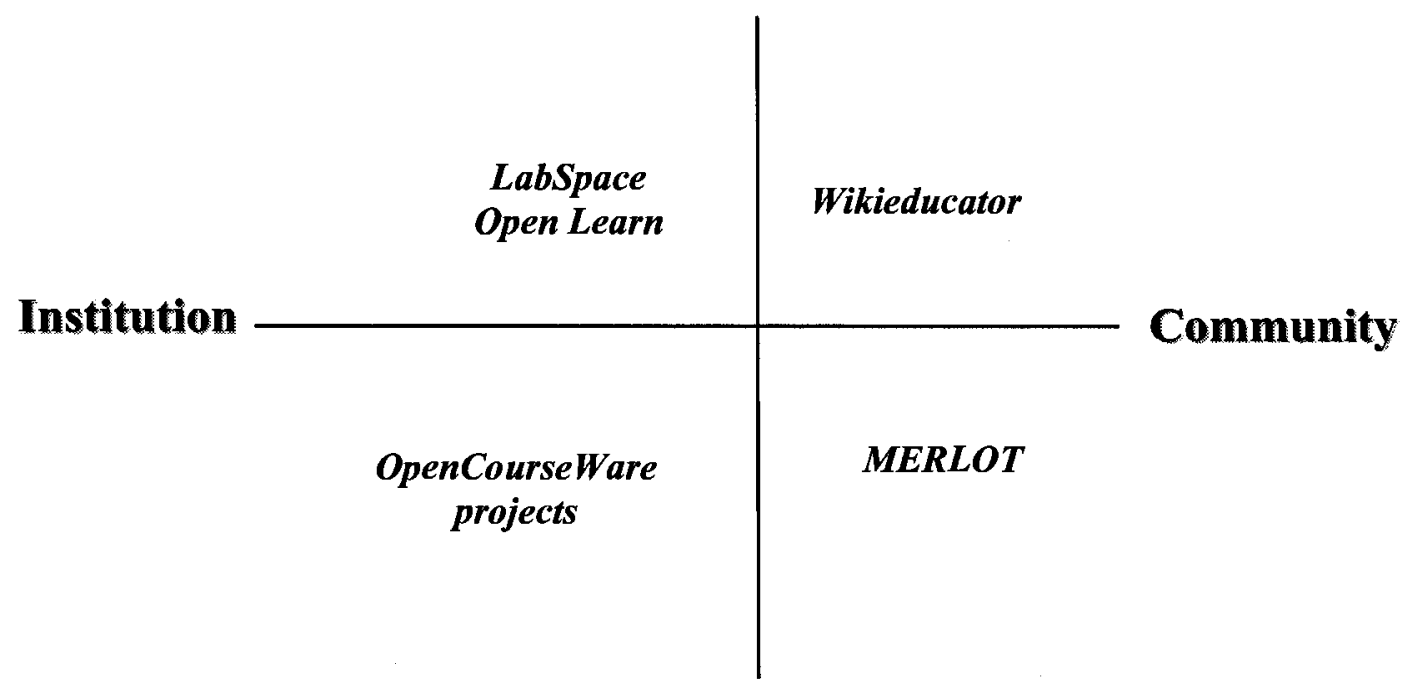

Producer-consumer

Figure 2 shows examples of institution based initiatives using the co-production model and the producer-consumer model, as well as community based projects using the two different approaches. LabSpace from the OER project OpenLearn is an example of an institution based project established for co-production of its resources. OpenLearn also host a project called LearningSpace that uses courses taught at the UK Open University produced by their teaching staff (Organization for Economic Co-operation and Development, 2007). Wikieducator is a community intended for the collaborative development of OER that welcomes scholars, teachers and trainers who are interested in the collaborative authoring and development of OER (Wikieducator website, 2008). 
Merlot is a community based OER project that is less oriented towards collaborative production of content. It is more a place to exchange and share with peers than to coproduce (Organization for Economic Co-operation and Development, 2007).

OpenCourseWare projects develop courses taught at universities and the content is backed by the host institution. The courses are produced by the teaching staff and consumed by others (Organization for Economic Co-operation and Development, 2007).

OER projects in higher education are highly diverse in terms of their goals, organizational configurations and the cost per course produced (Wiley, 2007). The degree of control over the courses is also highly diverse among OER projects (Wiley, 2007; Keats, 2003). Table 1 highlights the differences between OER projects in higher education in terms of course production, control over courses produced, cost per course produced and organization size (Wiley, 2007).

Table 1 Characteristics of three models employed by higher education OER projects (Wiley, 2007)

\begin{tabular}{|l|l|l|l|}
\hline \multirow{2}{*}{ Characteristics } & \multicolumn{3}{|c|}{ OER project } \\
\cline { 2 - 4 } & \multicolumn{1}{|c|}{ MIT OCW } & $\begin{array}{c}\text { Utah State } \\
\text { University (USU) } \\
\text { OCW }\end{array}$ & \multicolumn{1}{|c|}{ Connexions } \\
\hline Course production & $\begin{array}{l}\text { All courses offered } \\
\text { by MIT }\end{array}$ & $\begin{array}{l}\text { Many courses } \\
\text { offered by USU }\end{array}$ & $\begin{array}{l}\text { Many courses } \\
\text { offered anywhere }\end{array}$ \\
\hline $\begin{array}{l}\text { Control over } \\
\text { courses produced }\end{array}$ & $\begin{array}{l}\text { High degree of } \\
\text { control }\end{array}$ & $\begin{array}{l}\text { Small degree of } \\
\text { control }\end{array}$ & $\begin{array}{l}\text { Practically no } \\
\text { control }\end{array}$ \\
\hline $\begin{array}{l}\text { Cost per course } \\
\text { produced }\end{array}$ & USD 10,000 & USD 5,000 & USD 0 \\
\hline Organization size & Large & Medium & Small \\
\hline
\end{tabular}

OER allow teachers to provide resources with their own personal assessments, lessons learned and suggestions for improvement. In addition, it promotes user centred 
approaches in education and lifelong learning. Users are able to develop their own online portfolios, and share study results and experiences with peers (Geser, 2007).

\subsubsection{Value creation}

Dholakia et al. (2006) identify four key components that provide significant value to the users of the OER project Connexions. The first value component is the differentiated and consistent brand image that has been created around Connexions. Users associate the Connexions brand with the values the brand stands for, such as making knowledge free and open, promote education in the developing world, provide an open access platform to support collaboration and improve the ways educational content is created and used.

The second value component offered by Connexions is high quality content published on demand. The content available within Connexions is modular and can be updated frequently and customized to the needs of the instructor or students. On demand books printed with Connexions content can be organized into self contained modules of information.

The third value component refers to an engaged and involved user community. Technological features of the Connexions site help to foster collaboration between users. Connexions also work with interested groups to help them build a community of authors, instructors and students and develop a critical mass of materials.

The fourth value component is site usability. Connexions strive to be easy to use for authors and users. In addition, Connexions has a search system to allow users to easily find the content modules within its repository. 


\subsection{OSS}

\subsubsection{Definition}

The definition of the term open source is often related to a set of development methods for software that harnesses the power of distributed peer review and transparency of the development process (Open Source Initiative, 2008).

Bailetti (2007) adds to this definition of open source by stating that although the term open source is most commonly used to refer to software "under the leadership, structure and governance of open source projects, individuals, companies, and organizations also produce integrated circuits, printed circuit boards, standards, platforms, content, scientific knowledge, and workflows".

Bailetti and Hoddinott (2007) argue that there is ambiguity in the usage of the word "source" in the term open source software. Source can refer to the computer code or the process used to produce the code. For example, in an open source project the code can be open but the process used to produce it can be controlled by a single entity or company. There are four possible cases if the two definitions are combined: open process and open computer code, closed process and open computer code, open process and closed computer code and closed process and closed computer code which refers to the case of proprietary software.

According to the Open Source Initiative (OSI), OSS is not limited to access to the source code. The distribution terms must satisfy ten principles to be considered open source, the majority of them being related to the distribution license of the software. Table 2 presents 
the ten criteria from the OSI organized into two groups: i) criteria related to the distribution license and, ii) general criteria.

Table 2 Criteria software must comply to be considered OSS (OSI, 2008)

\section{License related}

1. Free redistribution by any party to sell or give away the software

2. License that allows modification and derived works

3. Integrity of the author's source code in derived works through different names or version number from the original software

4. License applicable to all to whom the program is distributed

5. License must no be specific to a product

6. License must not restrict other software

7. License must be technology-neutral

\section{General}

8. Program must include source code

9. No discrimination against persons or groups

10. No discrimination against fields or endeavours

\subsubsection{Characteristics of users and producers of OSS}

In terms of the producers of OSS, Feller and Fitzgerald (2002) argue that "OSS developers tend to be professionals and specialists, both significant characteristics".

These characteristics of OSS developers help to explain how the largely uncoordinated efforts of individual developers can lead to software that is highly robust, since professionals bring industry best practices to solve OSS problems. Likewise, specialists are likely to show great passion for the subject matter, therefore they are eager to contribute to the production of efficient applications and components (Feller \& Fitzgerald, 2002). 
Nichols and Twidale (2003) comment about OSS users: "Traditionally the users of OSS have been experts, early adopters, and nearly synonymous with the development pool". As OSS enters the commercial mainstream it is widening to include many nondevelopers. Their study of OSS indicates there is a problem of poor usability for nonexpert users. They present a set of features of the OSS development process that appear to contribute to the problem. However, they state that some of these features are also found in proprietary software, these problems are not exclusive to OSS.

\subsubsection{Characteristics of OSS projects}

Bonaccorsi and Rossi (2003) identify the characteristics of the life cycle of OSS projects. They describe a successful OS project as one that typically starts when an individual or organization faces a problem that needs a particular software that does not exist in the market. Subsequently, this individual or organization will form a group to solve the problem. As the project advances, the group looks for feedback through mailing lists and other related media. At this point, new contributors are added while others can leave the project. The increase in participation allows launching frequent releases and gaining feedback to improve the code. Coordination among developers follows a bottom up approach that relies on communication protocols and a shared notion of validity, according to which "the solutions that not only exhibit the best performance but also look simple, clear and logic are selected, thus guarantying non-chaotic future expansion of the work" (Bonaccorsi \& Rossi, 2003). These elements are enhanced by the characteristics of the software, particularly its modularity. Modularity simplifies the division of labour among programmers (Bonaccorsi \& Rossi, 2003). 
OSS projects are managed by a large number of volunteers, working freely on the tasks they choose to undertake. OSS projects also rarely rely on project plans or schedules. Moreover, OSS developers work in arbitrary locations and collaborate almost exclusively over the Internet, using simple tools such as email and software code tracking databases (Sack, Detienne, Ducheneaut, Burkhardt, Mahendran \& Barcellini, 2006).

Kogut and Metiu (2001) describe two sources of efficiency gain in the OSS development process when compared to closed source software development: i) advantage of users being contributors and, ii) the concurrent debugging and design that occurs in a decentralized environment.

Feller and Fitzgerald (2000) define OSS as a massive parallel development. OSS development does not provide formally documented norms or customs. However, there are customs learned by experience. Face to face meetings are not the norm for OSS developers. The OSS development process relies heavily on the Internet for the submission and testing of code patches (Feller \& Fitzgerald, 2000).

The OSS development process is loosely-centralized, cooperative and obtains free contributions from individual developers (Feller \& Fitzgerald, 2000).

Table 3 provides the characteristics of the development process common to most OSS projects that were identified by Feller and Fitzgerald (2002). 


\section{Table 3 Characteristics of the OSS development process (Feller \& Fitzgerald} 2002)

- OSS development takes place among distributed teams

- Participants come from many different parts of the world

- Participants can communicate and collaborate primarily through the Internet.

- Parallel process rather than linear

- Involves large communities of globally distributed developers

- Utilizes truly independent peer review

- Provides prompt feedback to user and developer contributions

- Includes the participation of highly talented, highly motivated developers

- Includes increased levels of user involvement

- Makes use of extremely rapid release schedules

\subsubsection{Value creation and appropriation}

Baldwin and Clark (2006) proved that the modularity and option value inherent in software architecture can change developers' incentives in ways that mitigate free riding in a collective process. Modularity is defined as the property of the software to be divided into modules which can be concurrently designed and implemented as long as they obey the design rules. Option value is defined as the right but not the obligation to choose a course of action and obtain an associated payoff. In the case of software, a new design creates the ability, but not the necessity, to do something in a new way. The design will be adopted only if it is better that the old (Baldwin \& Clark, 2006).

Comino, Manenti and Parisi (2007) concluded that free riding does not undermine cooperation in large groups of developers. Free riding does not pose severe problems for OSS innovation. Von Hippel and von Krogh (2003) observe the same characteristic in OSS projects, when the innovation process is analyzed as an example of a private- 
collective model of innovation. OSS shows characteristics of both the collective action model and private investment models of innovation (von Hippel \& von Krogh, 2003).

OSS is considered a public good (Lerner \& Tirole, 2002; von Krogh, Spaeth \& Lakhani, 2003; von Krogh \& von Hippel, 2006), and its use is nonrival because the use of the code by one developer does not prevent its use by another (Baldwin \& Clark, 2006). OSS involves the use of a copyright-based license to prevent private intellectual property claims from both software innovators and software adopters, while at the same time preserving an asset that anyone can access (von Krogh \& von Hippel, 2006).

Alam (2006) analyzed twelve companies that established OSS projects to examine how OSS improved the company's competitive environment. Four dimensions were analyzed: i) factor conditions, ii) demand conditions, iii) context for strategy and rivalry and, iv) related and supporting industries. These four dimensions are the company's competitive environment that interact together to create forces that provide pressures, incentives and capabilities for firms to innovate (Alam, 2006). Table 4 summarizes the results reported by Alam (2006). 
Table 4 How OSS improves the competitive environment (Alam, 2006)

\section{Factor conditions}

- OSS developers do work that enhances the value of the company's products

- Develop stacks of components that can be embedded into customer's products

- Obtain products that complements company's products

- Hire talent for the company

- Use OSS to experiment with new technology

\section{Demand conditions}

- Experiment with new product concepts

- Lower cost of acquiring customers

- Create demand for new markets

\section{Context for strategy and rivalry}

- Set and maintain dominant standard

- Create dominant position in delivery of services around the OSS project

- Acquire external technology without the need for contractual agreements

- Low barrier to imitation makes companies develop new ways to profit

\section{Related and supporting industries}

- Promote knowledge sharing and co create value

- Influence technical efforts of suppliers and partners

\subsection{Motivations}

\subsubsection{OER}

\section{Motivations of individuals}

Table 5 provides a summary of the motivations of individuals to participate in OER projects identified in the literature review. 


\begin{tabular}{|c|c|}
\hline Motivations of individuals to participat & in OER projects \\
\hline Motivations & Reference \\
\hline $\begin{array}{l}\text { - Gaining access to good quality, flexible materials and } \\
\text { enabling exchange with colleagues } \\
\text { - Keeping students and alumni up to date }\end{array}$ & Joyce, 2006 \\
\hline - Easier content dissemination & Parker, 2007 \\
\hline $\begin{array}{l}\text { - Reach a greater audience for opportunities to collaborate } \\
\text { in improving the content }\end{array}$ & $\begin{array}{l}\text { Joyce, 2007; Parker, } \\
2007\end{array}$ \\
\hline - Showcasing and promotion of work, greater recognition & $\begin{array}{l}\text { Downes, 2006; Joyce, } \\
\text { 2006; Parker, } 2006\end{array}$ \\
\hline - Ethical obligation to share their work & $\begin{array}{l}\text { Downes, 2006; Joyce, } \\
2006\end{array}$ \\
\hline
\end{tabular}

Individuals produce OER to gain access to the best possible materials and have materials reusable for different purposes and academic contexts. Other motivations include: widening access, keep students up to date, opportunity to collaborate with a wider group in the improvement of the content, showcase, and self promotion. Academics are motivated because they feel: i) ethical obligations to share their work and knowledge as widely as possible and the opportunity to reach new learners and, ii) want to help graduates and other alumni to stay up to date in their fields (Joyce, 2006).

In a qualitative case study, Parker (2007) identified what benefits the instructors attribute to participating in and contributing to the Utah State and the MIT OCW. The results suggest that the main benefits the instructors receive are greater recognition, compensation from private companies who sponsor the courses for public use, the possibility to reach a greater audience and thus get feedback on their materials used in 
new contexts, easier content dissemination among students and colleagues, and connections that have resulted in better publishing opportunities (Parker, 2007).

Downes (2006) suggests that what motivates volunteer staff to produce OER is the desire that their work be used and shared, and ultimately improved. In other cases other personal motivations are involved. Professors might derive personal benefits from contributing their work, to secure tenure, promotion or professional recognition.

\section{Motivations of institutions}

Table 6 provides the motivations of institutions to participate in OER projects that were identified in the literature.

Table 6 Motivations of institutions to participate in OER projects

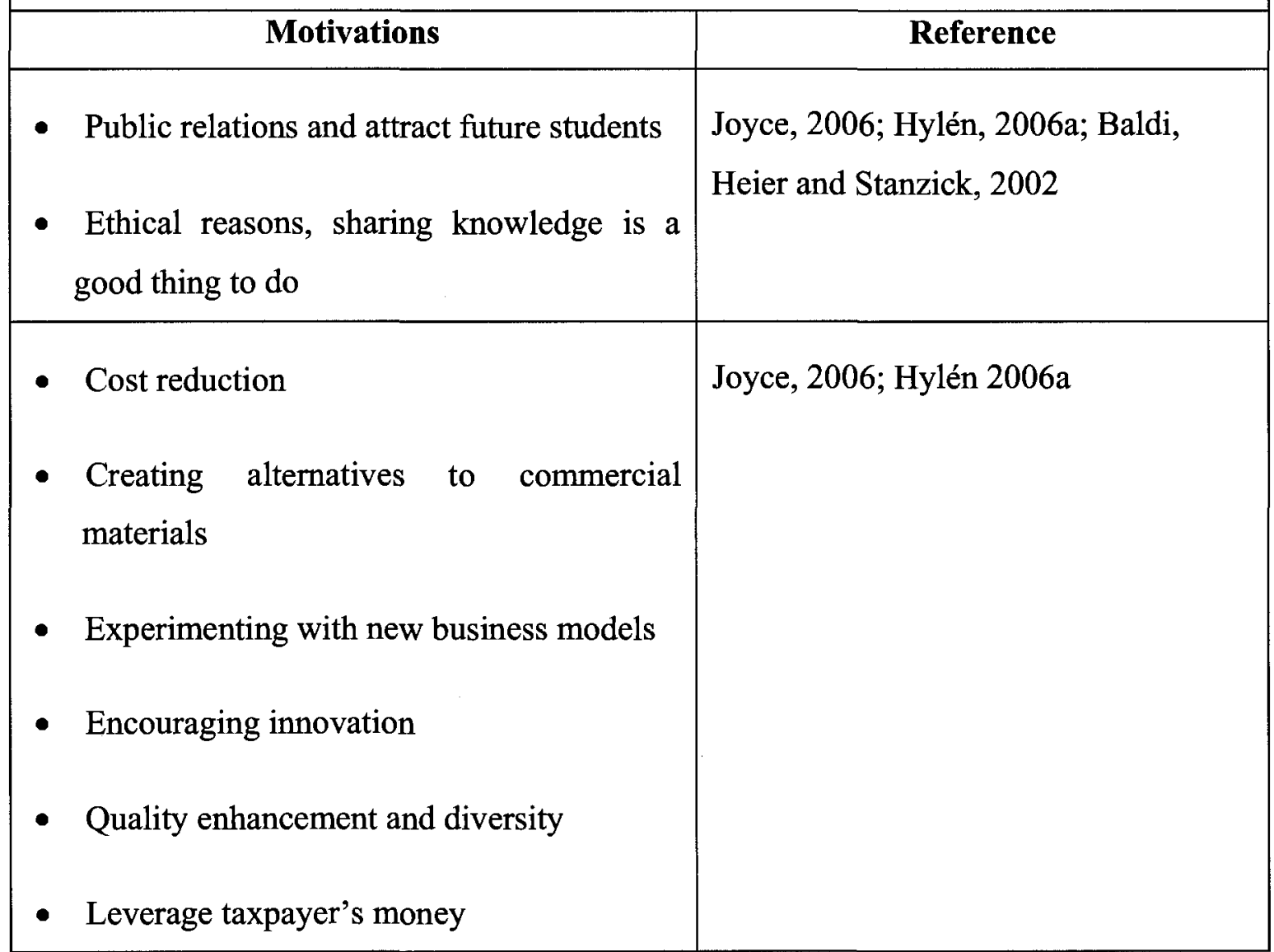


Joyce (2006) suggests that a motivation for academic institutions to provide OER is to showcase the institution's courses to prospective, current and former students. In addition, institutions may be motivated to reduce costs by relying on OER materials for teaching and learning, rather than on commercially produced content. The use of OER reduces the dependence on commercial textbooks and ensures a wider variety of academic perspectives.

There is also a desire from institutions to experiment with new business models based on OER and to generate new revenue streams for the institutions. In terms of innovation, the wider sharing of OER encourages the exchange of new ideas and innovations that would not occur in a closed, proprietary context. Hence, it is possible that the quality of individual teaching and learning resources might be improved given the increased visibility of the content (Joyce, 2006; Hylén 2006a).

Finally, there is the perception that publicly funded institutions have a moral and ethical obligation to maintain and promote social and academic freedom and leverage taxpayer's money by allowing free sharing of resources (Joyce, 2006; Hylén, 2006a).

Baldi, Heier and Stanzick (2002) describe the motivations to create the MIT OCW. One motivation is to showcase quality of teaching and attract prospective students. In addition, there is the altruistic desire to disseminate knowledge and promote the usage of the content by other universities, especially in developing countries. Finally, there is a desire for reputation and status associated with the establishment of the MIT OCW. 


\subsubsection{OSS}

$\underline{\text { Motivation of individuals }}$

The body of research around motivations for contributions to OSS projects is vast and continues to grow as a core research area on the OSS. Von Krogh and von Hippel (2006) present a literature review on the state of the art in the research on motivations of project contributors of OSS. The research about motivations of project contributors ranges from individual incentives to impact of firms' participation on individual motives, impact of community participation on individual motives and relationships between incentives and technical design of OSS (von Krogh \& von Hippel, 2006).

Lerner and Tirole (2002) argue that the motivations of individuals to contribute in OSS projects can be explained through economic theories. They analyze two kinds of incentives: career concern incentives for example job offers that might rise from the developers' participation in OSS projects and ego gratification incentives that arise from a desire for peer recognition. Lerner and Tirole (2002) name these two kinds of incentives "signalling incentives" and provide evidence from four OSS projects consistent with these incentives.

Bonaccorsi and Rossi (2003) find that intellectual gratification, prestige and visibility and the need to fill an unfilled market are recurrent motives for individuals contributing to OSS. Moreover, Bonaccorsi and Rossi (2004) divide the motivations of programmers to contribute to OSS projects into three groups: economic, social and technological. Table 7 presents the motivations within each group. 
Table 7 Motivations of individuals to contribute to OSS projects (Bonaccorsi \& Rossi, 2004)

\begin{tabular}{|c|c|}
\hline Motivation area & Motivation \\
\hline Economic & $\begin{array}{l}\text { - Monetary reward } \\
\text { - Low opportunity costs } \\
\text { - Gaining reputation among peers } \\
\text { - Gaining future career benefits }\end{array}$ \\
\hline Social & $\begin{array}{l}\text { - Fun to program } \\
\text { - Altruism } \\
\text { - Sense of belonging to the community } \\
\text { - Fight against proprietary software }\end{array}$ \\
\hline Technological & $\begin{array}{l}\text { - Contributions and feedback from the community } \\
\text { - Working with a bleeding-edge technology } \\
\text { - Scratching a personal itch }\end{array}$ \\
\hline
\end{tabular}

\section{Motivations of firms}

Lerner and Tirole (2001) explain that firms participate in OSS projects for profit reasons.

Firms expect to benefit from their expertise in OSS by providing complementary services and products that are not supplied efficiently by the open source community. Firms also participate in OSS projects for public relations reasons and to learn about the strengths and weaknesses of the OSS development process (Lerner \& Tirole, 2002). 
Bonaccorsi and Rossi (2004) organize the motivations of firms to participate in OSS projects into three groups: economic, social and technological. Table 8 presents the motivations organized in these groups.

\begin{tabular}{|c|c|}
\hline & firms to partic \\
\hline Motivation area & Motivation \\
\hline Economic & $\begin{array}{l}\text { - Being independent of the price and licensing policies of } \\
\text { the large software companies } \\
\text { - Making money on complementary services } \\
\text { - Obtaining indirect revenue by selling related products } \\
\text { - Hiring good IT specialists }\end{array}$ \\
\hline Social & $\begin{array}{l}\text { - Conforming to the values of the OSS community } \\
\text { - Sharing code and knowledge with the community } \\
\text { - Thinking that software should not be a proprietary good }\end{array}$ \\
\hline Technological & $\begin{array}{l}\text { - Exploiting feedback and contributions from developers of } \\
\text { the OSS community } \\
\text { - Cutting hardware costs } \\
\text { - Promoting standardization } \\
\text { - Addressing security issues }\end{array}$ \\
\hline
\end{tabular}

Bonaccorsi and Rossi (2004) compared motivations between firms and individuals and found significant differences between the two. Firms emphasize economic and 
technological reasons and not the social motivations that drive individuals (Bonaccorsi \& Rossi, 2004).

Yang (2006) analyzed company's motives for establishing and participating in OSS projects of fourteen software companies in North America and Europe. The results suggest that the two main motives for establishing OSS projects are: i) to attract developers in order to make better software and, ii) seed the market for a new company and accelerate product acceptance in a new market.

Table 9 presents the motives for establishing and participating in OSS projects identified by Yang (2006). 
Table 9 Motivations of firms to establish and participate in OSS (Yang, 2006) Motives for establishing OSS projects

- Attract developers to make better software

- Seed the market for a new company and accelerate product acceptance in new market

- Solve an advanced problem for existing software

- Provide customers an alternative to proprietary software

- Maintain product that is not core to the existing business

- Satisfy and retain partners and customers

Motives for participating in OSS projects

- Reduce development costs

- Attract developers to make better software

- Reduce pre-sales costs

- Increase market share of existing product

- Obtain feedback from diverse communities

- Offer more options and features faster

- Improve product interoperability

- Set standard

- Accelerate the exploration of new ways of doing things

- Accelerate the incorporation of innovation into product

- Satisfy and retain partners and customers

- Develop expert user base

- Reduce risk of technology lock-in

\subsection{Governance}

Governance has different meanings depending on the context the term is applied. In private sector applications, governance refers to a "regime of rules which ensures freedom of entry into the market, access to information and the sanctity of contracts" (Lynn, Heinrich \& Hill, 2001). 
In the public sector, governance is defined as regimes of laws, rules, judicial decisions, and administrative practices that constrain, prescribe, and enable the provision of publicly supported goods and services (Lynn et al., 2001).

In the organizational control literature, governance is assumed as a toolbox for control, supervision and monitoring that works to achieve the objectives of all group members (Lattemann \& Stieglitz, 2005).

\subsubsection{OER}

Keats (2003) distinguishes between two extremes of open content creation and sharing: centralized publishing and community of construction. Keats (2003) suggests that "users are likely to place greater value on content when they have been included its planning and development, although the line may be less steep when the publishing organization is one of substantial international stature".

Table 10 compares OER projects that use centralized publishing and community of construction, in terms of their organizational structure, involvement of users, and the extent to which new development partners are welcome (Keats, 2003).

\begin{tabular}{|l|l|l|}
\hline \multicolumn{2}{|c|}{$\begin{array}{c}\text { Table 10 } \\
\text { production-consumer model for content }\end{array}$} & \multicolumn{1}{c|}{ Characteristics of OER propects the co-production and } \\
\hline & \multicolumn{1}{|c|}{ Producer-consumer } & \multicolumn{1}{c|}{ Co-production } \\
\hline $\begin{array}{l}\text { Organizational } \\
\text { structure }\end{array}$ & $\begin{array}{l}\text { One or more experts create } \\
\text { content as part of a centrally } \\
\text { managed structure }\end{array}$ & $\begin{array}{l}\text { One or more experts create content } \\
\text { as a part of a decentralised } \\
\text { management structure }\end{array}$ \\
\hline $\begin{array}{l}\text { Volunteer } \\
\text { contributors } \\
\text { welcome }\end{array}$ & Exclusive & Inclusive \\
\hline $\begin{array}{l}\text { Involvement of } \\
\text { main users }\end{array}$ & $\begin{array}{l}\text { Expected users are not involved } \\
\text { in content development }\end{array}$ & $\begin{array}{l}\text { Expected users are actively } \\
\text { involved in content development }\end{array}$ \\
\hline
\end{tabular}


The co-production model may involve numerous partnerships and may involve volunteer contributors (Organization for Economic Co-operation and Development, 2007)

\subsubsection{OSS}

Markus (2007) and O'Mahony (2007) define governance of OSS as "the means of achieving the direction, control and coordination of wholly or partially autonomous individuals and organizations on behalf of an OSS development project to which they jointly contribute".

The literature on governance of OSS projects is based on case studies and cross sectional and quantitative analyses (Markus, 2007). However, the lack of a common definition of governance across this body of literature makes it challenging to assess and compare different research findings (Markus, 2007).

Some researchers provide categories of OSS governance from the existing OSS literature (de Laat, 2007; Markus, 2007; Lattemann \& Stieglitz, 2005) and one provides categories of governance from field research of OSS communities (O'Mahony, 2007). These categories serve as a framework to assess OSS projects and conduct research on contexts to which the notions of openness and community management have been applied (de Laat, 2007; Markus, 2007; O’Mahony, 2007; Lattemann \& Stieglitz, 2005).

Table 11 provides the dimensions and constructs used to describe governance in the OSS literature. 


\begin{tabular}{|c|c|}
\hline Table 11 & nsions of governance in the OSS literature \\
\hline Governance dimension & Related constructs on the literature \\
\hline Division of roles & $\begin{array}{l}\text { - } \text { Community management (Markus, 2007) } \\
\text { - Division of roles (de Laat, 2007) } \\
\text { - Division of labour (Lattemann \& Stieglitz, 2005) } \\
\text { - Pluralism (O'Mahony, 2007) }\end{array}$ \\
\hline $\begin{array}{l}\text { How to enter and scale in the } \\
\text { community }\end{array}$ & $\begin{array}{l}\text { - } \text { Community management (Markus, 2007) } \\
\text { - Representation (O’Mahony, 2007) } \\
\text { - Training and indoctrination (de Laat, 2007) }\end{array}$ \\
\hline Leadership of the project & $\begin{array}{l}\text { - Community management (Markus, 2007) } \\
\text { - Autocracy/democracy (de Laat, 2007) }\end{array}$ \\
\hline $\begin{array}{l}\text { Decisions for code inclusion } \\
\text { and code release }\end{array}$ & $\begin{array}{l}\text { - Software development process (Markus, 2007) } \\
\text { - Delegation of decision making (de Laat, 2007) } \\
\text { - Decentralized decision making (O'Mahony, 2007) }\end{array}$ \\
\hline $\begin{array}{l}\text { Rules and tools for } \\
\text { communication }\end{array}$ & $\begin{array}{l}\text { - Use of information tools (Markus, 2007) } \\
\text { - Formalization (de Laat, 2007) } \\
\text { - Coordination (Lattemann \& Stieglitz, 2005) }\end{array}$ \\
\hline $\begin{array}{l}\text { Intellectual property license } \\
\text { and legal organization } \\
\text { structure }\end{array}$ & $\begin{array}{l}\text { - Ownership of assets (Markus, 2007) } \\
\text { - Independence (O'Mahony, 2007) } \\
\text { - Structure (Lattemann \& Stieglitz, 2005) }\end{array}$ \\
\hline
\end{tabular}




\begin{tabular}{|l|l|}
\hline Goals of the project & $\begin{array}{l}\text { - Chartering of the project (Markus, 2007) } \\
\text { - Focus (Lattemann \& Stieglitz, 2005) }\end{array}$ \\
\hline $\begin{array}{l}\text { Conflict resolution } \\
\text { management }\end{array}$ & $\begin{array}{l}\text { - Pluralism (O'Mahony, 2007) } \\
\text { Conflict resolution, rule changing (Markus, 2007) }\end{array}$ \\
\hline $\begin{array}{l}\text { Level of access for } \\
\text { developers to contribute }\end{array}$ & - Autonomous participation (O'Mahony) \\
\hline Level of code modularization & - Modularization (de Laat, 2007) \\
\hline
\end{tabular}

de Laat (2007) draws on Mintzberg (1979) structuring of organizations to identify six categories of tools used by OSS projects for internal governance, including coordination and control of OSS project work to achieve optimal outcomes. These categories are: modularization, division of roles, delegation of decision-making, training and indoctrination, formalization and autocracy/democracy.

Modularization is a basic mechanism of OSS projects that allows coordination among an increasing number of participants. Division of roles is utilized to associate and differentiate access to project files. Delegation of decision making refers to the decisions related to the start of new activities, methods to be used, integration of modules into new releases, up to community-wide issues. Training and indoctrination refers to the entry requirements to the OSS projects. Formalization refers to the formal tools and procedures to coordinate globally distributed virtual contributors. Finally, autocracy/democracy refers to the kind of leadership of the project: self appointed or decided by community members (de Laat, 2007). 
Markus (2007) distinguishes two types of views on OSS governance: monolithic and multidimensional. In the monolithic view, OSS governance is portrayed as a single, unified phenomenon, most frequently defined as OSS licensing mechanisms. Using a multidimensional perspective, OSS projects are analyzed across many types and variations of governance mechanisms within the broad category of OSS projects.

Markus (2007) finds three different purposes for OSS governance in the literature on open source governance: i) solving collective action problems, ii) solving coordination problems in software development and, iii) creating a better climate for contributors.

Table 12 presents Markus' classification of the elements of OSS governance into six main categories.

\begin{tabular}{|l|l|}
\hline \multicolumn{1}{|c|}{ Table 12 } & \multicolumn{1}{c|}{ OSS governance categories (Markus, 2007) } \\
\hline \multicolumn{1}{|c|}{ Category } & \multicolumn{1}{c|}{ Description } \\
\hline Ownership of assets & $\begin{array}{l}\text { Includes intellectual property licenses and formal legal } \\
\text { organization structures (e.g., foundations) }\end{array}$ \\
\hline Chartering the project & $\begin{array}{l}\text { Refers to statements of division about the goals of the } \\
\text { project, e.g. what the software product should look like. }\end{array}$ \\
\hline Community management & Rules about membership and roles \\
\hline $\begin{array}{l}\text { Content development } \\
\text { process }\end{array}$ & $\begin{array}{l}\text { Structures and rules involving development tasks, such as } \\
\text { release control, management of changes, etc. }\end{array}$ \\
\hline Conflict resolution & $\begin{array}{l}\text { Rules and procedures for resolving conflict and creating } \\
\text { new rules }\end{array}$ \\
\hline $\begin{array}{l}\text { Use of information and } \\
\text { tools }\end{array}$ & $\begin{array}{l}\text { Rules about how information will be communicated and } \\
\text { managed and how repositories will be used }\end{array}$ \\
\hline
\end{tabular}

O'Mahony (2007) analyzes how a community managed modes of governance differs from other forms. The OSS frame has been adapted and diffused since the term open source was created in 1998, therefore, renewed attention should be paid to the principles that constitute the community-managed mode of governance. To this end, O'Mahony (2007) identifies five core principles of the community managed governance model: 
independence, pluralism, representation, decentralized decision-making and autonomous participation.

Table 13 presents the principles of the community managed governance model advanced by O’Mahony (2007).

\begin{tabular}{|c|c|c|}
\hline Table 13 & rinciples of the comm & $\begin{array}{l}\text { tity managed governance model (O'Mahony, } \\
\text { 007) }\end{array}$ \\
\hline Principle & Definition & Evaluation \\
\hline Independence & $\begin{array}{l}\text { Governance is } \\
\text { independent of any } \\
\text { one sponsor }\end{array}$ & $\begin{array}{l}\text { - Diversification of material support } \\
\text { - Decision-making structure } \\
\text { - Independence from employment relations }\end{array}$ \\
\hline Pluralism & $\begin{array}{l}\text { Governance preserves } \\
\text { multiple and/or } \\
\text { competing } \\
\text { approaches, methods, } \\
\text { theories or points of } \\
\text { view }\end{array}$ & $\begin{array}{l}\text { - Diversity of contributors } \\
\text { - Management of conflict } \\
\text { - Determination of leadership- processes } \\
\text { and turnover }\end{array}$ \\
\hline Representation & $\begin{array}{l}\text { Contributing members } \\
\text { can be represented in } \\
\text { community-wide } \\
\text { decisions }\end{array}$ & $\begin{array}{l}\text { - Membership structure and rights } \\
\text { - Ways in which those in authority are } \\
\text { accountable to contributing members } \\
\text { - Degree to which members can exercise } \\
\text { voice on community members }\end{array}$ \\
\hline $\begin{array}{l}\text { Decentralized } \\
\text { decision- } \\
\text { making }\end{array}$ & $\begin{array}{l}\text { Some degree of } \\
\text { decision-making is } \\
\text { decentralized }\end{array}$ & $\begin{array}{l}\text { - How contributors gain code commit } \\
\text { rights } \\
\text { - How contributors gain access to the } \\
\text { project's decision-making structure } \\
\text { - Degree to which project communications } \\
\text { and activities are publicly available }\end{array}$ \\
\hline $\begin{array}{l}\text { Autonomous } \\
\text { participation }\end{array}$ & $\begin{array}{l}\text { Welcomes } \\
\text { participation and } \\
\text { allows members to } \\
\text { contribute on their } \\
\text { own terms }\end{array}$ & $\begin{array}{l}\text { - Newcomer joining rate } \\
\text { - Newcomer socialization opportunities } \\
\text { - Rate of idea generation }\end{array}$ \\
\hline
\end{tabular}


Lattemann and Stieglitz (2005) identify coordination and controlling mechanism for the governance in open source communities. They distinguish four governance tools to analyze the success of software development in specific life stages. These tools are: focus, structure, division of labour, coordination.

Focus refers to the main objective of the OSS project. Lattemann and Stieglitz (2005) distinguish between changing objectives according to the stage of the project. For instance, at the early stages of development, OSS projects focus on idea generation because the success of the project is highly dependent on the quality of the initial idea. As the project matures the objectives change towards expansion, stability and adoption (Lattemann \& Stieglitz, 2005).

Structure refers to the organization of the project and the level of formality and centralization that it bears. At the early stages of the project the structure tends to be completely informal, meaning that no hierarchy is exercised. However, as the project grows it becomes more formal and centralized, and then turns to a less formal and decentralized structure towards the decline or revival of the project (Lattemann \& Stieglitz, 2005).

Division of labour is very general at the early stages of an OSS project. As the project grows it becomes highly specialized (Lattemann \& Stieglitz, 2005).

Coordination mechanisms vary from informal or one-on-one at the early stages of the project, to the adoption and dependence on communication tools to discuss further software development and optimization (Lattemann \& Stieglitz, 2005). 


\section{Leadership of OSS projects}

Most successful OS projects display a clear hierarchical organization (Bonaccorsi \& Rossi, 2003), although the roles are not assigned at the start of the project. The authority of the project leaders or core development group arises naturally from the bottom up as a result of the contributions to a common goal. As a result, contributions are highly concentrated among a few authors (Bonaccorsi \& Rossi, 2003).

Leadership plays an important role in an OS project. Leaders select the most suitable contribution among the ones proposed by the contributors for an existing problem (Bonaccorsi \& Rossi, 2003). Moreover, the core development group does not carry out the bulk of the coordination effort. Contributors are free to focus on the problems that best fit their own interests and capabilities (Bonaccorsi \& Rossi, 2003).

The initial leader must produce a critical mass of code to which programmers in the community can react (Lerner \& Tirole, 2002). In addition, the leader should perform only a small portion of the programming in order to leave challenges that can attract additional programmers (Lerner \& Tirole, 2002). This was a recurrent characteristic of the cases studied by Lerner and Tirole (2002), which included the successful OSS projects Apache, Perl, Linux and Sendmail.

Leaders of OS projects share characteristics. Most leaders are the programmers who developed the initial code for the project or make an important contribution in the early stages of the project (Lerner \& Tirole, 2002). This initial experience was found to be important in order to build credibility to manage the project (Lerner \& Tirole, 2002). Recommendations of the leaders tend to be followed by the vast majority of programmers 
working on the project, although the leader has no formal authority to instruct any programmer to do a specific task.

Successful leaders should state objectives aligned with the programmers interests and not biased by commercial or personal interests. Moreover, the decision making process to accept proposed changes should be clear and transparent (Lerner \& Tirole, 2002).

\subsection{IP protection}

\subsubsection{OER}

The Creative Commons license is the best known and most used license for content (Organization for Economic Co-operation and Development, 2007). Creative Commons licenses aim to make copyright content more active by ensuring that content can be reutilized with a minimum of transactional effort. Open content licensing provides a vitally important facility for sharing and reshaping knowledge in the name of culture, education and innovation (Organization for Economic Co-operation and Development, 2007).

\subsubsection{OSS}

O'Mahony (2003) analyzes six OSS mature projects to identify seven tactics that community managed projects use to protect their work. Community managed projects are defined as an open source project initiated and managed by a distributed group of people who do not share a common employer. Table 14 presents the seven tactics OSS projects use to protect their work as identified by O’Mahony (2003). 


\begin{tabular}{|l|l|}
\hline \multicolumn{1}{|c|}{ Table 14 Tactics OSS projects use to protect their work (O'Mahony, 2003) } \\
\hline \multicolumn{1}{|c|}{ Tactic } & \multicolumn{1}{c|}{ Purpose } \\
\hline $\begin{array}{l}\text { Licensing terms that restrict } \\
\text { proprietary appropriation }\end{array}$ & $\begin{array}{l}\text { Guard against free rider problems associated with the } \\
\text { private provision of public goods }\end{array}$ \\
\hline Legal and normative sanctions & Encourage compliance and to enforce license terms \\
\hline Incorporate & $\begin{array}{l}\text { A legal entity (such as non profit foundations) holds } \\
\text { intellectual property and protect volunteer } \\
\text { contributors from individual liability }\end{array}$ \\
\hline $\begin{array}{l}\text { Transfer individual property } \\
\text { rights to a foundation }\end{array}$ & $\begin{array}{l}\text { Secure legal protections for the code, limit individual } \\
\text { liability and improve their ability to pursue } \\
\text { enforcement actions }\end{array}$ \\
\hline $\begin{array}{l}\text { Trademark brands and logos } \\
\text { designed to represent their work }\end{array}$ & $\begin{array}{l}\text { Ensure that the project will be uniquely distinguished } \\
\text { and to prevent others from confusing projects } \\
\text { software with other related work }\end{array}$ \\
\hline $\begin{array}{l}\text { Assign trademarks to the } \\
\text { foundation }\end{array}$ & $\begin{array}{l}\text { Avoid indiscrimate use of the project trademark by } \\
\text { corporations }\end{array}$ \\
\hline Actively protect brand & $\begin{array}{l}\text { Build co-branding relationships with firms. Co- } \\
\text { branding allows two contributing brands to the } \\
\text { product or service to be recognized, the one of the } \\
\text { firm and the one of the OSS project }\end{array}$ \\
\hline
\end{tabular}

A unique feature of the seven tactics presented in Table 14 is that the rights retained by the licensors (in this case, individuals or communities in charge of the OSS projects) are not the rights for which the tools were traditionally designed (O'Mahony, 2003). For instance, the GPL is a copyright license designed with unique distribution terms, using principles termed as "copy left". Copy left uses copyright law but it flips it over to keep software free, instead of using it as a means of privatizing the software (O'Mahony, 2003). 
O'Mahony (2003) concludes that contributors to OSS projects have interests and rights over their work and are interested in protecting their intellectual property. This argument contradicts the notion that OSS contributors give their work away.

In addition, these tactics allow OSS to stay open, remain publicly available and avoid the risks inherent with work in the public domain (O'Mahony, 2003).

\subsection{OER vs. OSS}

Remmele (2006) describes differences between OER and OSS. The communication structure of OSS (for instance through forums and mailing lists) is absent in OER. The OER communication structure is highly dispersed as opposed to as the centric form that exists in OSS (Remmele, 2006).

In addition, OER is often created in one language, and potential users are likely to speak several different languages. In contrast, software languages ease the use of OSS by anyone with computer programming knowledge (Remmele, 2006).

Baldi et al. (2002) use the OER project MIT OCW to examine similarities and differences between OCW and OSS. They identify the following differences between OCW and OSS:

- OSS is built on a common infrastructure of tools, languages and development environments; however a similar widely accepted common framework does not exist for producing OCW.

- The development of OSS is often a self-organized and distributed effort for a single product, whereas the MIT OCW project is centrally coordinated and funded by MIT. 
- OSS development involves the software user in the development process, thus creating a new governance structure. The OCW does not allow the involvement of students in the production and/or updating of the content, although feedback from them is encouraged.

- The OCW does not aim at the improvement of its quality by international cooperation, but rather to show how well made centrally developed OCW can be.

- Economic gains differ as well. Programmers can obtain economic gain by relying on efforts of others as long as they comply with the open source license. For OCW producers, the gain of reputation and organizational benefits is often not cost effective when compared with the large amount of money that is necessary to set up an OCW project.

- Open access to source code and course material fosters the exchange between people and innovation power. This makes OSS and OCW valuable to the scientific community.

Table 15 presents the similarities between OCW and OSS according to Baldi et al. (2002).

\section{Table 15 Similarities between OER and OSS (Baldi et al., 2002)}

- Ideology based on sharing knowledge with other people

- Virtual assets with codified, explicit knowledge

- Can be copied, modified and distributed at low cost

- Peer recognition is an important individual motivation to contribute

- Valuable to the scientific community because they promote innovation 
The Report on the discussion on Free and OSS for OER (2006) compares OSS and OER in several aspects:

- OSS relies on collaborative development much more so than OER. With OSS, collaborative development makes the code progressively better. Many eyes decrease the number of bugs in software. Currently, most OCW projects have top-down structures that require paid teams of experts to lead the development. In contrast, few OER rely heavily on collaborative development, although this is changing.

- There are well established tools and processes that help OSS developers produce defect free software. These tools and processes can not be used to improve OER. The quality of OER is associated with accuracy of facts and the pedagogical methods it supports while the quality of OSS is associated with errors per line of code and the fit between function and customer requirements.

- OSS and OSS share a commitment to adopt open licenses. However in practice, not all license options equally support the notions of free and open content. For example the "No Derivative Works" and "Noncommercial" restrictions available from the Creative Commons license do not allow derivative works without permission from the author or commercial usage of the content.

- OSS producers require sometimes very specialized expertise in software languages. In contrast, OER producers do not need the same type of technical expertise to modify OER.

Mora (2007) concludes that in terms of business models, the ways to make money from OER production and distribution have not emerged yet. Large companies are not making money from OER development. There is a much better understanding of how 
companies and individuals make money from OSS and their motivations to participate in OSS projects (Mora, 2007).

Table 16 identifies the differences between OER and OSS drawn from the literature.

\begin{tabular}{|c|c|c|c|}
\hline \multicolumn{4}{|c|}{ Table 16 Differences between OER and OSS } \\
\hline $\begin{array}{l}\text { Distinguishing } \\
\text { dimension }\end{array}$ & OSS & OER & Reference \\
\hline $\begin{array}{l}\text { Development } \\
\text { effort }\end{array}$ & $\begin{array}{l}\text { - Self organized } \\
\text { and not funded by } \\
\text { the project } \\
\text { - Single product } \\
\text { with several } \\
\text { interrelated } \\
\text { modules }\end{array}$ & $\begin{array}{l}\text { - Centrally } \\
\text { coordinated and } \\
\text { funded by the } \\
\text { project } \\
\text { - Several products } \\
\text { (courses) not } \\
\text { necessarily } \\
\text { interrelated }\end{array}$ & Baldi et al., 2002 \\
\hline Goals & $\begin{array}{l}\text { Aims to improve } \\
\text { code quality via } \\
\text { cooperation from } \\
\text { many } \\
\text { contributors }\end{array}$ & $\begin{array}{l}\text { Aims to showcase } \\
\text { organizational } \\
\text { capability }\end{array}$ & \\
\hline Cost to enter & - Low investment & - High investment & \\
\hline $\begin{array}{l}\text { Role of users as } \\
\text { buyers }\end{array}$ & $\begin{array}{l}\text { - Users are } \\
\text { potential buyers }\end{array}$ & $\begin{array}{l}\text { Users are not } \\
\text { potential buyers }\end{array}$ & $\begin{array}{l}\text { Report on the } \\
\text { discussion on Free }\end{array}$ \\
\hline $\begin{array}{l}\text { Quality } \\
\text { assurance }\end{array}$ & $\begin{array}{l}\text { Established tools } \\
\text { and processes to } \\
\text { produce defect } \\
\text { free software }\end{array}$ & $\begin{array}{l}\text { - Assessed by } \\
\text { different } \\
\text { stakeholders using } \\
\text { different } \\
\text { perspectives }\end{array}$ & 2006 \\
\hline $\begin{array}{l}\text { Expertise } \\
\text { required to } \\
\text { modify the asset }\end{array}$ & $\begin{array}{l}\text { Programming } \\
\text { expertise required }\end{array}$ & $\begin{array}{l}\text { Context knowledge } \\
\text { and technical know- } \\
\text { how }\end{array}$ & \\
\hline Communication & - $\begin{array}{c}\text { Highly } \\
\text { organized }\end{array}$ & - Fragmented & Remmele, 2006 \\
\hline
\end{tabular}




\begin{tabular}{|l|l|l|l|}
\hline $\begin{array}{l}\text { Development } \\
\text { environment }\end{array}$ & $\begin{array}{l}\text { - Tools and } \\
\text { languages } \\
\text { commonly used }\end{array}$ & $\bullet \begin{array}{l}\text { Custom tools and } \\
\text { languages }\end{array}$ & $\begin{array}{l}\text { Baldi et al., 2002 } \\
\text { Remmele, 2006 }\end{array}$ \\
\hline Economic gains & $\begin{array}{l}\text { Mature business } \\
\text { models for } \\
\text { companies }\end{array}$ & $\begin{array}{l}\text { Uncertainty as to } \\
\text { how to monetize }\end{array}$ & Mora, 2007 \\
\hline
\end{tabular}

\subsection{Lessons learned}

1. Dimensions used to analyzed OSS governance in the literature (e.g. intellectual property licenses and core mission of the project) can be used to analyze assets developed collaboratively under open licenses such as OER.

2. There are two predominant approaches to produce OER: co-production and production-consumer model (Organization for Economic Cooperation and Development, 2007). They differ in terms of the organization and governance structure and the nature of user involvement (Keats, 2003).

3. There is a lack of research on the governance of OER projects. Previous research has focused on the motivations of individuals and institutions to use and produce OER but has not analyzed the governance of OER projects.

4. Research on OSS governance presents several dimensions for analysis and a widely accepted definition for constructs does not exist. Several authors have attempted to provide a framework for OSS governance (Laat, 2007; Markus, 2007; O'Mahony, 2007; Lattemann \& Stieglitz, 2005) and have encouraged their use in other contexts where the notions of openness and community management are important. 
5. The OSS literature presents tactics used by community managed OSS projects (O'Mahony, 2003) to protect their work. This set of tactics can be used as a benchmark to compare the tactics used by OER projects.

6. OER can include but are not limited to open content. OER can include OSS used to facilitate OER, as well as the distribution licenses used for OER content.

7. There is little empirical research on the differences and similarities between OER and OSS. The extant literature compares OER projects that utilize the producerconsumer model for content development such as the MIT OCW, with OSS. There are currently other approaches different from the one used by MIT OCW to produce OER and these have not been compared with OSS. Examples of such OER projects are Connexions ${ }^{8}$ and OpenLearn ${ }^{9}$.

8. Similarities between OER and OSS relate to motivations and the free and reusable nature of the assets by virtue of the licenses. Differences are related to how the development effort and collaboration is organized, and the involvement of firms in OSS projects, which is not as high as with OER projects.

9. The body of literature around OSS is vast and mature. This is not the case for the OER literature. Early research on OSS sought to understand the motivations of individuals and firms to participate on OSS projects. OER seems to be following the same path. An empirical research on OER (Organization for Economic Cooperation and Development, 2007) includes a study of the motivations of academics to contribute to OER institutional projects.

\footnotetext{
${ }^{8}$ http://cnx.org/

${ }^{9} \mathrm{http}$ ://openlearn.open.ac.uk/
} 


\section{RESEARCH METHOD}

This chapter describes the method used to produce the deliverables of this research. It is organized into three sections. Section 3.1 describes the unit of analysis. Section 3.2 identifies the study period. Section 3.3 describes the research method and the steps undertaken to answer the research questions and produce observations about OER.

\subsection{Unit of analysis}

The unit of analysis is an OER project that produces content, offers it openly on the Internet, and was established by an academic institution or a non profit organization.

\subsection{Study period}

The data were collected from April to June 2008. OER projects that were established from January 2001 to March 2008 were selected for the study. January 2001 was selected as the start date because a representative OER project, Wikipedia, was launched in 2001 and it is unlikely that another representative OER projects was established before this date.

Projects up to March 2008 were included to establish a limit for the researcher's data collection.

\subsection{Method}

This study is an inductive research using case studies (Eisenhardt, 1989; Yin, 1989). Case study research is applicable when little is known about the phenomenon and the topic under study is in the early stages of research (Eisenhardt, 1989). Research around OER is still in its early stages, therefore there is little research on the motives of 
institutions to establish the projects, governance, or the ways OER projects protect their content.

Table 17 provides the steps of the research method. For each dominant activity in the method, the rationale for the activity is identified in the last column of Table 17.

\begin{tabular}{|c|c|c|}
\hline \multicolumn{2}{|r|}{ Table 17} & Research method \\
\hline No & Activity & Rationale for the activity \\
\hline 1 & Define objectives of the research & $\begin{array}{l}\text { Focus efforts and provides a reference } \\
\text { for construct measures } \\
\text { - Set goals for research completion }\end{array}$ \\
\hline 2 & $\begin{array}{l}\text { Extract governance dimensions } \\
\text { from the OER and OSS literature }\end{array}$ & $\begin{array}{l}\text { Specification of dimensions and criteria } \\
\text { to identify differences in the governance } \\
\text { used by OER projects that utilize the co- } \\
\text { production and producer-consumer model }\end{array}$ \\
\hline 3 & $\begin{array}{l}\text { Identify sample of experts and } \\
\text { prepare and distribute } \\
\text { questionnaire to identify } \\
\text { uniqueness of OER }\end{array}$ & $\begin{array}{l}\text { Find the uniqueness of OER relative to } \\
\text { OSS in terms of: i) motives for } \\
\text { establishing the projects, ii) governance } \\
\text { and, iii) IP protection }\end{array}$ \\
\hline 4 & Identify sample of OER projects & $\begin{array}{l}\text { Define population of OER projects from } \\
\text { where to draw the sample }\end{array}$ \\
\hline 5 & $\begin{array}{l}\text { Select first wave of OER projects } \\
\text { randomly }\end{array}$ & $\begin{array}{l}\text { Random selection was used because } \\
\text { previous research did not provide a } \\
\text { reference to select the initial cases using } \\
\text { theoretical sampling }\end{array}$ \\
\hline
\end{tabular}




\begin{tabular}{|c|c|c|}
\hline 6 & $\begin{array}{l}\text { Collect data from the } \\
\text { questionnaires to OER and OSS } \\
\text { experts and from the first wave of } \\
\text { OER projects }\end{array}$ & $\begin{array}{l}\text { Contact experts in OER and OSS and } \\
\text { while waiting for their responses collect } \\
\text { data on from the first wave of OER } \\
\text { projects }\end{array}$ \\
\hline 7 & Analyze data & $\begin{array}{l}\text { Categorize motives for establishing OER } \\
\text { projects and tactics to protect content } \\
\text { Identify differences in the governance } \\
\text { used by OER projects that utilize the co- } \\
\text { production and the production-consumer } \\
\text { model according to the criteria established } \\
\text { Categorize responses from questionnaire } \\
\text { to experts }\end{array}$ \\
\hline 8 & $\begin{array}{l}\text { Select second wave of OER } \\
\text { projects randomly and collect } \\
\text { data }\end{array}$ & $\begin{array}{l}\text { Random selection was used because } \\
\text { previous research did not provide a } \\
\text { reference to select the initial cases using } \\
\text { theoretical sampling }\end{array}$ \\
\hline 9 & $\begin{array}{l}\text { Select third wave of OER } \\
\text { projects using theoretical } \\
\text { sampling and collect data }\end{array}$ & $\begin{array}{l}\text { Focus on OER projects that show } \\
\text { potential to extend and refine initial } \\
\text { findings }\end{array}$ \\
\hline 10 & $\begin{array}{l}\text { Identify motives for establishing } \\
\text { OER projects, differences in } \\
\text { governance used by OER projects } \\
\text { that utilize the co-production and } \\
\text { producer-consumer model and } \\
\text { tactics used to protect the content }\end{array}$ & - Answer first three research questions \\
\hline 11 & Identify uniqueness of OER & - Answer fourth research question \\
\hline
\end{tabular}




\subsubsection{Define objectives of the research}

The objective of this research is to answer four research questions:

1. What are the motives of academic and non profit institutions for establishing OER projects?

2. What are the differences between the governance used by OER projects that utilize the co-production and the producer-consumer model for content development?

3. How do OER projects protect their content?

4. What is unique about OER when compared to OSS in terms of: i) motives for establishing the projects, ii) governance of the project and content production and, iii) IP protection?

\subsubsection{Extract governance dimensions from the OER and OSS literature}

Table 18 presents the criteria used to establish differences between the governance used by OER projects that utilize the co-production and the producer-consumer model for content development and the data used to measure the governance dimensions. 


\begin{tabular}{|c|c|c|c|c|}
\hline \multicolumn{2}{|c|}{ Table 18} & \multicolumn{3}{|c|}{$\begin{array}{l}\text { Criteria for establishing differences in the governance of OER } \\
\text { projects }\end{array}$} \\
\hline No. & $\begin{array}{l}\text { Governance } \\
\text { dimension }\end{array}$ & Variable & $\begin{array}{c}\text { Qualitative } \\
\text { value of the } \\
\text { variables }\end{array}$ & Criteria \\
\hline 1 & $\begin{array}{l}\text { Organization } \\
\text { al structure }\end{array}$ & $\begin{array}{l}\text { Content } \\
\text { publishing }\end{array}$ & $\begin{array}{l}\text { - Staff } \\
\text { - Contributors }\end{array}$ & $\begin{array}{l}\text { Staff from the organizations in } \\
\text { charge of content publication or } \\
\text { contributors in charge }\end{array}$ \\
\hline 2 & $\begin{array}{l}\text { Participation } \\
\text { of volunteer } \\
\text { contributors }\end{array}$ & $\begin{array}{l}\text { Participation } \\
\text { of volunteer } \\
\text { contributors }\end{array}$ & $\begin{array}{l}\text { - } \text { Restricted } \\
\text { - Partially } \\
\text { restricted } \\
\text { - Unrestricted }\end{array}$ & $\begin{array}{l}\text { Restricted: volunteers can not } \\
\text { contribute content to the project } \\
\text { Partially restricted: volunteers } \\
\text { must meet criteria established by } \\
\text { the project in order to contribute } \\
\text { Unrestricted: volunteers can } \\
\text { contribute with no restrictions }\end{array}$ \\
\hline 3 & Partnerships & $\begin{array}{l}\text { Number of } \\
\text { partnerships }\end{array}$ & $\begin{array}{l}\text { - High (five or } \\
\text { more) } \\
\text { - Low (less } \\
\text { than five) }\end{array}$ & $\begin{array}{l}\text { Number of partnerships with } \\
\text { foundations, firms and/or } \\
\text { research institutions. }\end{array}$ \\
\hline 4 & $\begin{array}{l}\text { Intellectual } \\
\text { property } \\
\text { license }\end{array}$ & $\begin{array}{l}\text { Content } \\
\text { license }\end{array}$ & $\begin{array}{l}\text { - Non } \\
\text { restrictive } \\
\text { - Partially } \\
\text { restrictive } \\
\text { - Restrictive }\end{array}$ & $\begin{array}{l}\text { Non restrictive: only attribution } \\
\text { to authors required } \\
\text { Partially restrictive: derivative } \\
\text { work under same license } \\
\text { Restrictive: commercial use not } \\
\text { allowed }\end{array}$ \\
\hline 5 & Core mission & $\begin{array}{l}\text { Core mission } \\
\text { of the project }\end{array}$ & $\begin{array}{l}\text { - General } \\
\text { - Specialized }\end{array}$ & $\begin{array}{l}\text { General: e.g. increase access to } \\
\text { education worldwide } \\
\text { Specialized: e.g. aims to measure } \\
\text { benefit of online courses }\end{array}$ \\
\hline
\end{tabular}

The following governance dimensions were selected from the OER literature: i) organizational structure, ii) participation of volunteer contributors and, iii) partnerships. These dimensions were extracted from the OER literature (Keats, 2003; Organization for Economic Co-operation and Development, 2007) and were selected because they are 
used to establish differences between OER projects that utilize the co-production and the producer-consumer model for content development.

The OER literature emphasizes these three governance dimensions to compare OER projects that utilize the co-production and the producer-consumer model for content development. Other governance dimensions were selected from a list of ten dimensions identified in the OSS literature and described in Table 11. Two governance dimensions were selected and adapted to the context of OER projects by the researcher: i) intellectual property licenses and ii) core mission. These two dimensions were selected based on the data available from the sources of information used in this research.

\subsubsection{Identify experts and prepare questionnaire to identify uniqueness of OER}

The experts selected to identify the uniqueness of OER relative to OSS were chosen using two steps:

\section{$\underline{\text { Step } 1}$}

A project established to analyze the impact of OER and OSS on education was identified during the literature review process. The name of the project is "OSS and OER in Education Series", established by the group Terra Incognita from Penn State world campus. The individuals included in the list of 11 contributors were asked to identify the uniqueness of OER relative to OSS. 


\section{$\underline{\text { Step } 2}$}

Each contributor contacted was asked to identify other experts in OER and OSS that they know about and were not included in the initial list. These additional experts were contacted to participate in the study.

An email was prepared to approach the experts with questions about the uniqueness of OER relative to OSS. The wording of the email used to collect data on the uniqueness of OER is:

“Dear Sir/Madam:

I am a graduate student at Carleton University in Ottawa Canada. I am doing my mater's thesis titled: "Open Educational Resources: motivations, governance and content protection". As a part of my literature review, I have identified similarities and differences between OER and OSS. For the purposes of my research, I am interested in finding the uniqueness of OER relative to OSS in terms of: i) motives for establishing the projects, ii) governance and, iii) IP protection.

Given your expertise in OER and OSS I need your help to identify what is unique to OER when compared to OSS, by answering the following questions:

i) In terms of the motives for establishing OER and OSS projects. What motivations do you consider are only present in OER projects relative to OSS projects?

ii) Which aspects of the governance of the project and content production do you think are unique to OER when compared to OSS? 
iii) In terms of the ways OER/OSS projects protect their IP (content for OER projects and code for OSS projects). Which tactics for IP protection used in OER do you consider are unique relative to OSS?

If you prefer, I can contact you by phone at any time, any day that you are available to an swer these questions. I would only need your contact information.

I greatly appreciate your cooperation. Thank you."

\subsubsection{Identify sample of OER projects}

A list of OER projects was produced using information on: i) the wiki of the UNESCOInternational Institute for Educational Planning (IIEP) community of Interest in Open Educational Resources ${ }^{10}$, ii) OER index ${ }^{11}$, iii) 80 OER tools for publishing and development Initiatives ${ }^{12}$ and, iv) list of OCW from the website iberry.com ${ }^{13}$.

After a list of OER projects was produced, the following steps were undertaken to select the sample:

\section{Step 1}

Organize the list of projects into two groups: co-production and producer-consumer models for content development, according to the level of integration of users in the production process (Organization for Economic Co-operation and Development, 2007).

\footnotetext{
${ }^{10} \mathrm{http} / / /$ oerwiki.iiep-unesco.org

${ }^{11} \mathrm{http}: / / \mathrm{cwr}$.unitar.edu.my/file.php/1/Index.htm

$12 \mathrm{http}$ ://oedb.org/library/features/80-oer-tools

${ }^{13} \mathrm{http}: / /$ iberry.com/cms/AcOCW.htm
} 
To decide to which group an OER project belongs, the researcher examined the sections "about" and "frequently asked questions" of the projects websites. If the content is solely produced by the institution, the OER project belonged to the producer-consumer group. If end users are allowed to modify or add content to the project's repositories, it belonged to the co-production group.

\section{$\underline{\text { Step } 2}$}

Projects' websites were examined to determine whether they were established by an academic institution or a non profit organization and if they were launched from January 2002 until March 2008. The projects' websites sections "home", "about", "history" and "frequently asked questions" were used to draw this information. Projects with no available information in English were discarded from the list. A list of eligible OER projects was produced to be part of the sample.

\subsubsection{Select waves of OER projects}

Cases were selected in three waves. For the first and second waves, four cases were chosen randomly from the list of OER projects produced. Two cases were selected from the list of OER projects that use the co-production model and two from the list of projects that use the producer-consumer model. Eisenhardt (1989) suggests using theoretical sampling when selecting cases for case study research which implies that cases may be chosen to replicate previous cases or extend emergent theory. For this study, previous research did not provide a reference to select the cases using theoretical sampling as suggested by Eisenhardt (1989). When data from the first two waves was collected and preliminary results emerged, a third wave of four projects was chosen using theoretical 
sampling. The last four projects selected had the potential to extend and refine the initial results (Eisenhardt, 1989).

\subsubsection{Collect data}

\section{Motives for establishing OER projects}

Information on the motives of institutions for establishing OER projects was drawn from secondary sources. The websites of the OER projects in the sample in the sections about, project's history, frequently asked questions and help were examined searching for information about motives for establishing the OER projects. Some OER projects have annual evaluation reports that were examined for information. In addition, information about the motives for establishing the projects was found in published case studies (OECD, 2007).

Differences of governance used by OER projects that utilize the co-production and the producer-consumer model for content development

Five dimensions of governance of OER projects were chosen from the literature review on governance of OSS and OER. Table 19 identifies the governance dimensions selected to identify the differences in the governance used by OER projects that utilize the coproduction and the producer-consumer model for content development, and the sources used to obtain data about these dimensions. 


\begin{tabular}{|l|l|l|}
\hline \multicolumn{2}{|c|}{ Table 19 } & \multicolumn{1}{c|}{ Governance dimensions } \\
\hline No. & \multicolumn{1}{|c|}{ Governance dimension } & \multicolumn{1}{c|}{ Sources of information } \\
\hline 1 & Organizational structure & Project website: about section, FAQ \\
\hline 2 & $\begin{array}{l}\text { Participation of volunteer } \\
\text { contributors }\end{array}$ & $\begin{array}{l}\text { Project website: about section, white papers, } \\
\text { FAQ }\end{array}$ \\
\hline 3 & Partnerships & Project website: organization, about, sponsors \\
\hline 4 & Intellectual property license & Project website: help, FAQ \\
\hline 5 & Core mission & Project website: about section, help, FAQ \\
\hline
\end{tabular}

How OER projects protect their content

Table 14 presents a list of tactics that OSS projects use to protect their work (O'Mahony, 2003). Table 14 provides a guide to data collection. The following steps were undertaken to collect the data:

\section{$\underline{\text { Step } 1}$}

Initial codes were generated for each of the tactics in Table 14.

$\underline{\text { Step } 2}$

Project's website sections such as: i) organization, ii) frequently asked questions and iii) about, were screened for codes. Press releases and case studies of individual OER projects from the OECD contained detailed descriptions of some OER projects, including their use of licenses and measures to protect their content.

\section{$\underline{\text { Step } 3}$}

Responses from interviews to OER and OSS experts related to IP protection were another source of data on the tactics used by OER projects to protect their content. 


\section{Uniqueness of OER}

Data on uniqueness of OER in terms of: i) motives for establishing the projects, ii) governance of the project and content production and, iii) IP protection were collected using the responses from the questionnaire sent to OER and OSS experts.

A total of 29 experts were contacted and 14 of them (49\%) agreed to participate in the survey.

Initially, 20 experts were contacted through email to participate in the study. The initial participants recommended 9 more people for the study that were later contacted by email.

Out of the 14 experts that agreed to participate in the study, 6 of them were interviewed by phone and 8 of them replied by email.

\subsubsection{Analyze data}

Motives of institutions to establish OER projects

The motives for establishing OER projects were organized into a table. The information was drawn from the secondary sources identified in section 3.3.6. Then, responses were coded to classify the data into different categories.

An initial list of codes was produced using information from the literature review on the motivations of institutions to participate in OER projects, presented in Table 6 . These codes were expanded and refined throughout the study by inductively adding, eliminating, clustering and sorting the codes (Glaser, 1998; Miles \& Huberman, 1994) each time data on a new case was added. 
Differences in governance used by OER projects that utilize the co-production and the producer-consumer model for content development

Data on the five governance dimensions identified in section 3.3.2 were collected for OER projects that utilize the co-production and the producer-consumer model for content development. Differences between the two models for content development were discussed.

How OER projects protect their content

To categorize the methods OER projects use to protect their content, the following steps were carried out:

$\underline{\text { Step } 1}$

An initial list from the tactics employed by OSS projects to protect their work was organized into a table and codes were extracted for each tactic. These codes helped guide the data collection.

\section{Step 2}

Data collected from primary sources (interviews to OER and OSS experts) and secondary sources (e.g., OER projects' websites, case studies, OER project's reports) were used to gather the tactics used by OER projects to protect their content.

\section{Step 3}

Tactics from OSS to protect their work were compared with the data collected from interviews and secondary sources. This comparison helped to create a list of the tactics 
used by OER projects to protect their content. Data that did not fit with any tactic used by OSS projects were set apart and listed as a new tactic.

\section{Uniqueness of OER}

Uniqueness of OER was analyzed for each of the three aspects in this study: i) motives for establishing the projects, ii) governance of the project and content production and, iii) IP protection.

From the responses to the questionnaires and transcriptions of the interviews, statements related to the uniqueness of OER were extracted and simplified. These statements were initially organized into three categories, according to the consideration of the participants: i) related to motives for establishing the projects, ii) related to the governance of the projects and content production and iii) related to IP protection.

Some participants contributed additional statements about the uniqueness of OER that did not fall in any of the three categories suggested by the researcher. These statements were also extracted and simplified. A new category called "others" was added to the initial three. 


\section{WRITE UPS OF OER PROJECTS IN THE SAMPLE}

The sample used in this study included 12 institutions and non profit organizations that established OER projects between 2001 and 2008.

Table 20 identifies the OER projects included in the sample. For each project Table 20 provides: i) wave in which it was included in the analysis, ii) whether the OER project is uses the co-production or producer-consumer model for content development, iii) name of the institution that hosts the project and, iv) project's website. 


\begin{tabular}{|c|c|c|c|c|c|}
\hline \multicolumn{3}{|c|}{ Table 20} & \multicolumn{3}{|c|}{ OER projects included in the sample } \\
\hline No & Project & Wave & Type & $\begin{array}{c}\text { Institution that hosts } \\
\text { the project }\end{array}$ & Project's website \\
\hline 1 & MIT OCW & \multirow{4}{*}{ I } & \multirow{2}{*}{$\mathrm{P}-\mathrm{C}$} & $\begin{array}{l}\text { Massachusetts Institute } \\
\text { of Technology }\end{array}$ & ocw.mit.edu \\
\hline 2 & Tufts & & & Tufts University & ocw.tufts.edu \\
\hline 3 & Connexions & & \multirow[b]{2}{*}{$\mathrm{C}$} & Rice University & cnx.org \\
\hline 4 & WikiEducator & & & $\begin{array}{l}\text { Commonwealth of } \\
\text { learning }\end{array}$ & wikieducator.org \\
\hline 5 & $\begin{array}{c}\text { Open } \\
\text { Learning } \\
\text { Initiative } \\
\text { (OLI) }\end{array}$ & \multirow{4}{*}{ II } & \multirow[t]{2}{*}{ P-C } & $\begin{array}{l}\text { Carnegie Mellon } \\
\text { University }\end{array}$ & cmu.edu/oli \\
\hline 6 & TU Delft & & & $\begin{array}{l}\text { Delft University of } \\
\text { Technology }\end{array}$ & ocw.tudelft.nl/home \\
\hline 7 & LeMill & & \multirow{2}{*}{$\mathrm{C}$} & $\begin{array}{l}\text { University of Art and } \\
\text { Design Helsinki }\end{array}$ & lemill.net \\
\hline 8 & Curriki & & & $\begin{array}{l}\text { Global education and } \\
\text { learning community }\end{array}$ & curriki.org \\
\hline 9 & Sofia & \multirow{4}{*}{ III } & \multirow[b]{2}{*}{$\mathrm{P}-\mathrm{C}$} & Foothill College & sofia.fhda.edu \\
\hline 10 & $\begin{array}{c}\text { National } \\
\text { Repository of } \\
\text { Online } \\
\text { Courses } \\
\text { (NROC) }\end{array}$ & & & $\begin{array}{l}\text { Monterrey Institute for } \\
\text { Technology and } \\
\text { Education }\end{array}$ & $\begin{array}{l}\text { montereyinstitute.org } \\
\text { nroc }\end{array}$ \\
\hline 11 & OpenLearn & & \multirow{2}{*}{$\mathrm{C}$} & Open University & openlearn.open.ac.uk \\
\hline 12 & Wikiversity & & & Wikimedia Foundation & en.wikiversity.org/ \\
\hline
\end{tabular}

Note: "P-C", producer-consumer model; “C", co-production model

\subsection{MIT OCW}

MIT OCW is a free publication of course materials used at MIT. The project started on 2002 with a pilot version of 50 courses, including Spanish and Portuguese translations. In 2003, the official launch was made with 500 courses and Chinese translations added. In 2007 MIT announced that virtually all MIT courses, 1,800 in total were published on the MIT OCW. 
The courses offered include at least a syllabus, course calendar, and lecture notes. Most courses also have one or more additional categories of material such as assignments, exams, problem/solution sets, labs, projects, hypertext books, simulations, demonstration/learning tools, tutorials, and video lectures.

The project was envisioned to be a strategy that would allow MIT to position itself in the distance/e-learning environment. MIT OCW's goals are to provide free access to virtually all MIT course materials for educators, students, and individual learners around the world and, to extend the reach and impact of MIT OCW and the OCW concept.

MIT OCW is not a distance-learning, credit bearing, or degree-granting initiative. Faculty participation is voluntary and the content is offered under the Creative Commons, Attribution - Noncommercial - Share Alike license. This license does not allow commercial use of the content unless it is authorized by the authors.

MIT OCW receives support from the William and Flora Hewlett Foundation and the Andrew W. Mellon Foundation, as well as from Massachusetts Institute of Technology, and the MIT Faculty.

MIT OCW is member of the OCW Consortium ${ }^{14}$, which is a collaboration of more than 100 higher education institutions and associated organizations from around the world creating a broad and deep body of open educational content using a shared model.

${ }^{14}$ http://www.ocwconsortium.org 


\subsection{Tufts}

Tufts University OCW is a free, online publication of high quality educational material from a number of Tufts University courses available for use by self learners, students, and faculty around the world. Member of the OCW Consortium, the Tufts OCW was launched in 2005 and its goals include promoting an international perspective, and fostering Tufts' tradition of service to its local, national and international communities. The project relies extensively on the technical resources available in the Tufts University Sciences Knowledgebase (TUSK) that was developed by the School of Medicine. The project is supported by in-kind contributions of faculty and staff time and received a grant from the Hewlett Foundation to support the staff needed for content development and for tool creation. Faculty participation is voluntary.

Tufts OCW currently offers 42 courses and 7 information websites to support the learning efforts of individuals around the world. These materials are available under the terms of the Creative Commons, Attribution - Noncommercial -Share Alike, Tufts Open Courseware License 1.0

The courses presented in the OCW do not contain the full content of the course as taught at Tufts. The included content is based on material the Tufts faculty and instructors choose to include, as well as factors such as content preparation, software compatibility, and intellectual property and copyright restrictions. Tufts OCW does not accept contributions from external users as its aim is to reflect the course materials being taught at Tufts. 


\subsection{Connexions}

Connexions is a non profit start up launched at Rice University in 1999. Connexions is an environment for collaboratively developing, freely sharing, and rapidly publishing scholarly content on the Web. The content in Connexions is organized into modules that are connected into a larger collection of courses and anyone can contribute to the Connexions repository and modify and redistribute modules.

As of April 2008 there were available 5294 reusable modules integrated into 322 collections. Connexions' major supporter is the William and Flora Hewlett Foundation.

Connexions aims to reinvent how we write, edit, publish, and use textbooks and other learning materials. It is a global repository of educational content in which users can: i) create educational materials and contribute them to the repository, ii) copy the material and customize it, iii) mix the material together into new books and courses, and iv) create finished products like e-learning web courses, compact disks, and even printed books.

All the materials created using the Connexions platform should be licensed under the Creative Commons, Attribution license. Commercial use of the content on Connexions is allowed.

The Connexions project team maintains the content commons as a whole. Individual courses and modules are maintained by their instructors and authors.

\subsection{WikiEducator}

WikiEducator is an OER project supported by the Commonwealth of Learning. It was launched on May, 2006. 
WikiEducator aims to build a sustainable global community dedicated to the design, development and delivery of free content for learning in realisation of a free version of the education curriculum by 2015 .

WikiEducator was conceived as a website for educators to develop free educational content that anyone can use, modify and distribute. As the WikiEducator community has evolved, distinct uses of the site have emerged: i) free content development - these are the actual content pages, ii) planning pages for projects developing free educational content, iii) community network nodes which facilitate a range of free content activities and, iv) research projects hosted on WikiEducator.

Any person or institution can develop and/or use the educational materials in WikiEducator. Several roles exist to contribute to WikiEducator based on the experience and interests of the potential contributors.

The project has a community governance model which is coordinated by the Interim International Advisory Board.

All the content created in WikiEducator uses the Creative Commons, Attribution, Share Alike or Creative Commons, Attribution.

WikiEducator recorded 15,147 visits to its website on 7 May 2008.

\subsection{OLI}

Open Learning Initiative (OLI) is an OER project at Carnegie Mellon University that began in 2002 with a grant from the William and Flora Hewlett Foundation. 
OLI creates web-based courses that are designed so that students can learn effectively without an instructor. In addition, the courses are often used by instructors to support and complement face-to-face classroom instruction. OLI supports evaluation efforts to investigate OLI courses' effectiveness in both of these instructional modes - stand-alone and hybrid.

OLI courses are developed by teams of learning scientists, faculty content experts, human computer interaction experts and software engineers. These experts work within the OLI project; users are not allowed to participate in the development process. There are currently eleven online courses and course materials freely available that enact instruction for an entire course in an online format.

OLI also allows any instructor interested in developing courses within the OLI platform to register and obtain authorization to develop courses without cost. Once the instructor has developed his course within the OLI platform, he can give his students a code to access this course and make use of the statistics and tutor tools available to keep track of the student's performance. There is no charge for creating an OLI instructor account or for creating an OLI course. However, several of the OLI courses do charge a per-student maintenance fee.

One representative feature of the courses at OLI is the use of "cognitive tutors" and "mini-tutors" that give students feedback in the problem solving context. A cognitive tutor is a computerized learning environment whose design is based on cognitive principles and whose interaction with students is based on that of a (human) tutor - e.g., 
making comments when the student errs, answering questions about what to do next, and maintaining a low profile when the student is performing well.

All the content in the OLI is licensed under the Creative Commons, AttributionNoncommercial-Share Alike.

\subsection{TU Delft}

TU Delft is an OER project established by the Delft University of Technology in 2006. TU Delft OCW is intended as a publication of TU Delft course materials on the Web, not as an interactive experience with TU Delft faculty. Users are not allowed to participate in the content development process as the project aims to showcase the courses as they are taught at Delft University of Technology.

As of July, 2008 there were 17 courses available on TU Delft. Participation of TU Delft faculty in TU Delft OCW is completely voluntary.

TU Delft OCW is member of the OCW Consortium and was recently elected to participate in the board of directors.

Course materials are licensed under the terms of Creative Commons, AttributionNoncommercial-Share Alike 3.0 Netherlands.

\subsection{LeMill}

LeMill is an OER project established in 2006 and hosted by the Media Lab, University of Art and Design Helsinki. LeMill is a web community for finding, authoring and sharing learning resources. LeMill design and development is lead by the Learning Environment Research group at the Media Lab, University of Art and Design Helsinki. The software 
development team is international with partners from Finland, Estonia, Hungary and Norway.

There are two kinds of content in LeMill: media pieces and learning resources. A media piece can be a single image, short audio file, or short video clip. A media piece is something that can be used as part of a larger resource. Learning resource is the larger unit of content. A learning resource can be the complete lesson material used in a course.

Anyone can join LeMill and develop content. As of July, 2008 there were 2796 teachers and other learning content creators and 1397 reusable learning content resources, 292 descriptions of teaching and learning methods, and 453 descriptions of teaching and learning tools.

All resources in LeMill are licensed under the Creative Commons, AttributionShareAlike 2.5 License.

\subsection{Curriki}

Curriki is an OER project launched in 2004 by the Global Education and Learning Community (GELC), an online project started by Sun Microsystems to develop works for education in a collaborative effort.

The goals of the project are: i) to develop curriculum through community contributors, ii) to deliver the curriculum globally and, iii) to determine the impact by project and by individual. The initial focus is on $\mathrm{K}-12$ curricula in the areas of mathematics, science, technology, reading and language arts, and languages. 
Curriki provides an online repository where anyone, anywhere, students or teacher, can contribute to and/or access learning materials.

The default Curriki license is the Creative Commons, Attribution. This is the most permissive license in Curriki. If the authors want to restrain more their content (e.g. add non commercial or no derivatives to the terms of the license) they are offered a list of other Creative Commons licenses with these characteristics from where to choose.

\subsection{Sofia}

Sofia project was launched in 2004 by Foothill College's Learning Technology \& Innovations program. The William and Flora Hewlett Foundation awarded a grant to the Foothill - De Anza Community College District to lead the establishment of an open courseware initiative for community colleges.

Sofia aims to support and advance education by making high-quality content freely available on the Web for learners and faculty across the nation and the world. The goal of Sofia is to publish community college-level course content and make it freely accessible on the web to support teaching and learning.

Sofia accepts contributions annually. Participation is voluntary and is open to faculty from community colleges and four-year universities. The project has established eligibility criteria for contributions, which includes the availability of the content online and the adoption of a Creative Commons license. Each author selects the Creative Commons license under which to license his course materials and places a link at the bottom of each page listing rights for modification and distribution of the available course materials. Quality materials are identified and selected from the submissions 
through a review process conducted by peer reviewers. Cash awards of $\$ 1,000$ are given to individuals whose content is selected.

As of April 2008, Sofia offered 8 courses available online for free.

\subsection{NROC}

The National Repository of Online Courses (NROC) is a non profit OER project established by the Monterey Institute for Technology and Education in 2004, with the economic support of the William and Flora Hewlett Foundation. NROC facilitates collaboration among a community of content developers to serve students and teachers worldwide.

Courses in the NROC library are contributed by developers from leading academic institutions across the United States that are members of the NROC network. All courses are assessed by a team of experts within NROC to ensure they meet standards of scholarship, instructional value, and presentational impact.

NROC supports free and open access for individual users by mixing institutional membership fees for educational and non profit organizations, licenses for commercial ventures and service fees for online course evaluations (Rominger \& Lopez, 2007). NROC is composed of two environments: the NROC Network and HippoCampus.

The NROC Network is an online, membership community for Higher Education and High School Educational Organizations. An annual fee ranging from $\$ 3,000$ to $\$ 100,000$ is charged to its members and provides them with a custom content (learning object) repository, faculty and staff with webinars, white papers, iPod downloadable versions of 
NROC content, participation in content development projects, and campus ownership of collaboratively developed content.

Members of the NROC Network can locally mix, mash, revise, and use NROC learning objects for online courses, hybrid and classroom teaching (Rominger \& Lopez, 2007).

HippoCampus is a free, public website for high school and lower-division college Students that offers NROC content indexed to popular textbooks. HippoCampus can be customized by instructors to meet the learning needs of their students. The content at HippoCampus is for personal use only. Commercial use of this content should be authorized by the NROC.

As of 2007, NROC has developed 26 courses in six disciplines. The courses are being used in at least eight different learning management systems and course repositories. With

\subsection{OpenLearn}

OpenLearn started in 2005 with a grant from the William and Flora Hewlett Foundation for GBP $£ 5.65$ million (US $\$ 9.9$ million) over two years. The project was established by the Open University located in the United Kingdom. Website development began in May 2006 and the site was launched in October 2006. The project is currently funded until 2008.

A difference for the Open University compared to many other participants in the movement is that it is a distance learning organization. 
The project consists of two environments: the LearningSpace and the LabSpace. The LearningSpace showcases the Open University learning materials created by faculty members. The LabSpace is the part of OpenLearn which is a community-led environment that fosters the concept of sharing and reusing educational resources. It is intended for educational and other professional practitioners and more adventurous learners.

The content in both environments is organized into units and these units are classified into introductory, intermediate, advanced or masters. The level indicates the amount of previous educational experience expected to enable users to study the unit without difficulty.

As of July, 2008 there were 451 units of content in the LearningSpace and 625 units of content in the LabSpace. Units vary greatly in terms of the amount of content, which is measured in terms of the number of hours required to cover the content in the unit.

It is not possible to gain any qualifications through OpenLearn and there are no formal educational qualifications required to use OpenLearn. OpenLearn materials are being translated into a number of languages, including Chinese, Spanish and Portuguese.

The Open University owns and retains copyright in its course materials. However, extracts from other sources are used under license.

OpenLearn grant users the right to make use of the materials as they are or in modified form. Materials can be translated, modified, printed, networked, reformatted or changed in any way providing that the terms of the following licences are met: unit materials in 
which OpenLearn owns copyright are licensed to use under the Creative Commons, Attribution-Noncommercial-Share Alike.

Unit materials in which OpenLearn does not own copyright, but which have been licensed for use from other rights holders, are identified in the acknowledgements attached to each unit of content. These extracts may be used freely as part of the unit in which they appear but OpenLearn is unable to grant the right to modify them or to use them as stand-alone items. The surrounding OpenLearn content may be modified, however, and the extract retained for use within the modified version.

\subsection{Wikiversity}

Wikiversity is an OER project established by the Wikimedia Foundation in 2006. The project first started developing on Wikibooks. The Wikibooks' Wikiversity section was proposed for deletion from Wikibooks in August 2005 and soon after that, there was a proposal to make Wikiversity an independent WikiMedia project. The approval was granted on 2006 and Wikiversity became independent.

Wkiversity is said to be different from Wikipedia in that the focus is on building learning communities that can use the wiki editing process itself as a way of learning.

Wikiversity is described as a site for the creation and use of free learning materials and activities. The mission of Wikiversity is to empower people to achieve their educational goals using resources produced by the free culture movement. The goals are to: i) create and host a range of free-content, multilingual learning materials/resources, for all age groups in all languages, ii) host scholarly/learning projects and communities that support these materials and, iii) complement and develop existing Wikimedia projects, such as 
Wikipedia. Wikiversity resources include teaching aids, lesson plans, curricula, links to off-site resources, course notes, example and problem sets, computer simulations, reading lists, and other as devised by participants. There are currently 8,296 learning resources available in the Wikiversity repository.

All the materials in Wikiversity are licensed under the GNU Free Documentation License (GFDL) is a copyleft license for free documentation, designed by the Free Software Foundation (FSF). This license gives readers the rights to copy, redistribute and modify a work and requires all copies and derivatives to be available under the same license. The GFDL requires the ability to "copy and distribute the document in any medium, either commercially or non-commercially" and therefore is incompatible with material that excludes commercial re-use. Material that restricts commercial re-use is incompatible with the license and cannot be incorporated into the work. 


\section{RESULTS}

This chapter is organized into four sections. Section 5.1 presents the motives of academic institutions and non profit organizations for establishing OER projects. Section 5.2 presents the differences between the governance used by OER projects that utilize the co-production and the production-consumer model. Section 5.3 presents the ways OER projects protect their content. Finally, section 5.4 presents the uniqueness of OER relative to OSS in terms of: i) motives for establishing the projects, ii) governance and, iii) IP protection and, iv) others.

\subsection{Motives for establishing OER projects}

Data from 12 OER projects were used to establish the motives to establish OER projects. Appendix D provides the codes and phrases used to organize the motives into categories. These categories are based on the raw data in Appendix C.

Table 21 identifies the motives and the number of cases that mentioned the motive for establishing OER projects. The motives for establishing OER projects are ordered by the number of cases that support each motive. 


\begin{tabular}{|l|c|}
\hline \multicolumn{2}{|c|}{ Table 21 Motives for establishing OER projects } \\
\hline \multicolumn{1}{|c|}{ Motive } & $\begin{array}{c}\text { Number of } \\
\text { cases }\end{array}$ \\
\hline $\begin{array}{l}\text { Increase access and free exchange of educational content } \\
\text { worldwide }\end{array}$ & 12 \\
\hline $\begin{array}{l}\text { Stimulate innovation around content development and online } \\
\text { instruction }\end{array}$ & 3 \\
\hline $\begin{array}{l}\text { Promote collaboration among faculty and/or content } \\
\text { developers }\end{array}$ & 2 \\
\hline Interact with a global community & 2 \\
\hline Enhance the quality of teaching & 2 \\
\hline Counter privatization of knowledge & 1 \\
\hline Showcase their courses to potential students & 1 \\
\hline Help to set standards for online content & 1 \\
\hline Increase the pool of online learning materials & 1 \\
\hline Support the OER movement & \\
\hline
\end{tabular}

The two main motives for academic institutions and non profit organizations for establishing OER projects are:

1. Increase access to education worldwide

2. Stimulate innovation around content development and online instruction

\subsection{Differences between the governance used by OER projects that utilize the co- production and the producer-consumer models for content development}

Appendix E presents the information used to collect the data on the five governance dimensions identified in section 3.3.2. After this data were collected, the researcher applied the criteria identified in Table 18 to determine the differences between the coproduction and producer-consumer models for content development.

The decision on how to best organize the data on the projects that use the co-production and the producer-consumer model was made by the researcher at the data collection step. 
Table 22 and Table 23 present the data on the governance dimensions according to the criteria identified in Table 18 for OER projects that use the co-production and the producer-consumer models for content development.

Table 22 Data on governance dimensions of OER projects that use the coproduction model

\begin{tabular}{|l|c|c|c|c|c|}
\hline $\begin{array}{c}\text { Dimen- } \\
\text { sion } \\
\text { OER }\end{array}$ & $\begin{array}{c}\text { Organiza- } \\
\text { tional } \\
\text { structure }\end{array}$ & $\begin{array}{c}\text { Participation } \\
\text { of volunteer } \\
\text { contributors }\end{array}$ & $\begin{array}{c}\text { Number of } \\
\text { partner } \\
\text { ships }\end{array}$ & $\begin{array}{c}\text { Intellectual } \\
\text { property } \\
\text { license }\end{array}$ & $\begin{array}{c}\text { Core } \\
\text { mission }\end{array}$ \\
\hline Connexions & Contributors & Unrestricted & 7 & $\begin{array}{c}\text { Non } \\
\text { restrictive }\end{array}$ & General \\
\hline $\begin{array}{l}\text { Wiki } \\
\text { Educator }\end{array}$ & Contributors & Unrestricted & 5 & $\begin{array}{c}\text { Partially } \\
\text { restrictive }\end{array}$ & Specialized \\
\hline LeMill & Contributors & Unrestricted & 6 & $\begin{array}{c}\text { Partially } \\
\text { restrictive }\end{array}$ & - \\
\hline Curriki & Contributors & Unrestricted & 31 & $\begin{array}{c}\text { Non } \\
\text { restrictive }\end{array}$ & General \\
\hline OpenLearn & $\begin{array}{c}\text { Contributors } \\
\text { and } \\
\text { staff }\end{array}$ & $\begin{array}{c}\text { Restricted and } \\
\text { unrestricted }\end{array}$ & 1 & Restrictive & Specialized \\
\hline Wikiversity & Contributors & Unrestricted & - & $\begin{array}{c}\text { Partially } \\
\text { restrictive }\end{array}$ & General \\
\hline
\end{tabular}




\begin{tabular}{|l|c|c|c|c|c|}
\hline \multicolumn{5}{|c|}{ Table 23 } & \multicolumn{5}{c|}{$\begin{array}{c}\text { Data on governance dimensions of OER projects that use the } \\
\text { producer-consumer model }\end{array}$} \\
\begin{tabular}{|l|c|c|c|c|} 
Dimen- \\
OER \\
sroject
\end{tabular} & $\begin{array}{c}\text { Organiza- } \\
\text { tional } \\
\text { structure }\end{array}$ & $\begin{array}{c}\text { Participation } \\
\text { of volunteer } \\
\text { contributors }\end{array}$ & $\begin{array}{c}\text { Number of } \\
\text { partner } \\
\text { ships }\end{array}$ & $\begin{array}{c}\text { Intellectual } \\
\text { property } \\
\text { license }\end{array}$ & $\begin{array}{c}\text { Core } \\
\text { mission }\end{array}$ \\
\hline MIT OCW & Staff & Restricted & 7 & Restrictive & General \\
\hline Tufts & Staff & Restricted & 7 & Restrictive & General \\
\hline OLI & - & Restricted & 1 & Restrictive & Specialized \\
\hline Tu Delft & - & Restricted & 1 & Restrictive & General \\
\hline Sofia & Staff & $\begin{array}{c}\text { Partially } \\
\text { restricted }\end{array}$ & 1 & Restrictive & General \\
\hline NROC & Staff & $\begin{array}{c}\text { Partially } \\
\text { restricted }\end{array}$ & 1 & Restrictive & General \\
\hline
\end{tabular}

Table 22 and Table 23 show that there are differences in terms of three of the five governance dimensions studied: i) organizational structure and ii) volunteer contributors and iii) intellectual property licenses. Table 24 presents a summary of the results for this three dimensions.

Table 24 Dimensions that can be used to establish differences between OER projects that use the co-production and the producer consumer models

\begin{tabular}{|l|c|c|}
\hline $\begin{array}{r}\text { Development } \\
\text { model }\end{array}$ & Co-production & Producer-consumer \\
\hline Organizational structure & Contributors & Staff \\
\hline $\begin{array}{l}\text { Participation of volunteer } \\
\text { contributors }\end{array}$ & Unrestricted & $\begin{array}{c}\text { Partially restricted } \\
\text { Restricted }\end{array}$ \\
\hline $\begin{array}{l}\text { Intellectual property } \\
\text { license }\end{array}$ & $\begin{array}{c}\text { Non restrictive } \\
\text { Partially restrictive }\end{array}$ & Restrictive \\
\hline
\end{tabular}

In addition, the results show that for the other two governance dimensions: i) number of partnerships and ii) core mission, the data varied across cases from the same group (coproduction or producer-consumer). Therefore, no differences between OER projects that 
use the co-production and the production-consumer models were established in terms of these two dimensions.

\section{$\underline{\text { Organizational structure }}$}

Table 22 shows that for the six OER projects that use the co-production model, contributors were in charge of publishing the content.

Table 23 shows that four of the six OER projects that use the producer-consumer model utilize staff from the institutions to publish the content. Data were not found on the organizational structure of the remaining two projects in Table 23.

Table 22 shows that the project OpenLearn, also use staff to publish the content. This is because OpenLearn has two environments for content development. One of them has the characteristics of the producer-consumer model (content is produced solely by the institution) and the other one was created to attract volunteer contributors and has the characteristics of the co-production model (users are allowed to add or modify the content in the project's repository).

\section{$\underline{\text { Participation of volunteer contributors }}$}

Table 22 shows that for the six OER projects studied that use the co-production model have no restrictions for volunteer contributors to participate in the content development process.

Table 23 shows that four of the six OER projects that use the producer-consumer model restrict the participation of volunteer contributor. The two remaining projects, restrict 
participation partially, meaning that they allow participation of volunteer contributors that meet their selection criteria.

Intellectual property licenses

Table 22 shows that OER projects that use the co-production model utilize licenses that are non restrictive, partially restrictive and restrictive whereas projects that use the producer-consumer model only utilize restrictive licenses that do not allow commercial use of their content as showed in Table 23.

\subsection{Content protection}

\subsubsection{Results from secondary sources}

Table 25 presents the three tactics for content protection identified from information on the projects' websites. Table 25 is organized by tactic and OER project in the sample. 


\begin{tabular}{|c|c|c|c|c|}
\hline \multirow[t]{3}{*}{ Table 25} & \multicolumn{4}{|c|}{$\begin{array}{l}\text { Tactics OER projects use to protect their content collected from } \\
\text { secondary sources of information }\end{array}$} \\
\hline & \multicolumn{4}{|c|}{ Tactics } \\
\hline & $\begin{array}{l}\text { Licenses that } \\
\text { restrict } \\
\text { proprietary } \\
\text { appropriation }\end{array}$ & $\begin{array}{l}\text { Licenses that } \\
\text { restrict } \\
\text { commercial use }\end{array}$ & $\underset{\text { logos }}{\text { Trademarks and }}$ & Total \\
\hline MIT OCW & $\mathrm{S}$ & $\mathrm{S}$ & $S$ & 3 \\
\hline Tufts & $S$ & $S$ & - & 2 \\
\hline Connexions & - & - & - & 0 \\
\hline $\begin{array}{l}\text { Wiki } \\
\text { Educator }\end{array}$ & S & - & - & 1 \\
\hline OLI & $S$ & $S$ & - & 2 \\
\hline TU Delft & $\mathrm{S}$ & $S$ & - & 2 \\
\hline LeMill & $\mathrm{S}$ & - & - & 1 \\
\hline Curriki & - & - & - & 0 \\
\hline Sofia & - & $S$ & - & 1 \\
\hline NROC & $S$ & $S$ & $\mathrm{~S}$ & 3 \\
\hline OpenLearn & $S$ & $S$ & - & 2 \\
\hline Wikiversity & $\mathrm{S}$ & - & - & 1 \\
\hline Total & 9 & 7 & 2 & 18 \\
\hline
\end{tabular}

Note: S: supported by secondary sources; "“-" not supported.

\section{Licenses that restrict proprietary appropriation}

Nine of the OER projects studied use licenses that restrict proprietary appropriation.

Eight of them use the clause of the Creative Commons Share Alike license and one of them (Sofia) uses copyright for this end. This clause states that authors let people create remixes and derivative works based on their work, as long as they only distribute them under the same Creative Commons license that the original work was published under. 


\section{Licenses that restrict commercial use}

Seven of the projects studied restrict commercial use of their content. They use the Creative Commons, Noncommercial license in which people can copy, distribute, display, perform, and remix the work for non commercial purposes only (Creative Commons website, 2008).

\section{Trademarks and logos}

Two of the projects studied (MIT OCW and TU Delft) used trademark to protect distinct brands or logos of the projects. They own the trademark over the brands and logos of the OER project.

\subsubsection{Results from primary sources}

Three tactics for content protection were identified from interviews of OER and OSS experts: i) licenses that restrict commercial use, ii) standards of academic practice and iii) policies controlling the use of the institution's name.

The use of licenses that restrict commercial use was confirmed by primary sources of data as well as from secondary sources of data. Two new tactics used by OER projects to protect their content were determined through interviews to OER and OSS experts:

\section{$\underline{\text { Standards of academic practice }}$}

Standards of academic practice refer to citation of sources, originality and prohibitions against plagiarism. These are used by OER projects to protect their content. 
Policies controlling the use of the institutional name

Policies controlling the use of institutional name are used to prevent any person, company or academic institution from implying that the content that they use is endorsed by the academic institution that hosts an OER project.

\subsection{Uniqueness of OER}

Table 26 presents the profile of the 14 questionnaire respondents. The questionnaire asked about the uniqueness of OER when compared to OSS in terms of three aspects: i) motivations for establishing the projects, ii) governance and, iii) IP protection.

\begin{tabular}{|l|c|}
\hline \multicolumn{1}{|c|}{ Table 26 Profile of the questionnaire respondents } \\
\hline \multicolumn{1}{|c|}{ Position } & $\begin{array}{c}\text { Number of } \\
\text { respondents }\end{array}$ \\
\hline $\begin{array}{l}\text { Directors of educational and technology } \\
\text { departments or institutes at academic } \\
\text { institutions }\end{array}$ & 5 \\
\hline $\begin{array}{l}\text { Executive/external relations director of an OER } \\
\text { project at an academic institution }\end{array}$ & 4 \\
\hline Founder of companies around OER & 2 \\
\hline Researchers & 1 \\
\hline $\begin{array}{l}\text { Director of OER project at a non profit } \\
\text { organization }\end{array}$ & 14 \\
\hline Total & 2 \\
\hline
\end{tabular}

The majority of the participants $(70 \%)$ hold directive positions either at educational/technology departments in academic institutions or at OER projects.

The responses from the participants were organized into 17 unique responses organized as follows: i) three responses related to motives, ii) five responses related to governance, 
iii) three responses related to IP protection and, iv) six responses that did not fall on any of the three previous categories.

\subsubsection{Motives}

Three responses from the participants were related to uniqueness of OER in terms of motivations:

1. OER is usually developed for secondary use after the publication of materials rather than something designed to meet a primary need. OSS projects begin with a developer scratching his/her own itch.

2. OER contributors are motivated by a combination of desire to help those who can not afford commercial educational resources and offer alternatives to commercial publishers. In OSS more important motivations are to open up code to improve it and fix bugs and the desire to build reputation capital.

3. OSS was aided by businesses who did not want to depend on proprietary software companies. Academic institutions do not have the need to stop relying on commercial textbooks.

\subsubsection{Governance}

Five responses from the participants were related to uniqueness of OER in terms of governance:

1. The widely used OSS collaborative approach for code development is hard to duplicate for OER. When developing educational materials it is hard to get big groups to agree on common solutions. Educational circumstances are highly localized and depend on the cultures and academic systems in which they exist, the technologies available and preferred, and the preparation and abilities of the 
students. As a consequence, there are very few OER that have been developed collaboratively.

2. OER crosses multiple administrative lines while OSS tends to stay within the IT environment of an organization or firm.

3. Origin of the respective movements is different. OER projects started more top down institutionally driven than bottom up as OSS projects. OSS began as a grassroots effort by a few pioneers (like Richard Stallman). OER originated with a more top down approach, backed by recognized academic institutions and world bodies such as UNESCO.

4. Some representative OSS projects have an undisputed leader who is usually the person who developed the initial code for the project or made another important contribution early in the project. OER projects do not have the same characteristic.

5. OSS code typically requires tighter control at some level as the dependencies among components are system critical. The same does not occur with OER.

\subsubsection{IP protection}

Three responses from the participants were related to uniqueness of OER in terms of IP protection:

1. OER movement has a strong anti-commercial streak that is reflected in some of the licenses used for open content. Some representative OER projects have adopted a license that does not allow commercial use of the content. Anti commercial licenses are largely alien to the OSS movement. 
2. The OER community is concerned with protecting the rights of authors to a greater extent than the OSS community. There is still a strong tendency to include the Noncommercial clause when licensing OER. The OSS community is more concerned with protecting their freedom to use, adapt, enhance and share the code.

3. The pervasive use of Creative Common licenses over the most common used General Public License (GPL) for OSS is something unique to OER.

\subsubsection{Others}

Six responses from the participants did not fall into any of the previous categories:

1. Massive amounts of money came into OSS from corporations and later in its development. As a consequence, the OSS movement developed its own principles of operation and ways of doing things, creating a sustainable ecosystem since the beginning. OER did not really take off until there was a massive injection of money by non profit funding sources like the William and Flora Hewlett Foundation.

2. It is much harder to determine an end point for an OER content than it is for OSS code. An end point for OSS code is when it runs correctly whereas the end point for OER is much more dependent on the situation in which is used.

3. More OER users appreciate more the fact that the educational materials are offered openly to everyone. OSS users, especially those with no technical background do not care as much about the openness of OSS code. What it matters to them is that the program performs correctly not that they can see and/or modify the source code of the program. 
4. The concept of access to the source code is not present in OER.

5. Ways to monetize from OSS are more palpable and mature than from OER. There is not the same opportunity for consulting and support as a revenue model in OER as in OSS.

6. The education focus is unique to the OER movement and differentiates it from OSS. OER is accessible across disciplines and has a pedagogical structure. OSS can be used for learning but is not the main intent. 


\section{DISCUSSION OF RESULTS}

This section uses the results in chapter 5 to answer the four research questions. The chapter is organized into four sections. Section 6.1 answers the first research question: what are the motives of academic institutions and non profit institutions for establishing OER projects? Section 6.2 answers the second research question: what are the differences between the governance used by OER projects that utilize the co-production and the producer-consumer model for content development? Section 6.3 answers the third research question: how do OER projects protect their content? Finally, section 6.4 answers the fourth research question: what is unique about OER when compared to OSS in terms of: i) motives for establishing the projects, ii) governance of the project and content production and, iii) IP protection?

\subsection{Motives for establishing OER projects}

Table 27 presents a comparison between the motives for establishing the projects that were identified in this study and the ones identified from the OER literature (Joyce, 2006; Hylén, 2006a; Baldi et al., 2002) and summarized in Table 6. 


\section{Table 27 Comparison between motives for establishing OER projects}

\begin{tabular}{|c|c|}
\hline Identified in this study & Identified in the literature \\
\hline $\begin{array}{l}\text { - Increase access and free exchange of } \\
\text { - } \text { Enhance quality of teaching } \\
\text { - } \text { Counter privatization of knowledge } \\
\text { - Showcase their courses to potential st } \\
\text { - Stimulate innovation }\end{array}$ & $\begin{array}{l}\text { icational content worldwide } \\
\text { ents }\end{array}$ \\
\hline $\begin{array}{l}\text { - Promote collaboration among faculty } \\
\text { and/or content developers } \\
\text { - Interact with a global community } \\
\text { - Help to set standards for online } \\
\text { content } \\
\text { Increase the pool of online learning } \\
\text { materials } \\
\text { Support the OER movement }\end{array}$ & $\begin{array}{l}\text { - Cost reduction } \\
\text { Experimenting with new business } \\
\text { models } \\
\text { Leverage taxpayer's money }\end{array}$ \\
\hline
\end{tabular}

Table 27 shows that the results of this research confirm five of the eight motives identified in the literature (Joyce, 2006; Hylén, 2006a; Baldi et al., 2002). In addition, it adds five new motives to the extant literature.

Bonaccorsi and Rossi (2004) divide the motivations of firms to participate in OSS projects into three groups: i) economic, ii) social and iii) technological. The motives of institutions for establishing OER projects found in this research suggest that institutions 
and non profit organizations are establishing OER projects for social reasons more than for economic or technological reasons.

Three of the motives identified in the OER literature (Joyce, 2006; Hylén, 2006a; Baldi et al., 2002): i) cost reduction and ii) experimenting with new business models and, iii) leverage taxpayer's money, were not identified as motives for establishing OER projects in this study.

Discourse analysis of OER projects (dos Santos, McAndrew \& Godwin, 2007) suggests that the argument of widening participation, social inclusion and the idea of creating a better world is dominant within OER projects. Less dominant but also present, is the argument of financial sustainability of OER projects, drawing on a business oriented perspective of the educational institutions. The discourse analysis of OER suggests that the motives for establishing the projects expressed in the project's websites might reflect the dominance of the arguments related to ethical reasons over the arguments related to financial sustainability.

\subsection{Differences in the governance used by OER projects that utilize the co- production and the producer-consumer models for content development}

Five governance dimensions were used to establish differences between OER projects that utilize the co-production and the producer-consumer model. Three of them were extracted from the OER literature: i) organizational structure, ii) participation of volunteer contributors and iii) number of partnerships. Two of them were extracted from the OSS literature: i) intellectual property licenses and ii) core mission. 
The data collected confirmed differences between the two models on two of the three OER governance dimensions used in this study: i) organizational structure and ii) participation of volunteer contributors.

\section{Organizational structure}

In terms of organizational structure, OER projects that use the producer-consumer model have staff in place to help authors publish their content, whereas projects that use the coproduction model have web interfaces designed to allow authors to publish the content themselves.

Keats (2003) identified that the organizational structure of OER projects that use the coproduction is more decentralized, meaning that the work of content publishing is more distributed among the authors. The results of this study confirm this statement.

\section{$\underline{\text { Participation of volunteer contributors }}$}

In terms of volunteer contributors, Table 22 shows that OER projects that use the producer-consumer model are either restrictive or partially restrictive with the participation volunteer contributors. Four of the six OER projects in Table 22 are restrictive and two are partially restrictive. The four OER projects that are restrictive are hosted by academic institutions. The most frequent reason cited for not allowing volunteer contributors is that their OER projects are meant to reflect what is taught at their academic institutions and they take full responsibility for it.

The remaining two OER projects that have partial restrictions for volunteer contributors are non profit organizations and are not directly affiliated to academic institutions. One 
of them is the OER project NROC, in which volunteer participation is allowed only from faculty at academic institutions that have paid a membership to become part of the NROC network. In the other OER project, Sofia, participation is open to faculty from community colleges and four-year universities only.

Table 23 shows that all the projects that use the co-production model were found to allow unrestricted participation from volunteer contributors. A particular case, the OER project OpenLearn, was found to be restrictive and unrestrictive. This is because OpenLearn has two environments for content development: one that restricts volunteers from participating and one that allows unrestricted participation of volunteer contributors.

Keats (2003) established that projects that use the co-production model welcome new development partners and that projects that use the producer-consumer model have a exclusive policy for new development partners. The results on Table 23 confirm that OER projects that use the producer-consumer model welcome new partners, however some of them have partial restrictions.

In addition, Table 23 shows that OER projects that use the co-production model do not impose any restrictions on new development partners or volunteer contributors. This is consistent with Keats (2003).

In terms of the third OER governance dimension, number of partnerships, the results did not confirm differences between the co-production and the producer-consumer model. 


\section{Partnerships}

The Organization for Economic Co-operation and Development (2007) states that OER projects that use the co-production model tend to have more partnerships than projects that use the producer-consumer model. The results presented in Table 22 and Table 23 did not confirm this statement. Four out of the six projects that use the producerconsumer model have low number of partnerships (less than five), whereas four out of six projects that use the co-production model have a high number of partnerships (five or more).

In terms of the OSS governance dimensions used: i) intellectual property license and ii) core mission, the results suggest that the intellectual property license dimension can be used to establish differences between the co-production and the producer-consumer model.

\section{$\underline{\text { Intellectual property license }}$}

The OER literature (Keats, 2003; Organization for Economic Co-operation and Development, 2007) does not establish differences in terms of their choices of licenses between projects that use the co-production and the producer-consumer model.

Table 22 shows that projects that use the co-production model tend to chose licenses that require only attribution to the authors (non restrictive) and derivative content to be under the same original license (partially restrictive) over licenses that do not allow commercial use (restrictive). Table 23 shows that projects that use the producer-consumer model tend to chose licenses that avoid commercial use of their content (restrictive). 


\section{$\underline{\text { Core mission }}$}

Results for the governance dimension core mission did not suggest differences between the co-production and the producer-consumer model.

The majority (72\%) of the 12 projects studied have a general mission, usually related to increase access and sharing of free resources education worldwide. Only three of the project studied were found to have specialized mission, often related to build curriculum and improve online learning.

\subsection{Content protection}

Two of the tactics identified in this study: i) restrict proprietary usage and ii) the use trademarks and logos, are consistent with the tactics used by OSS projects identified by O'Mahony (2003). The other five tactics identified by O'Mahony (2003) and presented in Table 14 were not present in OER projects.

All the OER projects in the sample were established by academic institutions or non profit organizations, therefore they did not need to create a legal entity to hold their intellectual property such as in the case of the OSS projects studied by O'Mahony (2003).

Another tactic adopted by OSS projects is the use formal and informal mechanisms to enforce compliance with their licenses (O’Mahony, 2003). Informal mechanisms include reports of the violations in community wide mailing lists and formal mechanisms include entities such as the Free Software Foundation, created primarily to enforce the GNU operating system GPL license. Data were not found to confirm the use similar mechanisms by OER projects to enforce license compliance. 


\subsection{Uniqueness of OER}

Table 16 presents ten aspects in which OER and OSS are different. These were identified in the literature. Three of these aspects were confirmed by the results of this research:

- Ways to profit from OER are not well understood yet

- Testing tools for OER are based on peer review not on software tools as in OSS

- OER are motivated more by social reasons that for economic or technological reasons

From the 17 unique responses presented in section 5.4 a list of six dimensions that can be used to distinguish OER and OSS was produced.

Table 28 provides the open source model. The top of Table 28 identifies the three aspects that are common to OER and OSS. In addition Table 28 presents six aspects that can be used to distinguish OER and OSS. 


\begin{tabular}{|c|c|c|}
\hline & Open source $n$ & \\
\hline & $\begin{array}{l}\text { Ope } \\
\text { - Provides access to kno } \\
\text { of copyright } \\
\text { - Knowledge is embodie } \\
\text { copied, modified and dis } \\
\text { - Peer recognition and so } \\
\text { reasons why individuals }\end{array}$ & $\begin{array}{l}\text { Irce } \\
\text { without the restrictions } \\
\text { irtual assets that can be } \\
\text { ted for free } \\
\text { notives are two main } \\
\text { ibute }\end{array}$ \\
\hline Aspect & OER & OSS \\
\hline $\begin{array}{l}\text { Testing and quality } \\
\text { assurance }\end{array}$ & Human based & Through software tools \\
\hline $\begin{array}{l}\text { Are business models well } \\
\text { understood? }\end{array}$ & No & Yes \\
\hline $\begin{array}{l}\text { Is component dependency } \\
\text { critical to the functioning } \\
\text { of the asset? }\end{array}$ & No & Yes \\
\hline $\begin{array}{l}\text { Main providers of } \\
\text { financial support for the } \\
\text { projects }\end{array}$ & $\begin{array}{c}\text { Foundations and academic } \\
\text { institutions }\end{array}$ & Companies \\
\hline Dominant license & Creative Commons & GPL \\
\hline $\begin{array}{l}\text { Is technology } \\
\text { advancement a main } \\
\text { reason for individuals to } \\
\text { contribute? }\end{array}$ & No & Yes \\
\hline
\end{tabular}




\section{CONCLUSIONS, LIMITATIONS AND FUTURE RESEARCH}

\subsection{Conclusions}

This research built on the literature on open source software (OSS) to identify three areas to analyze open educational resources (OER): i) motives for establishing the projects, ii) governance and, iii) intellectual property protection.

The objective of this research was to answer four research questions:

1. What are the motives of institutions for establishing OER projects?

2. What are the differences between the governance used by OER projects that utilize the co-production and the producer-consumer model for content development?

3. How do OER projects protect their content?

4. What is unique about OER when compared to OSS?

Data collected on 12 OER projects and questionnaires and interviews to OER and OSS experts were used to answer these four questions.

\subsubsection{Key findings}

- Academic institutions and non profit organizations are establishing OER projects for social reasons more than for economic or technological reasons.

- OER projects started more top-down institutionally driven than bottom-up as OSS projects. This top-down approach of OER projects forces institutions to think more about sustainability because of the high costs involved than OSS projects who are sustained by the efforts of volunteer contributors. 
- The governance dimension intellectual property licenses can be used to establish differences between OER projects that use the co-production and the producerconsumer model in addition to two existing dimensions: i) organizational structure and ii) participation of volunteer contributors.

- OER projects use at least five tactics to protect their content from which two are used by OSS projects as well: i) licenses that restrict proprietary appropriation, and ii) trademarks and logos.

- There are at least six dimensions that establish differences between OER and OSS.

\subsection{Limitations}

This study has three limitations. First, one of the main sources of information is secondary data from the projects websites. Eisenhardt (1989) recommends using multiple data collection methods to provide a strong validation of the results.

Second, the OER movement is in its early stages and most OER projects are relatively new, therefore the number of projects that can be studied is not large. In addition, there is no database with the names of all existing OER projects that can be used for research purposes.

Third, not all the OER projects studied have the same depth of information available in their websites. Therefore in some cases, the data required for this study were not available.

\subsection{Opportunities for future research}

This section identifies three opportunities for future research. First, researchers can analyze the motives for academic institutions and non profit organizations to establish 
OER projects using primary data sources, such as interviews with project managers to identify differences and similarities with the results identified in this study.

Second, researchers can analyze emerging OER projects from countries such as China, India and Vietnam to examine and compare the tactics they use to protect their content with the ones identified in this study.

Third, this research offers six aspects that are different between OER and OSS. These aspects can be used to develop hypothesis about differences between OER and OSS that can be validated through positive research. 


\section{REFERENCES}

Alam, R. 2006. Open Source Software projects, market offers and competitive advantage. Unpublished master dissertation. Carleton University, Ottawa.

Bailetti, T. 2007. TFN: Open Source and innovation. Open Source Business Resource. August issue. Available at http://www.osbr.ca/ojs/index.php/osbr/article/view/353/314 (retrieved January $25,2008)$

Bailetti, T. \& Hoddinott, P. 2007. Open Source assets. Open Source Business Resource. September issue. Available at http://www.osbr.ca/ojs/index.php/osbr/article/view/378/339 (retrieved January 25, 2008)

Baldi, S., Heier, H. \& Stanzick, F. 2002. OpenCourseWare vs. Open Source Software: a critical comparison. Proceedings of the 10th European Conference on Information Systems. Gdansk, Poland. Available at http://is2.lse.ac.uk/asp/aspecis/20020137.pdf (retrieved January 29, 2008)

Benkler, Y. 2005. Common wisdom: peer production of educational materials. Proceedings of the 17th Annual Instructional Technology Institute at Utah State University: Advancing the Effectiveness and Sustainability of Open Education. Utah, United States. Available at http://www.benkler.org/Common_Wisdom.pdf (retrieved February 23, 2008)

Bonaccorsi, A. \& Rossi, C. 2003. Why Open Source software can succeed. Research Policy, 32: 1243-1258.

Bonaccorsi, A. \& Rossi, C. 2004. Comparing motivations of individual programmers and firms to take part in the Open Source movement. From community to business. Free/ open source research community. Online papers. Available at http://opensource.mit.edu/papers/bnaccorsirossimotivationlong.pdf (retrieved January 30, 3008)

Carson, S. 2005. Program evaluation findings report. MIT OpenCourseWare. Available at http://ocw.mit.edu/ans7870/global/05_Prog_Eval_Report_Final.pdf (retrieved March 28, 2008)

Creative Commons, 2008. Frequently asked questions: terms of the Creative Commons license. Available at: http://wiki.creativecommons.org/FAQ\#How_do_I_register_my_copyright.3F (retrieved July 23, 2008) 
Christensen, C., Anthony, S. \& Roth, E. 2004. Seeing what's next: using the theories of innovation to predict industry change. Boston, Harvard Business School Press.

Christensen, C. \& Carlile, P. 2005. The Cycles of Theory Building in Management Research. Working paper no. 05-057. Harvard Business School. Available at http:/hbswk.hbs.edu/item/5422.html (retrieved June 19, 2007)

Comino, S., Manenti, F. \& Parisi, M. 2007. From planning to mature: on the success of open source projects. Research Policy. 36:1575-1586.

Dahlander, L. \& Magnusson, G. 2005. Relationships between open source software companies and communities: observations of Nordic firms. Research Policy, 34(4): 481-493.

de Laat, P. 2007. Governance of Open Source Software: state of the art. Journal Manage Governance, 11: 165-177

Dholakia, U., King, W. J. \& Baraniuk R. 2006. What makes an open education program sustainable? The case of Connexions. CERI - Closed expert meeting on Open Educational Resources: reports. Available at http://www.oecd.org/dataoecd/3/6/36781781.pdf (retrieved June 20, 2007)

dos Santos, A., McAndrew, P., Godwin, S. 2007. The discourses of OER: How flat is the world?. In proceedings of Open Education 2007: Localizing and learning. Began, $\boldsymbol{U T}$. pp 37-48

Downes, S. 2006. Models for sustainable Open Educational Resources. CERI - Closed expert meeting on Open Educational Resources: reports. Available at http://www.oecd.org/dataoecd/3/5/36781698.pdf (retrieved January 27, 2008)

Eisenhardt, K. 1989. Building theories from case study research. Academy of Management Review, 14(4): 532-550.

Feller J. \& Fitzgerald, B. 2000. A framework analysis of the Open Source Software development paradigm. Proceedings of the 21st Annual International Conference on Information Systems. Brisbane, Queensland, Australia, pp. 58-69. Available at http://www.csis.ul.ie/staff/bf/oss-icis00.pdf (retrieved January 19, 2008)

Feller, J. \& Fitzgerald, B. 2002. Understanding Open Source Software development. London, Boston: Addison-Wesley.

FOSS solutions for OER - summary report. 2007. International community of interest, Open Educational Resources, open content for higher education UNESCO-IIEP. Available at http://oerwiki.iiepunesco.org/index.php?title=FOSS_solutions_for_OER_-_summary_report (retrieved October 11, 2007) 
Gacek, C. \& Arief, B. 2004. The many meanings of Open Source. IEEE Software, 21(1): 34-40.

Geser, G. 2007. Open Educational Practices and Resources, OLCOS Roadmap 2012. Austria: Salzburg Research / EduMedia Group. Available at http://www.olcos.org/english/roadmap/download/ (retrieved January 25, 2008)

Glaser, B. 1998. Doing Grounded Theory: issues and discussions. Sociology Press.

Henry, G., Baraniuk, R. \& Kelty, C. 2003. The Connexions project: promoting open sharing of knowledge for education. Rice University digital repository. Available at http://rudr.rice.edu/handle/1911/19951 (retrieved February 22, 2008)

Hylén, J. 2006. Open Educational Resources: opportunities and challenges. CERI - Open Educational Resources: preliminary findings. Available at http://www.oecd.org/dataoecd/5/47/37351085.pdf (retrieved June 21, 2007)

Hylén, J. 2006a. Findings from an OECD study - Background note 2 Why are individuals and institutions using and producing OER? Available at http://www.unesco.org/iiep/virtualuniversity/forumsfiche.php?queryforumspages _id $=27$ (retrieved July 20, 2008)

Joyce, A. 2006. Internet discussion forum: Open Educational Resources findings from an OECD study. UNESCO-IIEP. Available at http://oerwiki.iiepunesco.org/images/e/ea/Oer_forum_report.pdf (retrieved January 27, 2008)

Keats, D. 2003. Collaborative development of open content: a process model to unlock the potential for African universities. First Monday, Peer-Reviewed Journal on the Internet, 8(2). Available at http://www.firstmonday.org/issues/issue8_2/keats/index.html (retrieved February $20,2008)$

Koenig, J. 2004. Seven open source business strategies for competitive advantage. IT Manager's Journal. Available at http://www.itmanagersjournal.com/articles/314 (retrieved January 19, 2008)

Kogut, B. \& Metiu, A. 2001. Open source software development and distributed innovation. Oxford Review of Economic Policy. 17(2): 248-264

Lattemann, C. \& Stieglitz, S. 2005. Framework for governance in Open Source Communities. Proceedings of the $38^{\text {th }}$ Hawaii International Conference on Systems Sciences, IEEE. Available at http://www.uni-potsdam.de/u/governance/Doktoranden/Stieglitz/22680192a.pdf (retrieved April 9, 2008)

Lerner, J. \& Tirole, J. 2001. The Open Source movement: key research questions. European Economic Review. 45: 819-826. 
Lerner, J. \& Tirole, J. 2002. Some simple economics of Open Source. The Journal of Industrial Economics. L (2): 197-234.

Liang, L. 2007. Free/Open Source Software Open Content. Thailand. United Nations development programme- Asia-Pacific development information programme

Lynn, L., Heinrich, C. \& Hill, C. 2001. Improving governance: a new logic for empirical research. Washington, D.C.: Georgetown University Press.

Markus, L. 2007. The governance of free/open source software projects: monolithic, multidimensional or configurationally?. Journal Manage Governance, 11:151163

Mehegan, D. 2006. Many contributors, common cause. Wikipedia volunteers share conviction of doing good for society. The Boston Globe. Available at http://www.boston.com/business/technology/articles/2006/02/13/many_contributo rs_common_cause/ (retrieved February 23, 3008)

Miles, M. \& Huberman, M. 1994. Qualitative data analysis. An expanded source book. Beverly Hills, SAGE Publications, Inc.

Mintzbert, H. 1979. The structuring of organizations. Englewood Cliffs, N.J.: PrenticeHall.

Mora, M. 2007. Open Educational Resources. Open Source Business Resource. September issue. Available at http://www.osbr.ca/ojs/index.php/osbr/article/view/380/341 (retrieved February $15,2008)$

Nichols, D. \& Twidale, M. 2003. The Usability of Open Source Software. First Monday, Peer-Reviewed Journal on the Internet, 8(1) Available at http://firstmonday.org/issues/issue8_1/nichols/index.html (retrieved January 19, 2008)

Organization for Economic Co-operation and Development, 2007. Giving knowledge for free. The emergence of open educational resources. Paris, OECD publishing. Available at http://www.oecd.org/document/41/0,3343,en_2649_33723_38659497_1_1_1_1,0 0.html (retrieved June 21, 2007)

Ogbuji, U. 2007. Real Web 2.0: Wikipedia, champion of user generated content. Developer Work. IBM's resource for developers. Available at http://www.ibm.com/developerworks/web/library/wa-realweb4/index.html (retrieved February 22, 2008)

O'Mahony, S. 2007. Governance of open source initiatives: what does it mean to be community managed? Journal Manage Governance, 11:139-150 
O'Mahony, S. 2003. Guarding the commons: how community managed software projects protect their work. Research Policy, 32:1179-1198.

Organization: MIT OpenCourseWare approach 2008. "OpenCourseWare how to" website. Available at http://ocw.mit.edu/OcwWeb/HowTo/OrgMITApproach.htm (retrieved February 23, 2008)

Open Source Initiative (OSI). 2008. Definition of Open Source. Available at $\mathrm{http} / / / \mathrm{www}$. opensource.org/ (retrieved January 29, 2008)

Ostero, M. \& Rota, S. 2007. Open source software development - just another case of collective invention? Research Policy. 36:157-171

Parker, P. 2007. Open Content in Education: the instructor benefits of OpenCourseWare. In proceedings of Open Education 2007: Localizing and learning. Began, UT. pp $159-160$

Phelps, M. 2006. Tuftus University. A case study on production and use of open education resources. October, OECD. Available at http://www.oecd.org/dataoecd/61/47/37647678.pdf (retrieved March 27, 2008)

Remmele, B. 2006. Open Educational Resources - Anonymity vs. Specificity. European Journal of Open Distance and E-learning. Available at http://www.eurodl.org/materials/contrib/2006/Bernd_Remmele.htm (retrieved April 12, 2008)

Report of the discussion on Free and Open Source Software (FOSS) for Open Educational Resources. 2006. International community of interest, Open Educational Resources, open content for higher education UNESCO-IIEP. Available at http://oerwiki.iiepunesco.org/index.php?title=FOSS_solutions_for_OER_-_summary_report (retrieved June 25, 2007)

Rominger, R. \& Lopez, G. 2007. Key features of a sustainable model for collaborative content development. In proceedings of Open Education 2007: Localizing and learning. Began, UT. pp 179-180

Sack, W., Detienne, F., Ducheneaut, N., Burkhardt, J., Mahendran, D. \& Barcellini, F. 2006. A methodological framework for socio-cognitive analyses of collaborative design of open source. Computer Supported Cooperative Work (CSCW), 15(23): 229-250.

Stacey, P. 2007. Open Educational Resources in a global context. First Monday, PeerReviewed Journal on the Internet, 12(4) Available at $\mathrm{http} / / /$ www.firstmonday.org/issues/issue12_4/stacey/index.html (retrieved February 27, 2008)

Schmidt, P. 2008. UNESCO OER Toolkit Draft. Wiki Educator, free elearning content. 
Available at http://www.wikieducator.org/UNESCO_OER_Toolkit_Draft (retrieved February 20, 2008).

Tuomi, I. 2006. Open Educational Resources: what they are and why do they matter. Report prepared for the OECD. Available at http://www.meaningprocessing.com/personalPages/tuomi/articles/OpenEducation alResources_OECDreport.pdf (retrieved April 12, 2008)

Udas, K., Wyles, R., Mackintosh, W., Masson, P., Tucker, K., Dalzell, J., Mashayekh, F., Perue, C., Dauphin, J.C., Hancock, M., \& Moore, D. 2007 Overview of the OSS and OER in Education Series. PennState World Campus. Terra Incognita. Available at http://wikieducator.org/Overview_of_the_OSS_and_OER_in_Education_Series

von Hippel, E. \& von Krogh, G. 2003. Open Source Software and the "private collective" innovation model. Organization Science. 14(2): 209-223

von Krogh, G. \& von Hippel, E. 2006. The promise of research on Open Source Software. Management Science. 52(7): 975-983

von Krough, G., Spaeth, S. \& Lakhani, K. 2003. Community, joining, and specialization in open source software innovation: a case study. Research Policy, 32: 12171241.

Wikieducator main page, 2008. The purpose of Wikieducator. Available at http://www.wikieducator.org/Main_Page (retrieved July 14, 2008)

Wikipedia, 2008. Article about Wikipedia, the free encyclopedia. Available at http://en.wikipedia.org/wiki/Wikipedia (retrieved February 22, 2008)

Wiley, D. 2006. The current state of Open Educational Resources. Iterating toward openness. Available at http://opencontent.org/blog/archives/247 (retrieved January 26,2007$)$

Yang, J. 2006. Sales generated using open source software projects. Unpublished master dissertation. Carleton University, Ottawa.

Yin, R. K. 1989. Case study research design and methods (revised edition). California: SAGE Publications, In 


\section{Appendix A Initial list of OER projects}

\section{A.1 List of OER projects that utilize the producer-consumer model for content development}

\begin{tabular}{|c|c|c|c|c|}
\hline No & Project's name & Website & Year & $\begin{array}{c}\text { Institution that } \\
\text { established the } \\
\text { project } \\
\end{array}$ \\
\hline 1 & $\begin{array}{l}\text { Capilano College } \\
\text { OCW }\end{array}$ & ocw.capcollege.bc.ca/ & 2007 & Capilano College \\
\hline 2 & $\begin{array}{l}\text { Chinese Quality } \\
\text { OCW }\end{array}$ & ocw.core.org.cn/CORE & 2006 & $\begin{array}{l}\text { China Open } \\
\text { Resources for } \\
\text { Education, CORE }\end{array}$ \\
\hline 3 & $\begin{array}{l}\text { Free Courseware } \\
\text { project, University } \\
\text { of Western Cape }\end{array}$ & freecourseware.uwc.ac.za & 2005 & $\begin{array}{l}\text { University of Western } \\
\text { Cape }\end{array}$ \\
\hline 4 & $\begin{array}{l}\text { Japan OCW } \\
\text { alliance }\end{array}$ & jocw.jp/ & 2005 & $\begin{array}{l}\text { Six Japanese } \\
\text { universities }\end{array}$ \\
\hline 5 & $\begin{array}{l}\text { Johns Hopkins } \\
\text { Bloomberg School } \\
\text { of Public Health's } \\
\text { OCW }\end{array}$ & ocw.jhsph.edu & 2005 & $\begin{array}{l}\text { Jhons Hopkins } \\
\text { Bloomberg School of } \\
\text { Public Health }\end{array}$ \\
\hline 6 & MIT OCW & ocw.mit.edu & 2002 & $\begin{array}{l}\text { Massachusetts } \\
\text { Institute of } \\
\text { Technology } \\
\end{array}$ \\
\hline 7 & $\begin{array}{l}\text { National } \\
\text { Repository of } \\
\text { Online Courses } \\
\text { (NROC) }\end{array}$ & montereyinstitute.org/nroc & 2004 & $\begin{array}{l}\text { Monterrey Institute } \\
\text { for Technology and } \\
\text { Education }\end{array}$ \\
\hline 8 & $\begin{array}{l}\text { Open Learning } \\
\text { Initiative (OLI) }\end{array}$ & cmu.edu/oli/ & 2006 & $\begin{array}{l}\text { Carnegie Mellon } \\
\text { University }\end{array}$ \\
\hline 9 & Open Yale courses & open.yale.edu/courses & 2008 & Yale University \\
\hline 10 & Sofia & sofia.fhda.edu & 2004 & Foothill College \\
\hline 11 & TU Delft & ocw.tudelft.nl/home & 2007 & $\begin{array}{l}\text { Delft University of } \\
\text { Technology }\end{array}$ \\
\hline 12 & $\begin{array}{l}\text { Tufts University } \\
\text { OCW }\end{array}$ & ocw.tufts.edu & 2005 & Tufts University \\
\hline 13 & UC Irvine OCW & ocw.uci.edu & 2007 & $\begin{array}{l}\text { University of } \\
\text { California, Irvine } \\
\end{array}$ \\
\hline
\end{tabular}




\begin{tabular}{|l|l|l|l|l|}
\hline 14 & $\begin{array}{l}\text { UMass Boston } \\
\text { OCW }\end{array}$ & ocw.umb.edu & 2005 & UMass Boston \\
\hline 15 & $\begin{array}{l}\text { United Nations } \\
\text { University OCW }\end{array}$ & ocw.unu.edu/ & 2008 & $\begin{array}{l}\text { United Nations } \\
\text { University }\end{array}$ \\
\hline 16 & $\begin{array}{l}\text { Universidad de } \\
\text { Monterrey OCW }\end{array}$ & ocw.udem.edu.mx/ & 2008 & $\begin{array}{l}\text { Universidad de } \\
\text { Monterrey }\end{array}$ \\
\hline 17 & $\begin{array}{l}\text { University of } \\
\text { Notre Dame OCW }\end{array}$ & ocw.nd.edu/ & 2006 & $\begin{array}{l}\text { University of Notre } \\
\text { Dame }\end{array}$ \\
\hline $\mathbf{1 8}$ & $\begin{array}{l}\text { Webcast Berkeley } \\
\text { Webcast.berkeley.edu }\end{array}$ & 2002 & $\begin{array}{l}\text { University of } \\
\text { California }\end{array}$ \\
\hline
\end{tabular}




\section{A.2 List of OER projects that use the co-production model for content development}

\begin{tabular}{|c|c|c|c|c|}
\hline No & OER project & Website & Year & Institution \\
\hline 1 & Connexions & cnx.org & 1999 & Rice University \\
\hline 2 & Curriki & curriki.org & 2006 & $\begin{array}{l}\text { Global education and } \\
\text { learning community } \\
\text { (GELC) }\end{array}$ \\
\hline 3 & LeMill & lemill.net & 2007 & $\begin{array}{l}\text { Media Lab, University } \\
\text { of Art and Design } \\
\text { Helsinki }\end{array}$ \\
\hline 4 & $\begin{array}{l}\text { New Zealand } \\
\text { OER project }\end{array}$ & repository.ac.nz & 2007 & $\begin{array}{l}\text { New Zealand's } \\
\text { Tertiary Education } \\
\text { Commission's } \\
\text { Innovation } \\
\text { Development Fund } \\
\text { (ECDF) }\end{array}$ \\
\hline 5 & OpenLearn & openlearn.open.ac.uk & 2005 & The Open University \\
\hline 6 & WikiEducator & wikieducator.org & 2006 & $\begin{array}{l}\text { Commonwealth of } \\
\text { Learning }\end{array}$ \\
\hline 7 & Wikipedia & wikipedia.org & 2001 & Wikimedia foundation \\
\hline 8 & Wikiversity & en.wikiversity.org/ & 2006 & $\begin{array}{l}\text { Wikimedia } \\
\text { Foundation }\end{array}$ \\
\hline
\end{tabular}




\section{Appendix B Initial codes for categorizing motives for establishing OER projects}

\begin{tabular}{|l|l|}
\hline \multicolumn{1}{|c|}{ Motives } & \multicolumn{1}{c|}{ Codes } \\
\hline $\begin{array}{l}\text { Public relations and attract } \\
\text { future students }\end{array}$ & $\begin{array}{l}\text { Present content developed by the institution, attract } \\
\text { students }\end{array}$ \\
\hline Ethical reasons & Improve access to education, help \\
\hline Cost reduction & Reduce cost, savings \\
\hline $\begin{array}{l}\text { Create alternatives to } \\
\text { proprietary materials }\end{array}$ & Reduce dependence on commercial textbooks \\
\hline $\begin{array}{l}\text { Experiment with new } \\
\text { business models }\end{array}$ & Business models, revenue \\
\hline Encouraging innovation & Foster innovation, collaborative content production \\
\hline $\begin{array}{l}\text { Quality enhancement and } \\
\text { diversity }\end{array}$ & Improve quality, diversity \\
\hline Leverage taxpayer's money & Leverage, taxpayer's, publicly funded \\
\hline
\end{tabular}




\section{Appendix C Motives for establishing OER projects and their references}

\begin{tabular}{|c|c|}
\hline OER project & Motives for establishing the project \\
\hline MIT OCW & $\begin{array}{l}\text { Provide an instrument for realization of faculty goals, stimulating } \\
\text { innovation and, countering the privatization of knowledge and } \\
\text { champions the movement toward greater openness for the benefit } \\
\text { of society }\end{array}$ \\
\hline Tufts & $\begin{array}{l}\text { Support and advance education by making high-quality content } \\
\text { freely available on the Web for learners and faculty across the } \\
\text { nation and the world } \\
\text { - Continue Tufts' tradition of knowledge sharing as part of its non- } \\
\text { profit mission and as part of Tufts leadership in civic engagement } \\
\text { - Promote collaboration by bringing faculty and courses from } \\
\text { various disciplines together in one location, and by drawing on } \\
\text { staff and resources from across the University for } \\
\text { implementation }\end{array}$ \\
\hline Connexions & $\begin{array}{l}\text { - Make available the worlds' knowledge to everyone }{ }^{20} \\
\text { - Connexions was created to reinvent how we write, edit, publish, } \\
\text { and use textbooks and other learning materials } \\
\end{array}$ \\
\hline WikiEducator & $\begin{array}{l}\text { Encourage the development and sharing of open and distance } \\
\text { education knowledge, resources and technologies }\end{array}$ \\
\hline OLI & $\begin{array}{l}\text { - Aims to increase access to education, enhancing the quality of } \\
\text { instruction and providing a model for a new generation of online } \\
\text { courses and course materials that teach more effectively and appeal } \\
\text { to students more powerfully than anything in existence today }{ }^{23}\end{array}$ \\
\hline
\end{tabular}

\footnotetext{
${ }^{15} \mathrm{http}: / /$ ocw.mit.edu/ans7870/global/05_Prog_Eval_Report_Final.pdf

${ }^{16} \mathrm{http} / / /$ ocw.tufts.edu/Help

${ }^{17} \mathrm{http}: / /$ ocw.tufts.edu/Help

${ }^{18} \mathrm{http} / / /$ ocw.tufts.edu/Help

${ }^{19}$ http://ocw.tufts.edu/Help

${ }^{20}$ Interview with the Director of Connexions, June 27, 2008

${ }^{21} \mathrm{http} / / / \mathrm{www} . d \mathrm{sp} . e c e . r i c e . e d u / \% 7$ Erichb/Connexions-FAQ-november07.pdf

${ }^{22} \mathrm{http} / /$ www.wikieducator.org/WikiEducator:Multimedia/Our_project

${ }^{23} \mathrm{http}: / /$ www.cmu.edu/oli/overview/index.html
} 


\begin{tabular}{|c|c|}
\hline TU Delft & $\begin{array}{l}\text { - Aims to support and advance education by making high-quality } \\
\text { content freely available on the Web for learners and faculty across } \\
\text { the nation and the world } \\
\text { - Sharing of knowledge and further development of international } \\
\text { networks } \\
\text { - Inform potential students about the courses offered by TU Delft }{ }^{26}\end{array}$ \\
\hline LeMill & Data not available in the project website \\
\hline Curriki & $\begin{array}{l}\text { Motivated by the idea that technology can play a crucial role in } \\
\text { breaking down the barriers of the Education Divide - the gap } \\
\text { between those who have access to high-quality education and those } \\
\text { who do not }\end{array}$ \\
\hline Sofia & $\begin{array}{l}\text { Established the OER project for publication and free exchange of } \\
\text { community college-level course materials on the World Wide } \\
\mathrm{Web}^{27}\end{array}$ \\
\hline NROC & $\begin{array}{l}\text { Addressing the needs of underserved students, helping establish } \\
\text { content and technical standards for online content, collaboration } \\
\text { among content developers and users and supporting the OER } \\
\text { movement }^{28}\end{array}$ \\
\hline OpenLearn & - Aims to open access to education for all ${ }^{29}$ \\
\hline Wikiversity & $\begin{array}{l}\text { Aims to further the discovery and distribution of knowledge in a } \\
\text { very natural way, by helping people to learn and to share learning } \\
\text { resources }\end{array}$ \\
\hline
\end{tabular}

\footnotetext{
${ }^{24} \mathrm{http} / / /$ ocw.tudelft.nl/about-opencourseware/help-faq/

${ }^{25} \mathrm{http}: / / \mathrm{ocw}$.tudelft.nl/about-opencourseware/help-faq/

${ }^{26} \mathrm{http}: / / \mathrm{ocw}$.tudelft.nl/about-opencourseware/help-faq/

${ }^{27} \mathrm{http} / / /$ sofia.fhda.edu/faqs.htm

${ }^{28}$ Rominger \& Lopez, 2007

${ }^{29} \mathrm{http} / /$ www.open.ac.uk/openlearn/about-us/our-story.php\#1
} 
Appendix D Final codes and phrases for categorizing motives for establishing OER projects

\begin{tabular}{|l|l|}
\hline \multicolumn{1}{|c|}{ Motive } & \multicolumn{1}{|c|}{ Codes } \\
\hline $\begin{array}{l}\text { Increase access and free exchange of } \\
\text { educational content worldwide }\end{array}$ & $\begin{array}{l}\text { Benefit, advance, increase access, education, } \\
\text { education for all, underserved students, bridge } \\
\text { digital divide, knowledge, share, free, exchange }\end{array}$ \\
\hline $\begin{array}{l}\text { Promote collaboration among faculty } \\
\text { and/or content developers }\end{array}$ & Collaboration, faculty, content developers \\
\hline $\begin{array}{l}\text { Stimulate innovation around content } \\
\text { development and online instruction }\end{array}$ & Innovation, new ways, new model \\
\hline Interact with a global community & Global, international, community \\
\hline Enhance quality of teaching & Enhance, teaching, faculty goals \\
\hline Counter privatization of knowledge & Counter, privatization \\
\hline $\begin{array}{l}\text { Showcase their courses to potential } \\
\text { students }\end{array}$ & Inform students \\
\hline $\begin{array}{l}\text { Help to set standards for online } \\
\text { content }\end{array}$ & Set standards, help to \\
\hline $\begin{array}{l}\text { Increase the pool of online learning } \\
\text { materials }\end{array}$ & development, learning materials \\
\hline Support the OER movement & Support OER movement \\
\hline
\end{tabular}


Appendix E Information used to collect the data on five governance dimensions

\begin{tabular}{|c|c|}
\hline $\begin{array}{c}\text { OER } \\
\text { project }\end{array}$ & Information on governance dimensions \\
\hline $\begin{array}{l}\text { MIT } \\
\text { OCW }\end{array}$ & $\begin{array}{l}\text { Organizational structure } \\
\text { MIT OCW has a publishing team composed of } 11 \text { people divided } \\
\text { into } 4 \text { teams. Each team covers a range of academic departments } \\
\text { at MIT. Each team is composed of one publication manager and } \\
\text { one or two publication liaisons } \\
\text { Participation of volunteer contributors } \\
\text { Volunteer contributors are not allowed in the MIT OCW. The } \\
\text { intent of MIT OCW is that the site should reflect the materials } \\
\text { used in courses taught at MIT. The materials presented on the } \\
\text { MIT OCW site are authored by members of the MIT faculty, and } \\
\text { they take final responsibility for these materials } \\
\text { Partnerships } \\
\text { Total of seven found in the website } \\
\text { For sponsorship } \\
\text { - One corporation } \\
\text { - Four foundations } \\
\text { Others } \\
\text { - One network of OCW projects around the world: OCW } \\
\text { - Consortium } \\
\text { One organization for translation of courses: Santander } \\
\text { License } \\
\text { CC, BY-NC-SA* } \\
\text { Core mission } \\
\text { OCW has a dual mission: } \\
\text { - Provide free access to virtually all MIT course materials for } \\
\text { educators, students, and individual learners around the world } \\
\text { Extend the reach and impact of MIT OCW and the OCW } \\
\text { concept }\end{array}$ \\
\hline
\end{tabular}

* CC- Creative Commons, BY- Attribution, NC- Non commercial, SA- Share alike 


\begin{tabular}{|c|c|}
\hline Tufts & $\begin{array}{l}\text { Organizational structure } \\
\text { Faculty is supported by the Tufts University Sciences } \\
\text { Knowledgebase (TUSK) staff to develop and publish their } \\
\text { courses as OCW } \\
\text { Participation of volunteer contributors } \\
\text { The intent of Tufts OCW is that our website should reflect the } \\
\text { course materials being taught at Tufts } \\
\text { Partnerships } \\
\text { Total of seven found in the website } \\
\text { Sponsorship } \\
\text { Three foundations } \\
\text { Others } \\
\text { - Three African institutions: to share curriculum } \\
\text { - One network of OCW projects around the world: OCW } \\
\text { Consortium } \\
\text { Licenses } \\
\text { CC, BY-NC-SA } \\
\text { Core mission } \\
\text { Support and advance education by making high-quality content } \\
\text { freely available on the Web for learners and faculty across the } \\
\text { nation and the world }\end{array}$ \\
\hline $\begin{array}{c}\text { Connexio } \\
\text { ns }\end{array}$ & $\begin{array}{l}\text { Organizational structure } \\
\text { Authors input text, images, and sounds into Connexions. } \\
\text { Instructors arrange the author input into courses. Students or } \\
\text { anyone view the course material to gain knowledge } \\
\text { Participation of volunteer contributors } \\
\text { Connexions was designed to be globally accessible to anyone to } \\
\text { read and use their materials and also take them, modify them, and } \\
\text { contribute them back to the repository } \\
\text { Partnerships } \\
\text { Total of seven found in the website } \\
\text { Sponsorship } \\
\text { - Five foundations } \\
\text { - Two companies } \\
\text { License } \\
\text { CC-BY } \\
\text { Core mission } \\
\text { Make available the world's knowledge to everyone }\end{array}$ \\
\hline
\end{tabular}




\begin{tabular}{|c|l|}
\hline Wiki & $\begin{array}{l}\text { Organizational structure } \\
\text { Contributors can create learning content directly, by entering a } \\
\text { lesson plan and activities onto a WikiEducator page } \\
\text { Participation of volunteer contributors } \\
\text { Anyone can create an account in WikiEducator and contribute } \\
\text { their educational materials to the repository } \\
\text { Partnerships } \\
\text { Total of five found in the website } \\
\text { For content development } \\
\text { Two non profit organizations: Learning4content, Virtual } \\
\text { University for Small States of the Commonwealth } \\
\text { One university: Otago Polytechnic University } \\
\text { One college: St Michaels College } \\
\text { One consortium: Open eLearning Content Observatory } \\
\text { Services (OLCOS) } \\
\text { Licenses } \\
\text { Content in Wikieducator is licensed either under s CC-BY-SA } \\
\text { license or CC-BY license } \\
\text { Core mission } \\
\text { Build a thriving and sustainable global community dedicated to } \\
\text { the design, development and delivery of free content for learning } \\
\text { in realisation of a free version of the education curriculum by } \\
\text { 2015 }\end{array}$ \\
\hline
\end{tabular}




\begin{tabular}{|c|c|}
\hline OLI & $\begin{array}{l}\text { Organizational structure } \\
\text { Data not available } \\
\text { Participation of volunteer contributors } \\
\text { Courses are developed in a modular fashion to allow faculty at a } \\
\text { variety of institutions to either deliver the courses as designed or } \\
\text { to modify the content and sequence to fit the needs of their } \\
\text { students and/or their curricular and course goals. These courses } \\
\text { will be broadly disseminated at no cost to individual students and } \\
\text { at low cost to institutions } \\
\text { Partnerships } \\
\text { One found in the website } \\
\text { For sponsorship } \\
\text { - One foundation: The William and Flora Hewlett Foundation } \\
\text { License } \\
\text { CC, BY-NC-SA } \\
\text { Core mission } \\
\text { Create courses that enact instruction that is, to create complete } \\
\text { online courses from which learners can learn even if they do not } \\
\text { have benefit of an instructor or a class }\end{array}$ \\
\hline TU Delft & $\begin{array}{l}\text { Organizational structure } \\
\text { Data not available } \\
\text { Participation of volunteer contributors } \\
\text { The intent of TU Delft OCW is that our website should reflect the } \\
\text { course materials being taught at TU Delft. Therefore volunteer } \\
\text { contributors are not allowed } \\
\text { Partnerships } \\
\text { One found in the website } \\
\text { - One network of OCW projects around the world: OCW } \\
\text { Consortium } \\
\text { License } \\
\text { CC, BY-NC-SA } \\
\text { Core mission } \\
\text { Support and advance education by making high-quality content } \\
\text { freely available on the Web for learners and faculty across the } \\
\text { nation and the world }\end{array}$ \\
\hline
\end{tabular}




\begin{tabular}{|c|c|}
\hline LeMill & $\begin{array}{l}\text { Organizational structure } \\
\text { Anyone may edit content and combine larger chunks of learning } \\
\text { resources from individual media pieces } \\
\text { Participation of volunteer contributors } \\
\text { Anyone can add their own learning content to LeMill } \\
\text { Partnerships } \\
\text { Six found in the website } \\
\text { For sponsorship } \\
\text { - One organization: European Information Society } \\
\text { Technologies program } \\
\text { For software development } \\
\text { - Four networks of developers: from Finland, Estonia, Hungary } \\
\text { and Norway } \\
\text { Others } \\
\text { - One initiative: European Schoolnet's Learning Resource } \\
\text { Exchange initiative } \\
\text { License } \\
\text { CC, BY-SA } \\
\text { Core mission } \\
\text { Data not available }\end{array}$ \\
\hline Curriki & $\begin{array}{l}\text { Organizational structure } \\
\text { Contributors can select and modify existing content } \\
\text { to shape their own customized online course or complete textbook } \\
\text { Participation of volunteer contributors } \\
\text { Anyone can contribute educational materials to Curriki } \\
\text { Partnerships } \\
\text { Thirty one found in the website } \\
\text { The Curriki's site lists } 31 \text { companies and non profit organizations } \\
\text { as partners } \\
\text { License } \\
\text { CC, BY is used by default when the materials are created. } \\
\text { However, any other CC license can be selected by the authors } \\
\text { Core mission } \\
\text { Support the development and free distribution } \\
\text { of open source educational materials to improve education } \\
\text { worldwide }\end{array}$ \\
\hline
\end{tabular}




\begin{tabular}{|c|c|}
\hline Sofia & $\begin{array}{l}\text { Organizational structure } \\
\text { Selected content is re-purposed as needed to ensure consistent } \\
\text { quality and presentation format, re-usability for a wider audience, } \\
\text { and accessibility. Dedicated staff (instructional designers) play a } \\
\text { key role in the course conversion process } \\
\text { Participation of volunteer contributors } \\
\text { Participation is voluntary and is open to faculty from community } \\
\text { colleges and four-year universities } \\
\text { Partnerships } \\
\text { One found in the website } \\
\text { For sponsorship } \\
\text { - One foundation: The William and Flora Hewlett foundation } \\
\text { License } \\
\text { CC, BY-NC unless otherwise specified by the authors } \\
\text { Core mission } \\
\text { Support and advance education by making high-quality content } \\
\text { freely available on the Web for learners and faculty across the } \\
\text { nation and the world }\end{array}$ \\
\hline NROC & $\begin{array}{l}\text { Organizational structure } \\
\text { The NROC editorial, design, and engineering teams works with } \\
\text { author groups of Network members to plan syllabi, tables of } \\
\text { content, and the presentation approach } \\
\text { Participation of volunteer contributors } \\
\text { Only people that works at institutions members of the NROC } \\
\text { network can contribute materials } \\
\text { Partnerships } \\
\text { One found in the website } \\
\text { For sponsorship } \\
\text { One foundation: The William and Flora Hewlett Foundation } \\
\text { License } \\
\text { Copyright. The content on this website is provided by the } \\
\text { Monterey Institute for Technology and Education for personal } \\
\text { enrichment and individual instructor use only } \\
\text { Core mission } \\
\text { Addresses the common need among educational institutions for } \\
\text { quality online content and professional development of faculty } \\
\text { and staff }\end{array}$ \\
\hline
\end{tabular}




\begin{tabular}{|c|c|}
\hline $\begin{array}{l}\text { Open } \\
\text { Learn }\end{array}$ & $\begin{array}{l}\text { Organizational structure } \\
\text { Authors can publish their content in the LabSpace. Faculty from } \\
\text { the Open University (OU) that supplies materials to the } \\
\text { LearningSpace have support from OU staff to publish their } \\
\text { courses } \\
\text { Participation of volunteer contributors } \\
\text { The project is divided into the LabSpace and the LearningSpace. } \\
\text { Volunteer contributors are allowed to participate in the LabSpace } \\
\text { but not in the LearnigSpace. LearningSpace reflects the courses } \\
\text { taught at the Open University } \\
\text { Partnerships } \\
\text { One found in the website } \\
\text { For sponsorship } \\
\text { - One foundation: The William and Flora Hewlett Foundation } \\
\text { License } \\
\text { CC, BY-NC-SA } \\
\text { Core mission } \\
\text { Draw on the Open University's extensive accumulation of } \\
\text { learning materials, and make them available in an international } \\
\text { web-based open content environment }\end{array}$ \\
\hline $\begin{array}{l}\text { Wiki } \\
\text { versity }\end{array}$ & $\begin{array}{l}\text { Organizational structure } \\
\text { Contributors can add their educational materials to the wiki } \\
\text { platform } \\
\text { Participation of volunteer contributors } \\
\text { Wikiversity can be used by anyone to share their knowledge } \\
\text { about a subject, and to build learning materials around that } \\
\text { knowledge } \\
\text { Partnerships } \\
\text { Data not available } \\
\text { License } \\
\text { GNU free documentation license } \\
\text { Core mission } \\
\text { Empower people to achieve their educational goals using } \\
\text { resources produced by the free culture movement }\end{array}$ \\
\hline
\end{tabular}




\section{Appendix F Codes for categorization of tactics OER projects use to protect their content}

\section{F.1 Initial codes for categorization of tactics}

\begin{tabular}{|l|l|}
\hline \multicolumn{1}{|c|}{ Tactic } & \multicolumn{1}{c|}{ Codes } \\
\hline $\begin{array}{l}\text { Licensing terms that restrict } \\
\text { proprietary appropriation }\end{array}$ & License, protect content, proprietary appropriation \\
\hline Legal and normative sanctions & Sanctions, license compliance \\
\hline Incorporate & $\begin{array}{l}\text { Set up non profit foundation, set up legal entity, } \\
\text { intellectual property holder }\end{array}$ \\
\hline $\begin{array}{l}\text { Transfer individual property } \\
\text { rights to a foundation }\end{array}$ & Transfer copyright, transfer individual property rights \\
\hline $\begin{array}{l}\text { Trademark brands and logos } \\
\text { designed to represent their } \\
\text { work }\end{array}$ & Trademark, logo \\
\hline $\begin{array}{l}\text { Assign trademarks to the } \\
\text { foundation }\end{array}$ & Foundation holds trademark, trademark owned by \\
\hline Actively protect brand & $\begin{array}{l}\text { Brand protection, co-branding, recognition for the } \\
\text { project }\end{array}$ \\
\hline
\end{tabular}




\section{Appendix G Tactics used by OER projects to protect their content and their references}

\begin{tabular}{|c|c|}
\hline OER project & Tactics used to protect their content \\
\hline MIT OCW & $\begin{array}{l}\text { Faculty retain ownership of most materials prepared for MIT } \\
\text { OpenCourseWare, following the MIT policy on textbook authorship } \\
\text { MIT retains ownership only when significant use has been made of the } \\
\text { Institute's resources }^{31} \\
\text { Three requirements users must meet to use the materials: i) } \\
\text { Noncommercial use, ii) Attribution, and iii) Share Alike } \\
\text { The Massachusetts Institute of Technology trademarks the words } \\
\text { "MIT", "Massachusetts Institute of Technology", and its logos and } \\
\text { seal }^{33} \text { " }\end{array}$ \\
\hline Tufts & $\begin{array}{l}\text { "Tufts", "Tufts University", and its logos are registered and } \\
\text { unregistered trademarks of Tufts University } \\
\text { The OCW Materials are copyrighted and are the exclusive property of } \\
\text { Tufts, a Tufts faculty member, or their respective licensors } \\
\text { Tufts OCW has chosen the following CC license option which applies } \\
\text { to most content published on the site: Attribution, Noncommercial, and } \\
\text { Share Alike. This allows for the reuse and the creation of derivative } \\
\text { works as long as attribution to the original copyright holder is given } \\
\text { and it is for non commercial purposes }{ }^{36}\end{array}$ \\
\hline
\end{tabular}

\footnotetext{
${ }^{30} \mathrm{http} / / / \mathrm{ocw} \cdot \mathrm{mit} . \mathrm{edu} / \mathrm{OcwWeb} / \mathrm{web} / \mathrm{help} / \mathrm{faq} 3 / \mathrm{index} \cdot \mathrm{htm}$

${ }^{31} \mathrm{http}: / / \mathrm{ocw} \cdot \mathrm{mit} . \mathrm{edu} / \mathrm{OcwWeb} / \mathrm{web} / \mathrm{help} / \mathrm{faq} 3 /$ index.htm

${ }^{32} \mathrm{http}: / / \mathrm{ocw} . \mathrm{mit} . \mathrm{edu} / \mathrm{OcwWeb} / \mathrm{web} / \mathrm{help} / \mathrm{faq} 3 / \mathrm{index} \cdot \mathrm{htm}$

${ }^{33} \mathrm{http}: / /$ ocw.mit.edu/OcwWeb/web/terms/terms/index.htm

${ }^{34} \mathrm{http}: / /$ ocw.tufts.edu/LegalNotices

${ }^{35} \mathrm{http}: / /$ ocw.tufts.edu/LegalNotices

${ }^{36} \mathrm{http}: / /$ ocw.tufts.edu/Help\#_2427
} 


\begin{tabular}{|c|l|}
\hline Connexions & $\begin{array}{l}\text { License Creative Commons that makes sharing, using, and even } \\
\text { changing the content free and legal, as long as you attribute the original } \\
\text { author }\end{array}$ \\
\hline WikiEducator \\
$\begin{array}{c}\text { Authors retain their copyright in Connexions, and so they retain control } \\
\text { of their materials }\end{array}$
\end{tabular}

\footnotetext{
${ }^{37}$ http://www.dsp.ece.rice.edu/\%7Erichb/Connexions-FAQnovember07.pdfhttp://www.dsp.ece.rice.edu/\%7Erichb/Connexions-FAQ-november07.pdf ${ }^{38} \mathrm{http} / /$ www.dsp.ece.rice.edu/\%7Erichb/Connexions-FAQnovember07.pdfhttp://www.dsp.ece.rice.edu/\%7Erichb/Connexions-FAQ-november07.pdf ${ }^{*}$ Creative Commons Attribution license

* Creative Commons Attribution, Share Alike license

${ }^{39} \mathrm{http}: / /$ www.wikieducator.org/FAQs\#What_Licensing_Arrangements_Does_WikiEducator_Use.3F

${ }^{40} \mathrm{http}: / / \mathrm{ocw}$.tudelft.nl/about-opencourseware/help-faq/\#c4386

${ }^{41} \mathrm{http}$ ://ocw.tudelft.nl/about-opencourseware/help-faq/\#c4386

${ }^{42} \mathrm{http}$ ://ocw.tudelft.nl/about-opencourseware/help-faq/\#c4386
} 


\begin{tabular}{|c|l|}
\hline & $\begin{array}{l}\text { If someone choose to reuse or repost TU Delft OCW materials he must } \\
\text { give proper attribution to the original TU Delft faculty author(s) and he } \\
\text { must also include a copy of the Creative Commons license used by TU } \\
\text { Delft OCW, with every copy of the TU Delft materials or the } \\
\text { derivative work he creates from it }\end{array}$ \\
TU Delft gives a definition of non commercial use of their content
\end{tabular}

\footnotetext{
${ }^{43} \mathrm{http} / / /$ ocw.tudelft.n1/about-opencourseware/help-faq/\#c4386

${ }^{44} \mathrm{http}$ ://ocw.tudelft.nl/about-opencourseware/help-faq/\#c4386

${ }^{45} \mathrm{http}: / /$ lemill.net/content/lemill-faq\#11

${ }^{46} \mathrm{http}: / /$ lemill.net/content/lemill-faq\#11

${ }^{47} \mathrm{http}: / /$ lemill.net/content/lemill-faq\#11

${ }^{48} \mathrm{http}: / /$ www.curriki.org/Xwiki/bin/view/Main/PrivacyPolicy

${ }^{49} \mathrm{http}: / /$ sofia.fhda.edu/faqs.htm

${ }^{50} \mathrm{http}: / /$ sofia.fhda.edu/faqs.htm
} 


\begin{tabular}{|c|l|}
\hline NROC & $\begin{array}{l}\text { All uses, reuse, and distribution of Sofia open content must be } \\
\text { attributed to Sofia and to the original authors as specified in the } \\
\text { Creative Commons License chosen by them }\end{array}$ \\
\hline 52 \\
\hline Opens of use: the content on this website is provided by the Monterey \\
Institute for Technology and Education for personal enrichment only. It \\
is not intended for use by educational organizations or commercial \\
vendors
\end{tabular}

\footnotetext{
${ }^{51} \mathrm{http} / / /$ sofia.fhda.edu/faqs.htm

$52 \mathrm{http}: / /$ sofia.fhda.edu/faqs.htm

${ }^{53} \mathrm{http} / / / \mathrm{www} . \mathrm{montereyinstitute.org/nrocnetwork/index.php}$

${ }^{54}$ http://www.nrocnetwork.org/nroc_commons/

${ }^{55} \mathrm{http} / /$ www.open.ac.uk/openlearn/about-us/faq-ip.php

${ }^{56} \mathrm{http} / /$ www.open.ac.uk/openlearn/about-us/faq-ip.php

${ }^{57} \mathrm{http}: / /$ www.open.ac.uk/about/thiswebsite/p2 2.shtml

${ }^{58} \mathrm{http} / / /$ en.wikiversity.org/wiki/Wikiversity:Copyrights
} 